Prepared in cooperation with the City of Pooler, Georgia

\title{
Simulated Effects of Lower Floridan Aquifer Pumping on the Upper Floridan Aquifer at Pooler, Chatham County, Georgia
}

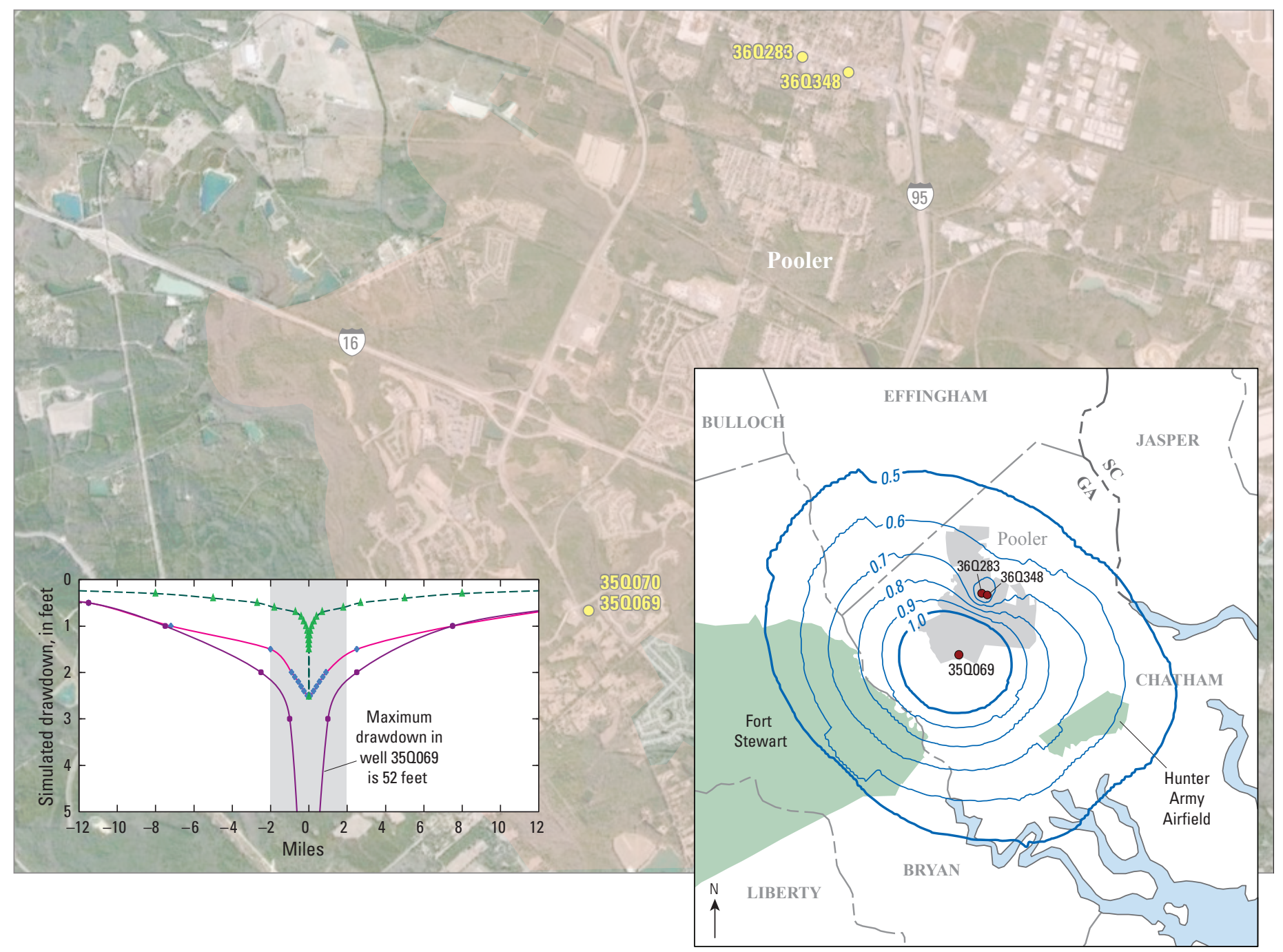

Scientific Investigations Report 2013-5004 
Cover. See report figures 1,11 , and 12 for details. 


\section{Simulated Effects of Lower Floridan Aquifer Pumping on the Upper Floridan Aquifer at Pooler, Chatham County, Georgia}

By Gregory S. Cherry and John S. Clarke

Prepared in cooperation with the City of Pooler, Georgia

Scientific Investigations Report 2013-5004 


\section{U.S. Department of the Interior \\ KEN SALAZAR, Secretary \\ U.S. Geological Survey \\ Marcia K. McNutt, Director}

U.S. Geological Survey, Reston, Virginia: 2013

For more information on the USGS - the Federal source for science about the Earth, its natural and living resources, natural hazards, and the environment, visit http://www.usgs.gov or call 1-888-ASK-USGS

For an overview of USGS information products, including maps, imagery, and publications, visit http://www.usgs.gov/pubprod

To order this and other USGS information products, visit http://store.usgs.gov

Any use of trade, product, or firm names is for descriptive purposes only and does not imply endorsement by the U.S. Government.

Although this report is in the public domain, permission must be secured from the individual copyright owners to reproduce any copyrighted materials contained within this report.

Suggested citation:

Cherry G.S., and Clarke, J.S., 2013, Simulated effects of Lower Floridan aquifer pumping on the Upper Floridan aquifer at Pooler, Chatham County, Georgia: U.S. Geological Survey Scientific Investigations Report 2013-5004, 46 p.

(Available online at http://pubs.usgs.gov/sir/2013/5004/) 


\section{Contents}

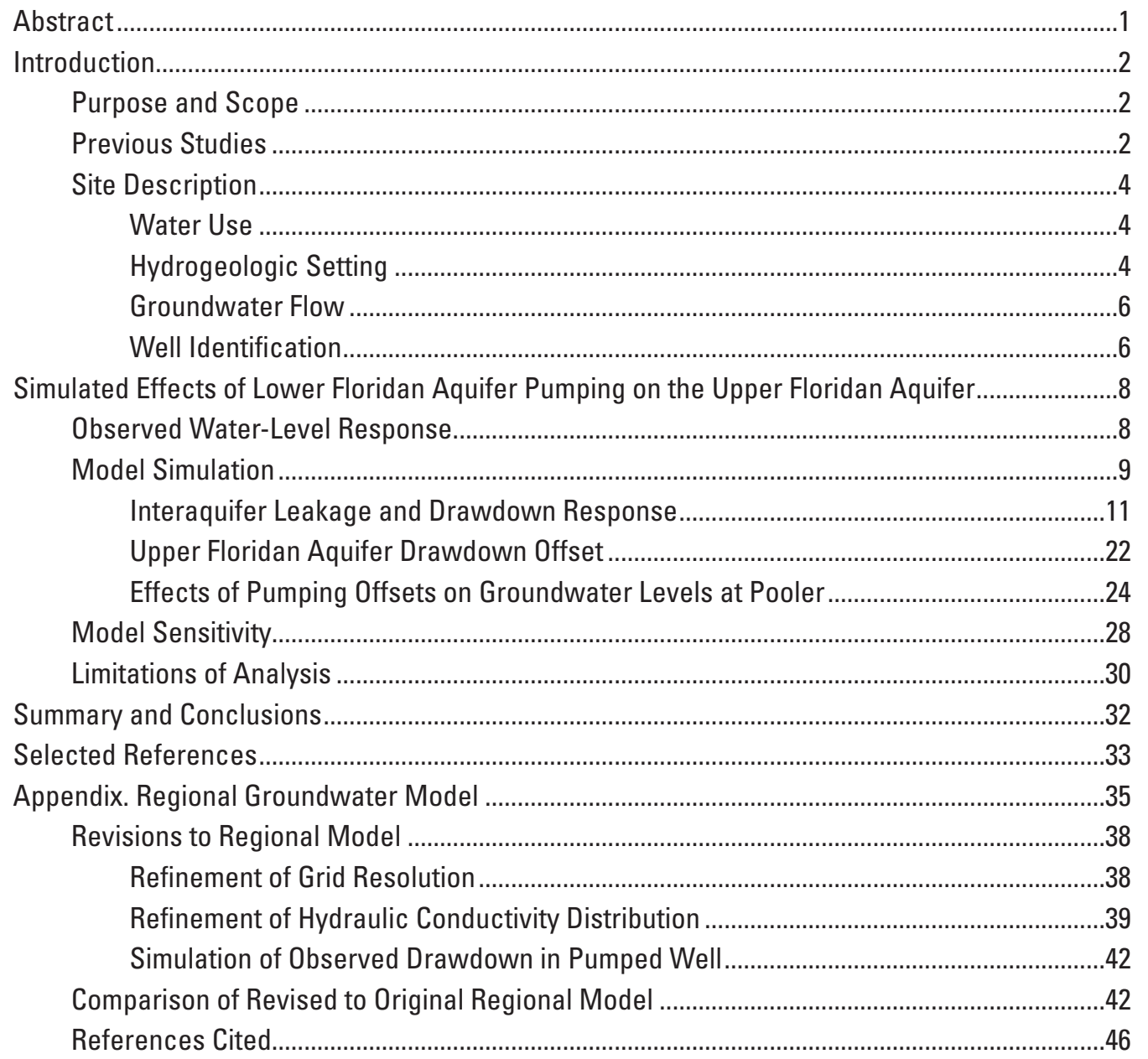




\section{Figures}

1. Maps showing location of Pooler test site (wells 350069 and 350070)

south of Pooler, Georgia .

2. Generalized correlation of geologic and hydrogeologic units and model layers in the Coastal Plain of Georgia.

3. Schematic diagram showing conceptual model of predevelopment and modern-day (2000) flow system.

4. Graphs showing water levels in wells 350069 and 350070 before, during, and after the 24-hour Upper Floridan and 72-hour Lower Floridan aquifer tests at Pooler, Georgia, March 27-May 6, 2012.

5. Maps showing simulated steady-state drawdown in the Lower Floridan aquifer for scenario A-pumping Lower Floridan aquifer well 350069 at 780 gallons per minute, Pooler and vicinity, Georgia

6. Maps showing simulated steady-state drawdown in the Upper Floridan aquifer for scenario A-pumping Lower Floridan aquifer well 350069 at 780 gallons per minute, Pooler and vicinity, Georgia

7. Maps showing distribution of interaquifer leakage from the Upper Floridan aquifer for scenario A-lower Floridan aquifer well 350069 pumping at a rate of 780 gallons per minute, Pooler and vicinity, Georgia

8. Maps showing simulated steady-state drawdown for scenario B-pumping Lower Floridan aquifer well 350069 at 1,042 gallons per minute, Pooler and vicinity, Georgia-

$8 A$. In the Lower Floridan aquifer. 16

8B. In the Upper Floridan aquifer

9. Maps showing simulated steady-state drawdown for scenario $\mathrm{C}$ - pumping Lower Floridan aquifer well 350069 at 390 gallons per minute, Pooler and vicinity, Georgia-

9A. In the Lower Floridan aquifer.

9B. In the Upper Floridan aquifer

10. Graphs showing simulated maximum drawdown in the Upper and Lower Floridan aquifers for scenarios A, B, and C, Pooler, Georgia.

11. Graphs showing simulated drawdown in the Upper Floridan aquifer for scenarios A and D, and in the Lower Floridan aquifer for scenario A, Pooler and vicinity, Georgia.

12. Map showing simulated drawdown in the Upper Floridan aquifer for scenario $\mathrm{G}$ pumping Lower Floridan aquifer well 350069 at a rate of 780 gallons per minute and reducing pumping from existing Pooler Upper Floridan aquifer wells by 255 gallons per minute.

13. Map showing simulated drawdown in the Upper Floridan aquifer for scenario $\mathrm{H}-$ pumping Lower Floridan aquifer well 350069 at a rate of 1,042 gallons per minute and reducing pumping from existing Pooler Upper Floridan aquifer wells by 340 gallons per minute.

14. Map showing simulated drawdown in the Upper Floridan aquifer for scenario pumping Lower Floridan aquifer well 350069 at a rate of 390 gallons per minute and reducing pumping from existing Pooler Upper Floridan aquifer wells by 128 gallons per minute.

15. Maps showing simulated Upper Floridan aquifer potentiometric surfaces for year 2000 and scenarios G, H, and I, Pooler and vicinity, Georgia 
16-18. Graphs showing sensitivity of simulated maximum drawdown in the Upper and Lower Floridan aquifers and simulated net flow from specified-head and general head boundaries, and between the Lower Floridan confining unit and Lower Floridan aquifer to changes in horizontal hydraulic conductivity of the-

16. Lower Floridan aquifer in hydraulic-property zone LF2 ........................................29

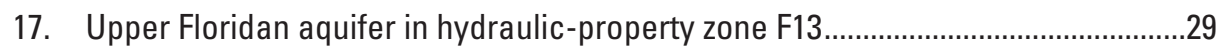

18. Lower Floridan aquifer in hydraulic-property zone LFC2 …....................................30

\section{Appendix Figures}

1-1. Maps showing location of selected wells, regional groundwater model and boundary conditions, and revised model grid, City of Pooler, Fort Stewart, and vicinity, Georgia .36

1-2. Schematic diagram showing model layers and boundary conditions ............................38

1-3. Maps showing simulated hydraulic-property zones by model layer .................................40

1-4. Maps showing difference between simulated and observed water levels (residuals) by model layer for 2000, revised regional flow model: Brunswick aquifer system (layer 3), Upper Floridan aquifer (layer 5), Lower Floridan aquifer (layer 7)

1-5. Graphs showing observed and simulated water levels in model layers 3, 5, and 7, revised groundwater model.

\section{Tables}

1. Description of model scenarios and simulated drawdown in the Upper and Lower Floridan aquifers for various pumping distributions at Pooler, Georgia

2. Simulated steady-state water budgets for 2000 and for scenario $A$, after pumping 780 gallons per minute (1.12 million gallons per day) at Lower Floridan aquifer well 350069, Pooler, Georgia

3. Simulated steady-state water budgets for 2000 and for scenario $B$, after pumping 1,042 gallons per minute (1.5 million gallons per day) at Lower Floridan aquifer well 350069, Pooler, Georgia

4. Simulated steady-state water budgets for 2000 and for scenario $C$, after pumping 390 gallons per minute ( 0.56 million gallons per day) at Lower Floridan aquifer well 350069, Pooler, Georgia

5. Sensitivity of simulated maximum drawdown in the Upper and Lower Floridan aquifers, and simulated groundwater flow to changes in selected hydraulic parameters

\section{Appendix Tables}

1-1. Horizontal and vertical hydraulic conductivity values assigned to hydraulic-property zones for the original (Payne and others, 2005) and revised groundwater-flow models.

1-2. Water-level calibration statistics for the original (Payne and others, 2005) and revised regional models, year 2000 simulation

1-3. Comparison of simulated water budget by model layer between the original (Payne and others, 2005) and revised regional models, year 2000 simulation . 


\section{Conversion Factors}

Inch/Pound to SI

\begin{tabular}{|c|c|c|}
\hline Multiply & By & To obtain \\
\hline \multicolumn{3}{|c|}{ Length } \\
\hline inch & 2.54 & centimeter $(\mathrm{cm})$ \\
\hline foot $(\mathrm{ft})$ & 0.3048 & meter $(\mathrm{m})$ \\
\hline mile (mi) & 1.609 & kilometer $(\mathrm{km})$ \\
\hline \multicolumn{3}{|c|}{ Area } \\
\hline square foot $\left(\mathrm{ft}^{2}\right)$ & 929.0 & square centimeter $\left(\mathrm{cm}^{2}\right)$ \\
\hline square foot $\left(\mathrm{ft}^{2}\right)$ & 0.0929 & square meter $\left(\mathrm{m}^{2}\right)$ \\
\hline square mile $\left(\mathrm{mi}^{2}\right)$ & 259.0 & hectare (ha) \\
\hline square mile $\left(\mathrm{mi}^{2}\right)$ & 2.590 & square kilometer $\left(\mathrm{km}^{2}\right)$ \\
\hline \multicolumn{3}{|c|}{ Volume } \\
\hline gallon (gal) & 3.785 & liter $(\mathrm{L})$ \\
\hline gallon (gal) & 0.003785 & cubic meter $\left(\mathrm{m}^{3}\right)$ \\
\hline gallon (gal) & 3.785 & cubic decimeter $\left(\mathrm{dm}^{3}\right)$ \\
\hline million gallons (Mgal) & 3,785 & cubic meter $\left(\mathrm{m}^{3}\right)$ \\
\hline \multicolumn{3}{|c|}{ Flow rate } \\
\hline foot per day (ft/d) & 0.3048 & meter per day $(\mathrm{m} / \mathrm{d})$ \\
\hline gallon per minute (gal/min) & 0.06309 & liter per second $(\mathrm{L} / \mathrm{s})$ \\
\hline gallon per day (gal/d) & 0.003785 & cubic meter per day $\left(\mathrm{m}^{3} / \mathrm{d}\right)$ \\
\hline million gallons per day (Mgal/d) & 0.04381 & cubic meter per second $\left(\mathrm{m}^{3} / \mathrm{s}\right)$ \\
\hline \multicolumn{3}{|c|}{ Specific capacity } \\
\hline $\begin{array}{l}\text { gallon per minute per foot } \\
[(\mathrm{gal} / \mathrm{min}) / \mathrm{ft})]\end{array}$ & 0.207 & $\begin{array}{l}\text { liter per second per meter } \\
{[(\mathrm{L} / \mathrm{s}) / \mathrm{m}]}\end{array}$ \\
\hline \multicolumn{3}{|c|}{ Hydraulic conductivity } \\
\hline foot per day (ft/d) & 0.3048 & meter per day $(\mathrm{m} / \mathrm{d})$ \\
\hline \multicolumn{3}{|c|}{ Transmissivity* } \\
\hline foot squared per day $\left(\mathrm{ft}^{2} / \mathrm{d}\right)$ & 0.0929 & meter squared per day $\left(\mathrm{m}^{2} / \mathrm{d}\right)$ \\
\hline
\end{tabular}

Vertical coordinate information is referenced to the National Geodetic Vertical Datum of 1929 (NGVD 29) or the North American Vertical Datum of 1988 (NAVD 88).

Horizontal coordinate information is referenced to North American Datum of 1983 (NAD 83).

Altitude, as used in this report, refers to distance above the vertical datum.

*Transmissivity: The standard unit for transmissivity is cubic foot per day per square foot times foot of aquifer thickness [(ft $\left.\left.\mathrm{ft}^{3} \mathrm{~d}\right) / \mathrm{ft}^{2}\right] \mathrm{ft}$. In this report, the mathematically reduced form, foot squared per day $\left(\mathrm{ft}^{2} / \mathrm{d}\right)$, is used for convenience. 


\section{Acknowledgments}

The authors thank Matt Saxon and Mark Williams of the Pooler Public Works Department for their helpful support throughout the project. Thanks also go to Harry Jue and Holmes Bell of Hussey Gay Bell \& Deyoung, Inc., who coordinated project drilling with testing activities conducted by the U.S. Geological Survey at the test site. 



\title{
Simulated Effects of Lower Floridan Aquifer Pumping on the Upper Floridan Aquifer at Pooler, Chatham County, Georgia
}

\author{
By Gregory S. Cherry and John S. Clarke
}

\section{Abstract}

A revised regional groundwater-flow model was used to assess the potential effects on the Upper Floridan aquifer (UFA) of pumping the Lower Floridan aquifer (LFA) from a new well (35Q069) located at the City of Pooler in coastal Georgia near Savannah. The spatial resolution of the original regional, steady-state, groundwater-flow model was increased to incorporate detailed hydrogeologic information resulting from field investigations at Pooler and existing wells in the area.

Simulation results using the U.S. Geological Survey finite-difference code MODFLOW indicated that long-term pumping at a rate of 780 gallons per minute (gal $/ \mathrm{min}$ ) from the LFA well 35Q069 would cause a maximum drawdown of about 2.52 feet (ft) in the UFA (scenario A). This maximum drawdown in the UFA was greater than the observed drawdown of $0.9 \mathrm{ft}$ in the 72-hour aquifer test, but this is expected because the steady-state simulated drawdown represents long-term pumping conditions. Model results for scenario A indicate that drawdown in the UFA exceeded $1 \mathrm{ft}$ over a 163-square-mile $\left(\mathrm{mi}^{2}\right)$ area. Induced vertical leakage from the UFA provided about 98 percent of the water to the LFA; the area within 1 mile of the pumped well contributed about 81 percent of the water pumped. Simulated pumping changed regional water-budget components slightly and redistributed flow among model layers, namely increasing downward leakage in all layers, decreasing upward leakage in all layers above the LFA, increasing inflow to and decreasing outflow from lateral specified-head boundaries in the UFA and LFA, and increasing the volume of induced recharge from the general head boundary to outcrop units. An additional two groundwater-pumping scenarios were run to establish that a linear relation exists between pumping rates of the LFA well 35Q069 (varied from 390 to $1,042 \mathrm{gal} / \mathrm{min}$ ) and amount of drawdown in the UFA and LFA.

Three groundwater-pumping scenarios were run to evaluate the amount of UFA pumping (128 to $340 \mathrm{gal} / \mathrm{min}$ ) that would produce maximum drawdown in the UFA equivalent to that induced by pumping the LFA well 35Q069 at rates specified in scenarios A, B, and C (390 to $1,042 \mathrm{gal} / \mathrm{min}$ ).
Scenarios in which the LFA well 35Q069 was pumped produced a larger drawdown area in the UFA than scenarios in which the UFA well was pumped to offset the maximum UFA drawdown simulated by scenarios A, B, and C.

Three additional groundwater-pumping scenarios were run to evaluate the combination of pumping reductions at existing Pooler UFA public-supply wells with the addition of pumping from the new LFA well. For each scenario, LFA well 35Q069 was pumped at different rates, and pumping at existing Pooler supply wells, located about 3.7 miles northward, was reduced according to UFA drawdown offsets (128 to $340 \mathrm{gal} / \mathrm{min}$ ) established by scenarios D, E, and F. Decreases in the magnitude and areal extent of drawdown in the UFA in response to pumping the LFA well were realized for scenarios that simulated drawdown offsets (reductions) for the existing UFA wells at Pooler when compared with the magnitude and extent of drawdown resulting from scenarios that did not simulate drawdown offsets for the existing UFA wells at Pooler (scenarios A, B, and C).

The revised model was evaluated for sensitivity by altering horizontal and vertical hydraulic conductivity in layers 5 through 7 (Floridan aquifer system) for newly established hydraulic-property zones by factors of $0.1,0.5,2.0$, and 10.0 . Results of the sensitivity analysis indicate that horizontal and vertical hydraulic conductivity of the UFA and LFA are the most important parameters in model simulations. The least sensitive parameters were the horizontal and vertical hydraulic conductivity of the Lower Floridan confining unit; changes to these parameters had little effect on simulated leakage and groundwater levels.

The revised model reasonably depicts changes in groundwater levels resulting from pumping the LFA at Pooler at a rate of $780 \mathrm{gal} / \mathrm{min}$. However, results are limited by the same model assumptions and design as the original model and placement of boundaries and type of boundary used exert the greatest control on overall groundwater flow and interaquifer leakage in the system. Simulation results have improved regional characterization of the Floridan aquifer system, which could be used by State officials in evaluating requests for groundwater withdrawal from the LFA. 


\section{Introduction}

The City of Pooler, located in Chatham County, Georgia (fig. 1), is experiencing increased demands on its limited freshwater resources derived primarily from the Upper Floridan aquifer (UFA). To alleviate the potential for saltwater intrusion in coastal Georgia, the Georgia Environmental Protection Division (GaEPD) has restricted further development of the UFA in the Chatham County area and encouraged development of alternative water sources, such as the Lower Floridan aquifer (LFA; Georgia Department of Natural Resources, 2006). Recent studies by the U.S. Geological Survey (USGS) at nearby Hunter Army Airfield indicate that the LFA may be a viable source of water supply in the Chatham County area (Clarke and others, 2010).

To assess the water-supply potential of the LFA at Pooler, Ga., the USGS, in cooperation with the City of Pooler, conducted an investigation during 2011-12 to determine the hydrogeology and water quality of the Floridan aquifer system and the potential simulated interaquifer leakage from the UFA into the LFA caused by pumping from a new production well in the LFA. The study included construction of a test well in the LFA and detailed site investigations, which are documented in a separate report (Gonthier, 2012). The focus of this report is on the groundwater-modeling analyses to quantify the interaquifer leakage from the UFA into the LFA. The simulated area is coincident with that used by Payne and others (2005), covering 42,155 square miles ( $\left.\mathrm{mi}^{2}\right)$ in Georgia and adjacent areas in South Carolina and Florida (fig. 1). Data from this investigation add to the USGS database of hydrogeologic information that collectively improves regional characterization of the Floridan aquifer system.

\section{Purpose and Scope}

This report documents results of groundwater-model simulations completed at Pooler during 2011-12 to assess the effect of LFA pumping on the UFA, specifically to

- Evaluate leakage response in a nearby well completed in the UFA to pumping from the LFA, and

- Quantify the reduction in pumping in the Upper Floridan well (or wells) that would offset leakage from the UFA into the LFA induced by pumping and mitigate drawdown in the UFA caused by pumping in the LFA.

Model simulations were completed using a modified version of a regional groundwater-flow model of coastal Georgia (Payne and others, 2005). The report includes maps showing drawdown response to pumping, ZONEBUDGET analysis of interaquifer and boundary flow, and a comparison of simulation results to the original model of Payne and others (2005).

\section{Previous Studies}

The USGS, in cooperation with the U.S. Department of the Army, investigated the Floridan aquifer system at Hunter Army Airfield, Chatham County, about 8 miles (mi) northeast of the Pooler test site (Clarke and others, 2010; Williams, 2010) and at Fort Stewart, Liberty County, about 23 mi southwest of the Pooler test site (Gonthier, 2011; Clarke and others, 2011). These studies involved field investigations to determine the hydrogeology and water quality of the Floridan aquifer system and groundwater-model simulations to assess the effect of LFA pumping on the UFA. The method of study for the Pooler test site is identical to the two earlier investigations at Hunter Army Airfield and Fort Stewart with field investigations that consisted of

- Boring a test hole and constructing a test well completed in the LFA,

- Collecting drill cuttings and borehole geophysical logs at the test well,

- Collecting core samples for analysis of vertical hydraulic conductivity $\left(\mathrm{K}_{\mathrm{v}}\right)$ and porosity,

- Completing flowmeter surveys throughout the Floridan aquifer system in the open test hole and in the completed LFA well,

- Performing slug tests in packer-isolated intervals in the open test hole within the Lower Floridan confining unit (LFCU) and in the test hole open to the entire Floridan aquifer system,

- Collecting depth-integrated water samples to assess water quality of various water-bearing zones,

- Boring and constructing an observation well completed in the UFA, and

- Completing a 24-hour (hr) aquifer test at the observation well open to the UFA and a 72-hr aquifer test at the test well open to the LFA.

Results of field investigations at the Pooler site are reported by Gonthier (2012). In addition to field investigations, the method applied for model simulations at Hunter Army Airfield and Fort Stewart was identical to that applied to the Pooler study, with similar modifications to the regional model of Payne and others (2005). Collectively, data obtained from these investigations add to the body of knowledge needed to characterize the Floridan aquifer system on a regional basis.

Miller (1986) developed a hydrogeologic framework for the Floridan aquifer system throughout its extent in Georgia, Florida, South Carolina, and Alabama. This framework was subsequently revised by Williams and Gill (2010) for eight northern coastal counties in Georgia and five coastal counties 

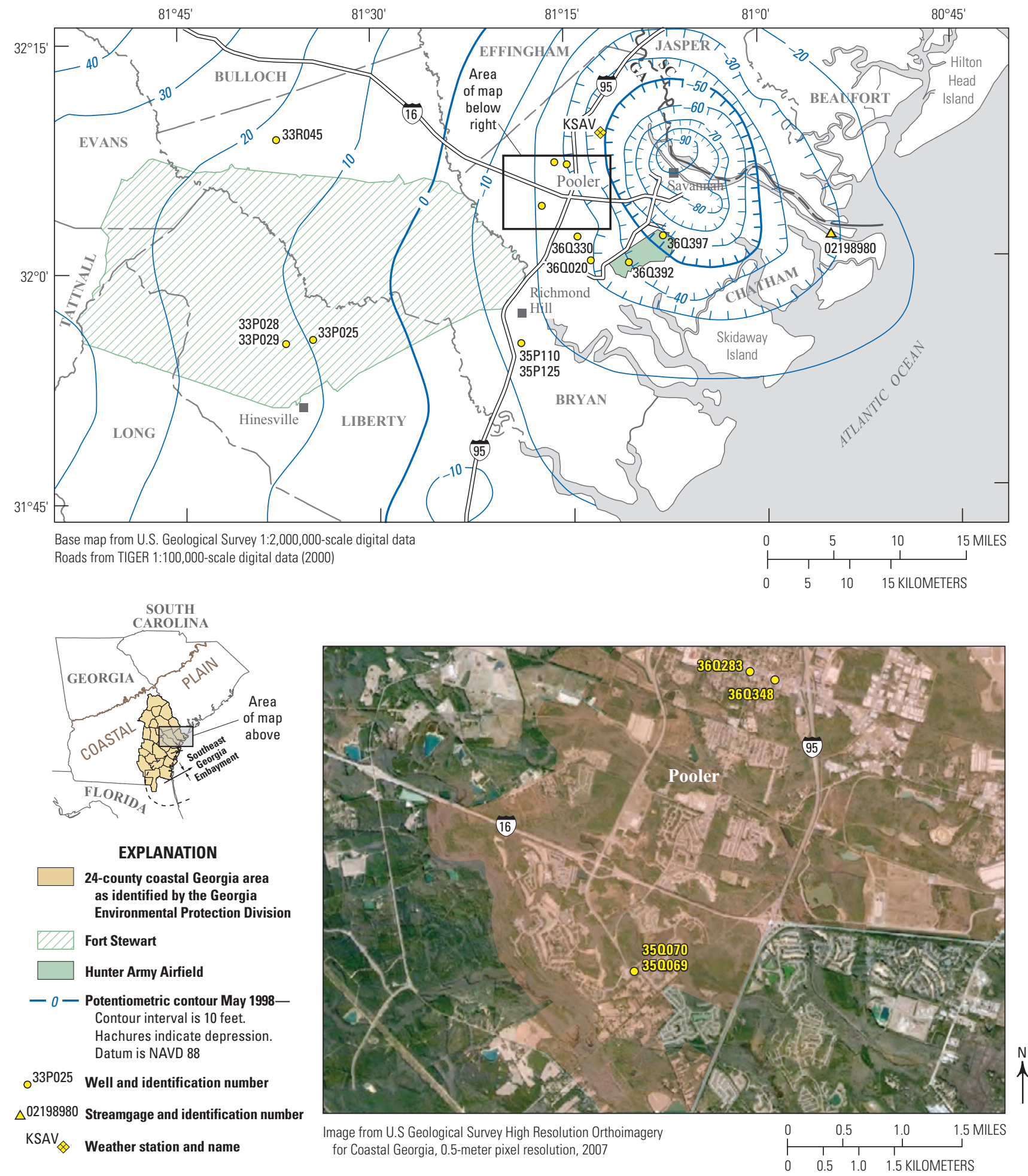

Figure 1. Location of Pooler test site (wells 350069 and 350070) south of Pooler, Georgia (from Gonthier, 2012). 
in South Carolina, including the area of the Pooler test site and test sites at Hunter Army Airfield and Fort Stewart. The Williams and Gill (2010) study used borehole geophysical and flowmeter log data collected since the original study of Miller (1986) to shift the position of internal boundaries of the Upper and Lower Floridan aquifers and of the individual permeable zones that compose these aquifers. These revised boundaries were used to guide projected drilling depths at the Pooler site.

\section{Site Description}

Pooler, Georgia, is located in the Coastal Plain physiographic province in northwestern Chatham County, Ga., near Interstate 95 (fig. 1). The site is characterized by low-altitude, flat topography, and sandy topsoil typical of the Georgia coastal area. Test drilling occurred at an altitude of about 20 feet (ft; National Geodetic Vertical Datum of 1929 [NGVD 29]). Static (non-pumping) water levels in the UFA stood at an altitude of about $-20 \mathrm{ft}$ (NGVD 29) or a depth of $40 \mathrm{ft}$ below land surface during May 1998 (Peck and others, 1999).

The study area has a mild climate with warm, humid summers and mild winters. Long-term climatic patterns in the area are derived from records provided by the National Weather Service Station at Savannah International Airport (climatological station 097847, labeled "KSAV" on fig. 1; Southeast Regional Climate Center, 2010). During 1971-2000, precipitation at station 097847 averaged about 49.6 inches per year. Maximum monthly rainfall (exceeding 4 inches per month) generally occurs during January and June-September, with monthly rainfall totals averaging less than 4 inches during the rest of the year. Mean monthly pan evaporation at station 097847 during 1965-2003 ranged from 2.43 to 8.49 inches per month, with the greatest evaporation occurring during April-August (http://www.sercc.com/cgi-bin/sercc/cliMAIN . pl?ga7847, accessed September 27, 2011).

\section{Water Use}

Water supply at Pooler is provided by two wells (36Q283 and 36Q348) completed in the Upper Floridan aquifer located about $3.6 \mathrm{mi}$ north of the test site at an average of 0.63 million gallons per day (Mgal/d) in 2005 (Fanning and Trent, 2009).

Because of concern about saltwater intrusion, the GaEPD has implemented restrictions on groundwater withdrawal from the UFA and designated management zones in coastal Georgia. Pooler is located in the GaEPD "red zone," where withdrawal from the UFA is capped at the 2004 rate. The GaEPD water-withdrawal permit for Pooler allows an annual daily average of $0.697 \mathrm{Mgal} / \mathrm{d}$ (Carol A. Couch, Director of the Georgia Environmental Protection Division, written commun., December 30, 2008).

Groundwater use in Chatham County totaled 64.97 Mgal/d during 2005 (Fanning and Trent, 2009). About half of that or $33.52 \mathrm{Mgal} / \mathrm{d}$ was for public supply. Most public-supply wells are located in the city of Savannah; additional wells to the northwest serve Pooler, Garden City, and Port Wentworth (Fanning and Trent, 2009). Payne and others (2005) estimated that during 1980-2000, nearly 95 percent of groundwater withdrawn from the county was pumped from the UFA; the remaining 5 percent was derived from the LFA. Groundwater withdrawal from the Floridan aquifer system in Chatham County increased from $79.75 \mathrm{Mgal} / \mathrm{d}$ in 1980 to $85.54 \mathrm{Mgal} / \mathrm{d}$ in 1990 and decreased to $68.15 \mathrm{Mgal} / \mathrm{d}$ in 2000 (Payne and others, 2005).

\section{Hydrogeologic Setting}

Chatham County (fig. 1) is underlain by Coastal Plain strata consisting of consolidated to unconsolidated layers of sand and clay and semiconsolidated to very dense layers of limestone and dolomite (Miller, 1986; Clarke and others, 1990; Williams and Gill, 2010). These sediments constitute three major aquifer systems, which are, in descending order, the surficial aquifer system, the Brunswick aquifer system, and the Floridan aquifer system. The Brunswick aquifer system near Pooler contains material of low permeability and no discernible water-bearing units (fig. 2).

In the coastal area, the surficial aquifer system consists of Miocene and younger interlayered sand, clay, and thin limestone beds (Clarke, 2003). At Pooler, the surficial aquifer system consists of fine sands at depths of less than $100 \mathrm{ft}$ and largely is unconfined. Elsewhere in coastal Georgia, the surficial aquifer system includes a water-table zone and two confined water-bearing zones; however, the areal extent of the confined water-bearing zones is unknown (Clarke, 2003). The surficial aquifer system is separated from the underlying Brunswick aquifer system by a confining unit consisting of silty clay and dense, phosphatic Miocene limestone.

The Oligocene to Miocene Brunswick aquifer system consists of two water-bearing zones - the upper Brunswick aquifer and the lower Brunswick aquifer (Clarke, 2003). The upper Brunswick aquifer consists of poorly sorted, fine to coarse, slightly phosphatic and dolomitic, quartz sand and dense, phosphatic limestone (Clarke and others, 1990). The lower Brunswick aquifer consists of poorly sorted, fine to coarse, phosphatic and dolomitic Oligocene and Miocene sand (Clarke and others, 1990). At Pooler, the Brunswick aquifer system consists of clayey fine sand and silt that has much lower permeability than in the Brunswick, Ga., area and can largely be considered a confining unit. For this study, the upper and lower Brunswick aquifers are considered a single unit, and the combined thickness and composite hydraulic properties are used for model simulations.

The principal source of water for all uses (excluding thermoelectric) in the coastal area of Georgia is the Floridan aquifer system, which is the subject of this report. The following description of the Floridan aquifer system at Pooler is from Gonthier (2012):

"Based on flowmeter surveys, driller cuttings, and geophysical logs at well 35Q069, the Floridan aquifer system at Pooler extends in depth from 333 to 1,040 ft. The Upper 


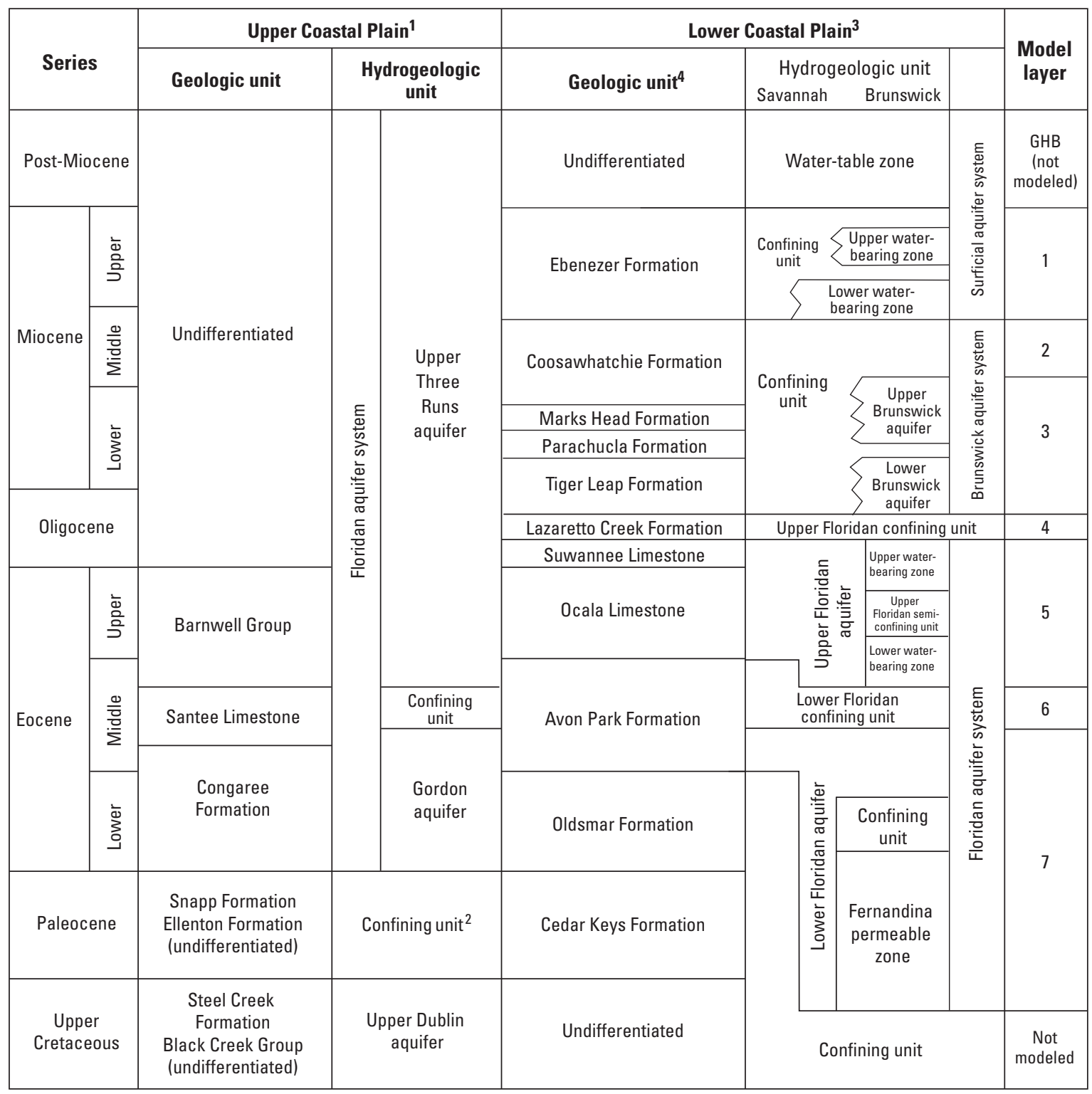

${ }^{1}$ Modified from Falls and others, 1997.

${ }^{2}$ In local areas includes Millers Pond aquifer.

${ }^{3}$ Modified from Randolph and others, 1991; Clarke and Krause, 2000.

${ }^{4}$ Modified from Randolph and others, 1991; Weems and Edwards, 2001.

Figure 2. Generalized correlation of geologic and hydrogeologic units and model layers in the Coastal Plain of Georgia (modified from Payne and others, 2005). [GHB, general head boundary]

Floridan confining unit extends in depth from 301 to $333 \mathrm{ft}$; the UFA extends from 333 to $515 \mathrm{ft}$ depth; the Lower Floridan confining unit (LFCU) extends from 515 to $702 \mathrm{ft}$ depth; and the LFA extends from 702 to $1,040 \mathrm{ft}$."

The UFA mostly consists of Oligocene and upper Eocene carbonate units with a thickness of $182 \mathrm{ft}$ at Pooler. Gonthier (2012) reported that estimated transmissivity of the UFA, based on results from 24-hr and 72-hr aquifer tests, ranged from 30,000 to 46,000 feet squared per day $\left(\mathrm{ft}^{2} / \mathrm{d}\right)$; the higher value is believed to be more representative of the actual value.

The UFA is underlain by the LFCU, which consists of chalky and glauconitic limestone in the uppermost part of the middle Eocene Avon Park Formation with a thickness of $187 \mathrm{ft}$ at Pooler (Gonthier, 2012). Thickness and hydraulic conductivity of the confining unit control the rate of interaquifer leakage between the UFA and LFA. A flowmeter survey indicated that the LFCU contributed little to the overall flow in a test hole open to the entire Floridan aquifer system, and a single water-bearing zone is present between depths of 550 and $620 \mathrm{ft}$, yielding 21.3 gallons per minute (gal $/ \mathrm{min}$ ). The $\mathrm{K}_{\mathrm{v}}$ of three core samples ranged from 0.57 to 1.57 feet per day $(\mathrm{ft} / \mathrm{d})$. Slug tests at three separate intervals indicate the horizontal hydraulic conductivity $\left(\mathrm{K}_{\mathrm{h}}\right)$ of the LFCU ranged from less than 1 to $10 \mathrm{ft} / \mathrm{d}$ (Gonthier, 2012). 
The LFA at well 35Q069 consists of chalky and glauconitic limestone in the upper part of the middle Eocene Avon Park Formation, which is similar in lithology to overlying units. The top of the LFA is located at a depth of $702 \mathrm{ft}$ and extends to a depth of $1,040 \mathrm{ft}$ (Gonthier, 2012). Results of flowmeter testing identified five water-bearing depth intervals within the LFA: 705-745, 745-925, 925-984, 984-1,015, and 1,015-1,040 ft; the interval 745-925 ft contributed 84 percent of the total flow of $780 \mathrm{gal} / \mathrm{min}$ (Gonthier, 2012). No flow was detected below a depth of $1,040 \mathrm{ft}$ where the lower confining unit is present. Gonthier (2012) reported that estimated transmissivity of the LFA, based on simulated results from a 72 -hr aquifer test, was $4,000 \mathrm{ft}^{2} / \mathrm{d}$.

\section{Groundwater Flow}

Groundwater flow in the Floridan aquifer system is determined by the rate and distribution of recharge to and discharge from the system, the extent and effectiveness of confinement, and the ability of aquifers to transmit and store water (Krause and Randolph, 1989). The conceptualized predevelopment (no pumping) and modern-day (2000) groundwater-flow systems in coastal Georgia (fig. 3) receive water from precipitation and downward leakage through shallow geologic units that recharge the aquifers in the northern part of the coastal area where the units are exposed at or near land surface. Groundwater then flows mostly southeastward toward the coast where it discharges into overlying units and surface-water bodies. Prior to development, the flow system was considered to be in dynamic equilibrium, where recharge balances discharge, and potentiometric surfaces were considered nearly static from year to year. Generally predevelopment potentiometric surfaces were higher than current groundwater levels, and test wells tapping the Floridan aquifer system flowed at the surface along the coast (fig. $3 A$ ).
The modern-day (2000) flow system reflects changes that have occurred as a result of groundwater development (withdrawals; fig. 3B). Groundwater withdrawals have lowered water levels, induced additional recharge from vertical leakage and regional flow, reduced natural discharge, and degraded the quality of water in places along the coast. Groundwater pumping has caused an extensive cone of depression to develop in the potentiometric surface of the UFA in the Savannah area (fig. 1). This cone of depression has affected groundwater flow near Pooler, as evidenced by the shape of potentiometric contours, indicating groundwater flow is toward the center of the cone of depression.

Saltwater contamination restricts the development of groundwater supply in coastal Georgia and adjacent parts of South Carolina and Florida (Krause and Clarke, 2001). Pumping from the UFA has resulted in substantial groundwater-level decline; subsequent saltwater intrusion into the UFA at Brunswick, Ga., from underlying strata containing highly saline water; and encroachment of seawater into the UFA at the northern end of Hilton Head Island, S.C. Saltwater contamination at these locations has constrained further development of the UFA in the coastal area and has created competing demands for the limited supply of freshwater.

\section{Well Identification}

In this report, wells are identified by a USGS numbering system based on the index of USGS topographic maps (such as 35Q069). In Georgia, each 7-1/2-minute topographic quadrangle map has been given a number and letter designation beginning at the southwestern corner of the State. Numbers increase eastward through 39, and letters increase alphabetically northward through " $Z$ " and then become double-letter designations "AA" through "PP." The letters "I" and "O" are not used. Wells inventoried in each quadrangle are numbered sequentially beginning with "1." For example, well 35Q069 is the 69th well inventoried in the Meldrim SE quadrangle (map 35Q). 


\section{A. Predevelopment}

NORTHWEST

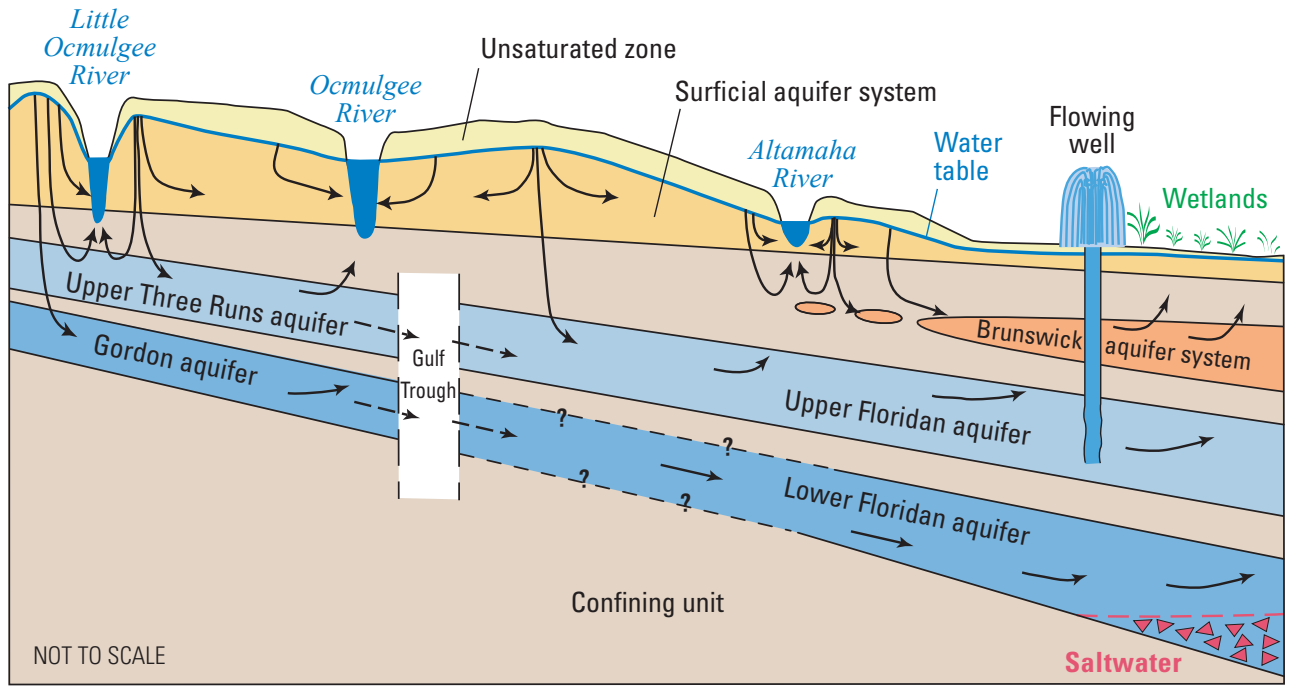

\section{B. Modern day}

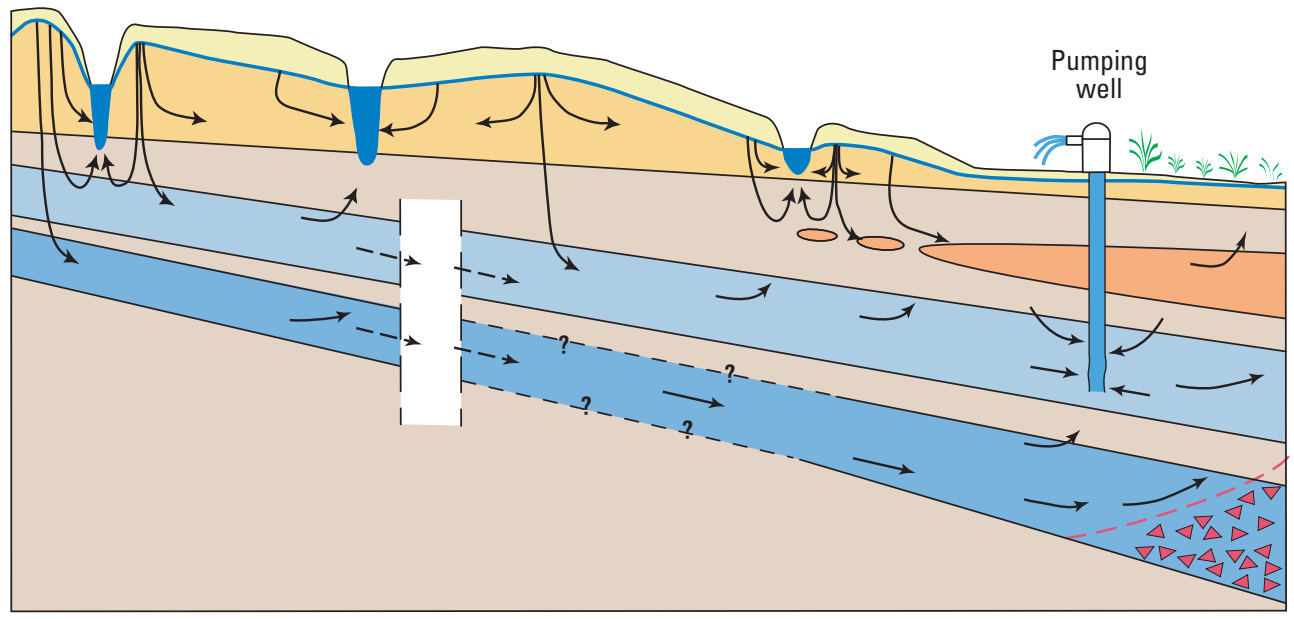

Figure 3. Schematic diagram showing conceptual model of $(A)$ predevelopment and $(B)$ modern-day (2000) flow system. Arrows indicate general direction of groundwater flow (modified from Priest, 2004; Payne and others, 2005).

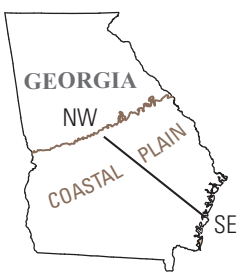




\section{Simulated Effects of Lower Floridan Aquifer Pumping on the Upper Floridan Aquifer}

Groundwater simulation provides a quantitative estimate of the long-term (steady-state) leakage response of the UFA to pumping from the LFA and estimates the equivalent amount of UFA pumpage that would produce similar drawdown in the UFA to that caused by pumping-induced leakage to the LFA. Aquifer testing at Pooler, Ga., provided (1) the basis to monitor and record drawdown response in nearby UFA wells to pumping in the LFA and (2) a data set of hydrologic conditions that were used to estimate hydraulic properties and assess simulation accuracy. Drawdown response in the UFA to pumping the LFA was evaluated by simulation of a variety of hypothetical pumping scenarios in the UFA and LFA.

\section{Observed Water-Level Response}

LFA well 35Q069 was pumped at rates ranging from 780.3 to $787.6 \mathrm{gal} / \mathrm{min}$ for a 72 -hr period beginning on April 16, 2012. In this report, an average rate of $780 \mathrm{gal} / \mathrm{min}$ was used to simulate aquifer-test conditions. Raw, unfiltered water-level data (fig. 4) indicate distinct water-level declines in UFA well 35Q070 and in pumped LFA well 35Q069 (Gonthier, 2012). During the 72-hr test, drawdown of $52.05 \mathrm{ft}$ was observed in pumped well 35Q069, and $0.9 \mathrm{ft}$ of drawdown was observed in UFA well 35Q070 (located $85 \mathrm{ft}$ from the pumped well). Filtering of water-level data using the spreadsheet procedure of Halford (2006) isolated the drawdown response from unrelated natural and anthropogenic influences, such as tidal, barometric, and regional pumping influences. The result of filtering produced synthesized water levels that presumably contain only drawdown resulting from the pumped well 35Q069 (fig. 4). The synthesized water

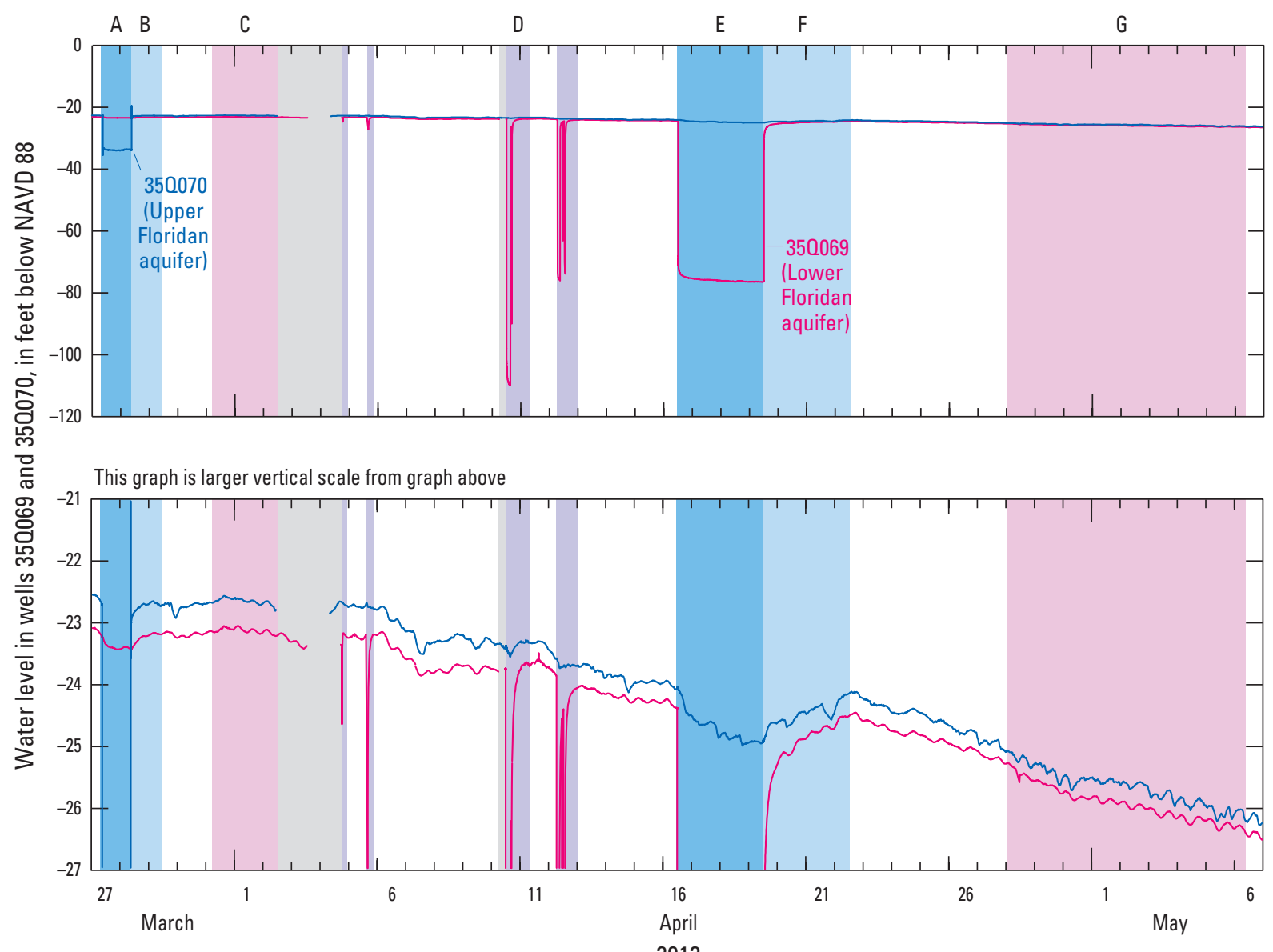

Figure 4. Water levels in wells 350069 and 350070 before, during, and after the 24-hour Upper Floridan and 72-hour Lower Floridan aquifer tests at Pooler, Georgia, March 27-May 6, 2012. A, Pumping phase of Upper Floridan 24-hour aquifer test. $B$, Recovery phase of Upper Floridan 24-hour aquifer test. $C$, Early fitting period. $D$, Failed Lower Floridan aquifer test. $E$, Pumping phase of Lower Floridan 72-hour aquifer test. $F$, Recovery phase of Lower Floridan 72-hour aquifer test. $G$, Late fitting period. The

\section{EXPLANATION}

Pumping phase of aquifer test Recovery phase of aquifer test Fitting period

Data gap in at least one well Other pumping event fitting period is used to describe the match (or fit) of synthetic water levels to those that were measured. (From Gonthier, 2012.) 
levels indicated drawdown resulting from pumping LFA well 35Q069 was $0.9 \mathrm{ft}$ in UFA well 35Q070 and $52 \mathrm{ft}$ in LFA well 35Q069 (Gonthier, 2012).

Graphs showing drawdown indicate that drawdown in the LFA was nearly stable, whereas in the UFA drawdown continued to decline at the end of the 72-hr test period (fig. 4). Because test pumping at LFA well 35Q069 was discontinued before drawdown had stabilized in the UFA, model simulation was used to determine long-term, steady-state effects on the Floridan aquifer system beyond the aquifer-test period. Simulations by Payne and others (2005) in coastal Georgia indicate that it could take 5 years or more to reach a steady-state condition in the Chatham County area. Because a 5-year-long aquifer test is impractical, model simulation provided a means to estimate the long-term steady-state condition.

\section{Model Simulation}

Model simulation was used to simulate factors described in the GaEPD interim strategy for permitting LFA groundwater withdrawals in the 24-county coastal Georgia area (Nolton Johnston, Georgia Environmental Protection Division, written commun., January 28, 2003), namely, to (1) quantify aquifer leakage from the UFA to LFA resulting from pumping the new LFA well and (2) calculate "the equivalent Upper Floridan pumping that induces the identical maximum drawdown in the Upper Floridan that would be expected as a result of pumping the Lower Floridan."

Model simulations required modification of the regional groundwater-flow model of Payne and others (2005) to a finer spatial resolution and to incorporate hydrogeologic information obtained from field investigations at Pooler (described earlier) and from nearby existing wells (described in the appendix). The effects of pumping LFA well 35Q069 on groundwater levels and interaquifer leakage in the Floridan aquifer system were evaluated with simulations using the revised model, which represented average pumping rates for 2010 in Pooler wells, and pumping rates for 2000 elsewhere, as a base case for the evaluations.

Steady-state simulations of the following groundwatermodel scenarios were used to quantify the long-term response of the Floridan aquifer system to changes in groundwater pumpage in both the UFA and LFA (table 1).

- Scenario A-LFA well 35Q069 was pumped at a rate of $780 \mathrm{gal} / \mathrm{min}$ (approximately same rate used during the 72-hr aquifer test).

- Scenario B-LFA well 35Q069 was pumped at a rate of $1,042 \mathrm{gal} / \mathrm{min}$.
- Scenario C-LFA well 35Q069 was pumped at a rate of $390 \mathrm{gal} / \mathrm{min}$ or one-half the pumping rate simulated in scenario A.

- Scenario D-UFA well 35Q070 was pumped at a rate that would produce the same amount of UFA drawdown that was simulated from vertical leakage induced by pumping LFA well 35Q069 at a rate of $780 \mathrm{gal} / \mathrm{min}$ (simulated in scenario A). Note that several model runs were performed on a trial-and-error basis to achieve a drawdown match.

- Scenario E-UFA well 35Q070 was pumped at a rate that would produce the same amount of drawdown in the UFA as that resulting from pumping LFA well $35 \mathrm{Q} 069$ at a rate of $1,042 \mathrm{gal} / \mathrm{min}$ (simulated in scenario B). Note that several model runs were performed on a trial-and-error basis to achieve a drawdown match.

- Scenario F-UFA well 35Q070 was pumped at a rate that would produce the same amount of drawdown in the UFA as that resulting from pumping LFA well 35Q069 at a rate of $390 \mathrm{gal} / \mathrm{min}$ (simulated in scenario C). Note that several model runs were performed on a trial-and-error basis to achieve a drawdown match.

- Scenario G-LFA well 35Q069 was pumped at $780 \mathrm{gal} / \mathrm{min}$, and total pumpage from existing UFA wells at Pooler was reduced by $255 \mathrm{gal} / \mathrm{min}$. The reduction in UFA pumpage represents the amount of UFA pumping that would produce maximum drawdown in the UFA equivalent to that induced by pumping the LFA at $780 \mathrm{gal} / \mathrm{min}$ (results of scenario D).

- Scenario H-LFA well 35Q069 was pumped at a rate of 1,042 gal/min, and total pumpage from existing UFA wells at Pooler was reduced by $340 \mathrm{gal} / \mathrm{min}$. The UFA pumpage reduction represents the amount of UFA pumping that would produce drawdown in the UFA equivalent to that induced by pumping the LFA at 1,042 $\mathrm{gal} / \mathrm{min}$ (results of scenario E).

- Scenario I-LFA well 35Q069 was pumped at a rate of $390 \mathrm{gal} / \mathrm{min}$, and total pumpage from existing UFA wells at Pooler was reduced by $128 \mathrm{gal} / \mathrm{min}$. The UFA pumpage reduction represents the amount of UFA pumping that would produce drawdown in the UFA equivalent to that induced by pumping the LFA at $390 \mathrm{gal} / \mathrm{min}$ (results of scenario F). 


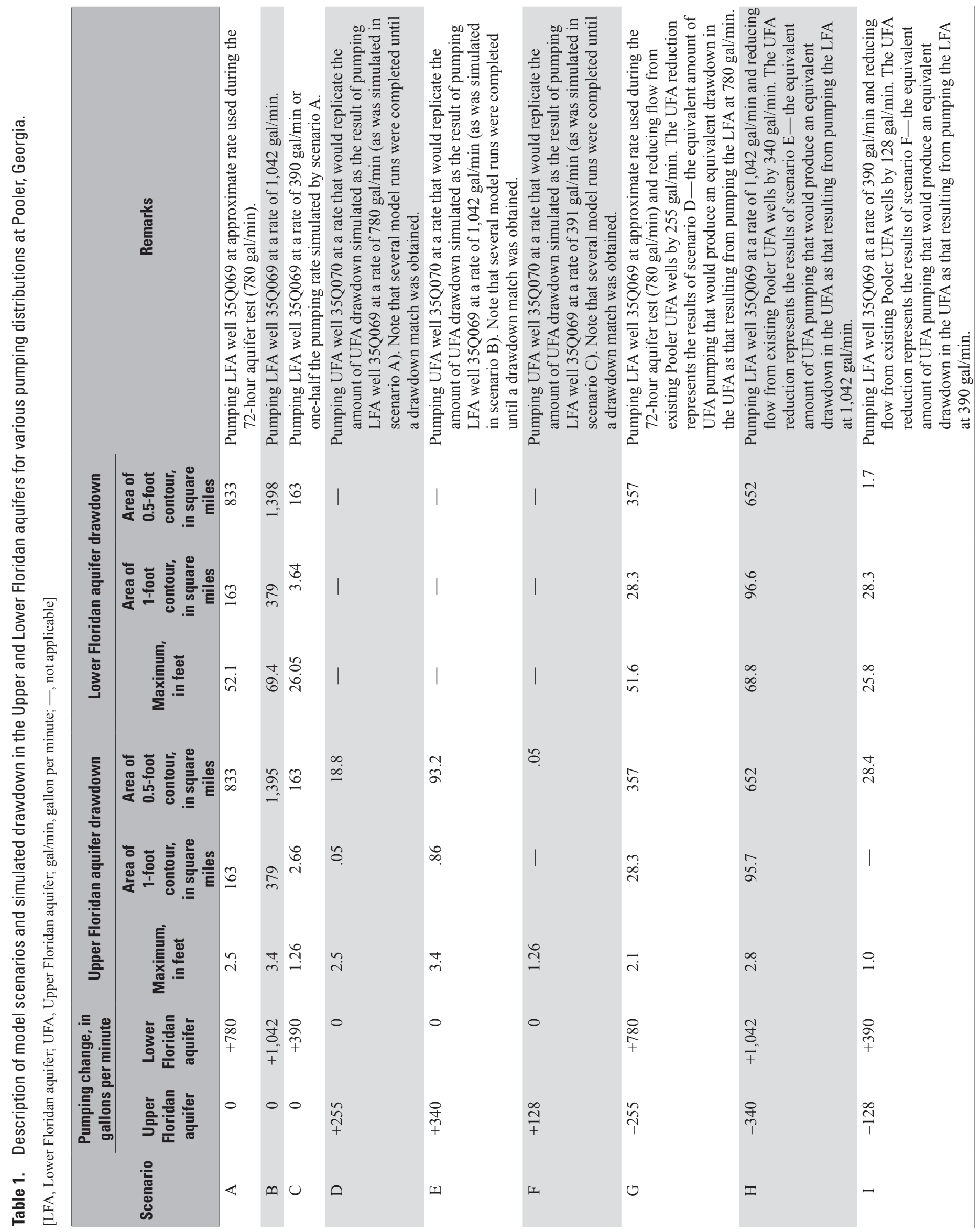




\section{Interaquifer Leakage and Drawdown Response}

For scenario A, simulated pumping of LFA well 35Q069 at a rate of $780 \mathrm{gal} / \mathrm{min}$ resulted in a maximum steady-state drawdown of $52.1 \mathrm{ft}$ (table 1, fig. 5), which is nearly identical to the 52-ft maximum drawdown observed during the test (fig. 4). Because changes in water levels over time were approaching zero by the end of the 72-hr test, the steady-state simulation seems to be a reasonable estimate of field conditions in the LFA. Simulated steady-state drawdown in the LFA for scenario A exceeded $1 \mathrm{ft}$ over an area of $163 \mathrm{mi}^{2}$ (fig. 5 , table 1).

Simulated pumping of LFA well 35Q069 at $780 \mathrm{gal} / \mathrm{min}$ (scenario A) caused leakage through the LFCU, which resulted in drawdown in the overlying UFA (fig. 6). Because water levels in the UFA had not stabilized at the end of the 72-hr test, observed drawdown in well 35Q070 was considered a lower limit for steady-state model calibration. Comparison of simulated drawdown to drawdown determined from filtered water-level data at the end of the 72-hr aquifer test in LFA well 35Q069 indicates that the simulated steady-state UFA drawdown of $2.52 \mathrm{ft}$ exceeded the observed value of $0.9 \mathrm{ft}$ in well $35 \mathrm{Q} 070$ by $1.62 \mathrm{ft}$. This difference is expected because the model simulated the long-term steady-state response to pumping conditions, no further changes in drawdown over time, whereas the field data represent a short-term, transient condition in which drawdown in the UFA still was accumulating at the end of the 72-hr test. Model results for scenario A indicate that drawdown in the UFA exceeded $1 \mathrm{ft}$ over a 163- $\mathrm{mi}^{2}$ area (table 1 ).

To assess the amount of leakage resulting from pumping in the LFA, the steady-state water budgets before and after pumping at well 35Q069 were compared (table 2). Because of independent rounding, water budget values listed in table 2 may not add to totals; however, comparison of values provides some insight into the relative contribution of flow to LFA well 35Q069. Pumping 1.12 Mgal/d (780 gal $/ \mathrm{min}$ ) at well 35Q069 resulted in small changes to the regional water budget and the following redistribution of flow among model layers:
- Layer 1-A 0.38 Mgal/d increase in inflow (recharge) from, and a $0.097 \mathrm{Mgal} / \mathrm{d}$ decrease in discharge to, the general head boundary for a net flow of $+0.48 \mathrm{Mgal} / \mathrm{d}$;

- Layer 2-A $0.026 \mathrm{Mgal} / \mathrm{d}$ increase in inflow (recharge) from, and a $0.004 \mathrm{Mgal} / \mathrm{d}$ decrease in discharge to, the general head boundary for a net flow of $+0.03 \mathrm{Mgal} / \mathrm{d}$;

- Layer 5-A $0.007 \mathrm{Mgal} / \mathrm{d}$ increase in inflow (recharge) from, and a $0.007 \mathrm{Mgal} / \mathrm{d}$ decrease in discharge to, the general head boundary and a $0.52 \mathrm{Mgal} / \mathrm{d}$ increase in flow from, and $0.089 \mathrm{Mgal} / \mathrm{d}$ decrease in discharge to, lateral specified-head boundaries for a net flow of $+0.623 \mathrm{Mgal} / \mathrm{d}$; and

- Layer 7-A $0.014 \mathrm{Mgal} / \mathrm{d}$ increase in flow from, and a $0.01 \mathrm{Mgal} / \mathrm{d}$ decrease in discharge to, lateral specifiedhead boundaries for a net flow of $+0.024 \mathrm{Mgal} / \mathrm{d}$.

For scenario A, of the $1.12 \mathrm{Mgal} / \mathrm{d}$ pumping rate in well 35Q069, 98 percent of the flow was derived from increased leakage from overlying layers, and 2 percent was from the lateral specified-head boundary for the LFA (layer 7). Most of the flow from overlying layers was from lateral specified-head boundaries in the UFA (layer 5), which had a net contribution of $0.61 \mathrm{Mgal} / \mathrm{d}$. The remainder of flow from overlying layers was contributed from the general head boundary in layers 1,2 , and 5 .

Simulation results for scenario A were further examined using USGS ZONEBUDGET (Harbaugh, 1990) to obtain the percentage of total interaquifer leakage from the UFA to the LFA that contributed to the pumped LFA well from within designated zones centered at the pumped LFA well (fig. 7). Three concentric zones centered at well 35Q069 were designated -0 to $0.5 \mathrm{mi}, 0.5$ to $1 \mathrm{mi}$, and greater than $1 \mathrm{mi}$. Eighty-one percent of the interaquifer leakage from the UFA that contributed water to well 35Q069 came from within $1 \mathrm{mi}$ of the pumped well; 58 percent came from within $0.5 \mathrm{mi}$ of the pumped well. Progressively steeper vertical hydraulic gradients between the pumped LFA well and overlying UFA result in greater vertical leakage near the pumped well. 


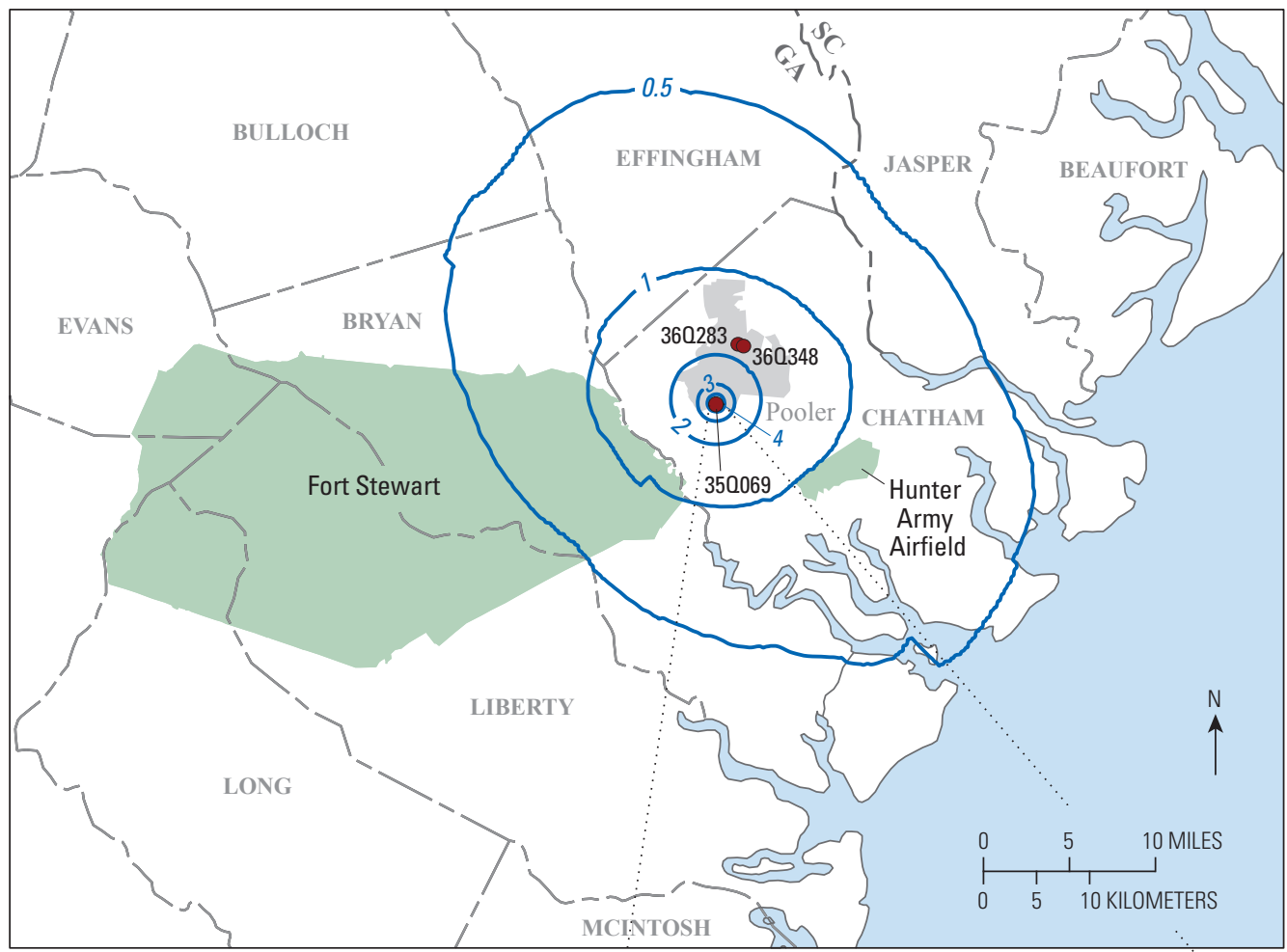

Base map from U.S. Geological Survey 1:2,000,000-scale digital data

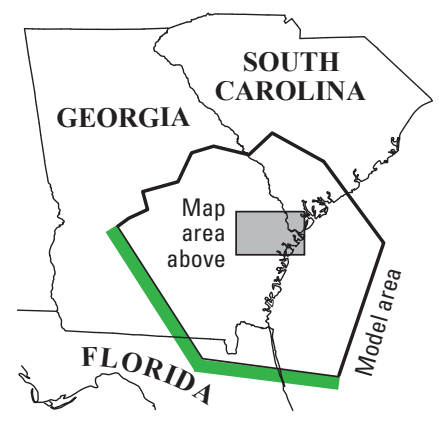

\section{EXPLANATION}
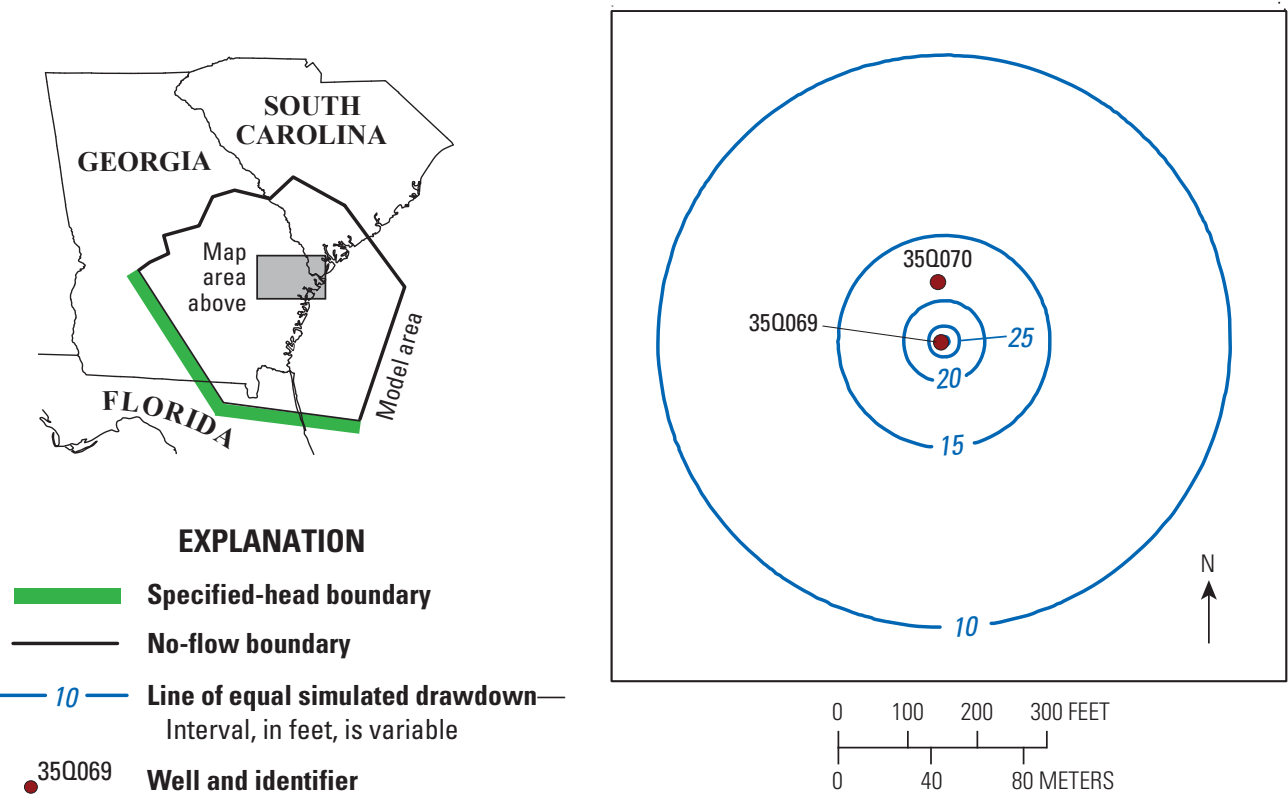

Figure 5. Simulated steady-state drawdown in the Lower Floridan aquifer for scenario A-pumping Lower Floridan aquifer well 350069 at 780 gallons per minute, Pooler and vicinity, Georgia. Maximum drawdown in well 350069 is 52.1 feet. 


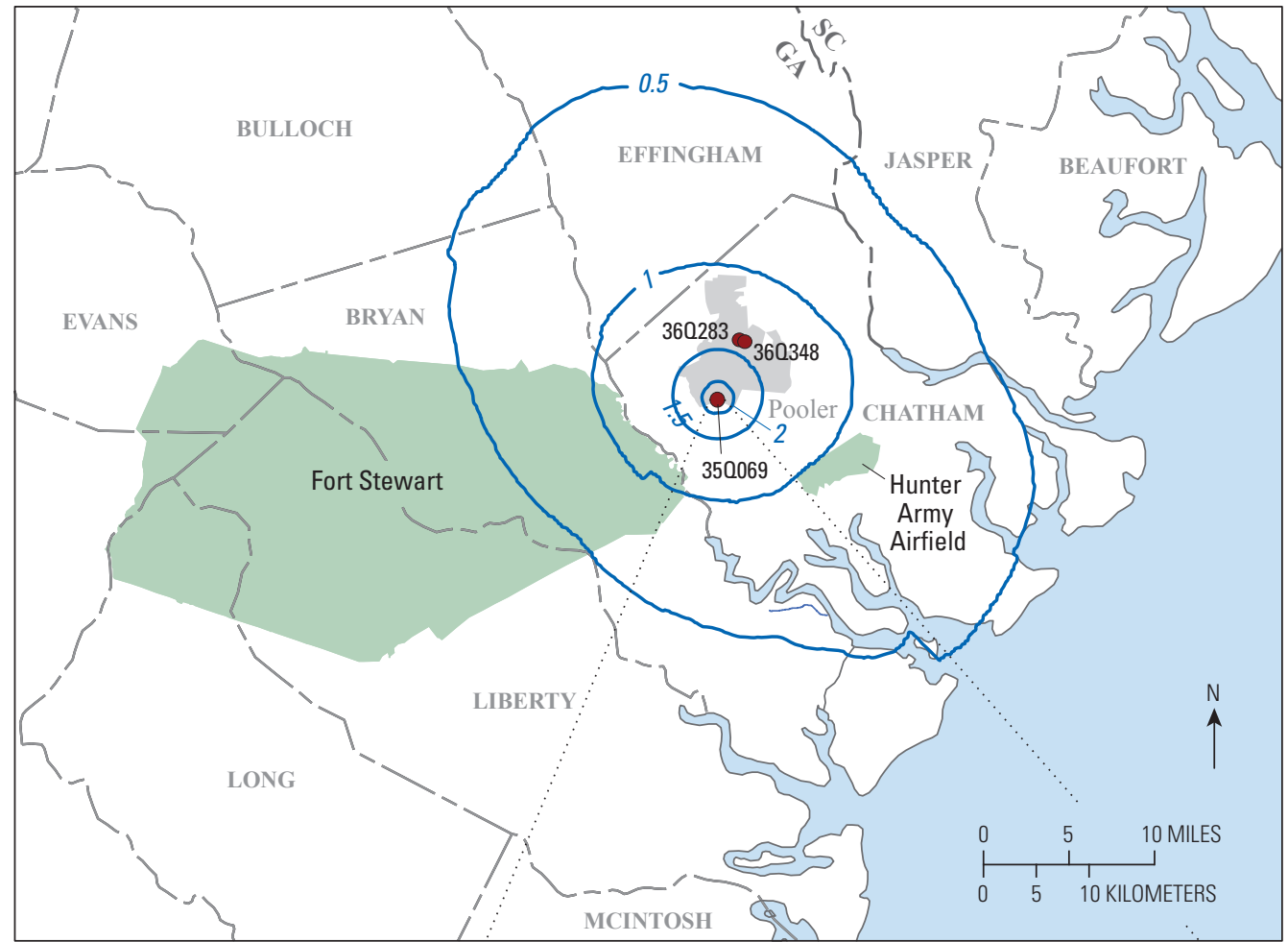

Base map from U.S. Geological Survey 1:2,000,000-scale digital data

- 10 - Line of equal simulated
drawdown-Interval, in feet, is variable

350069 Well and identifier

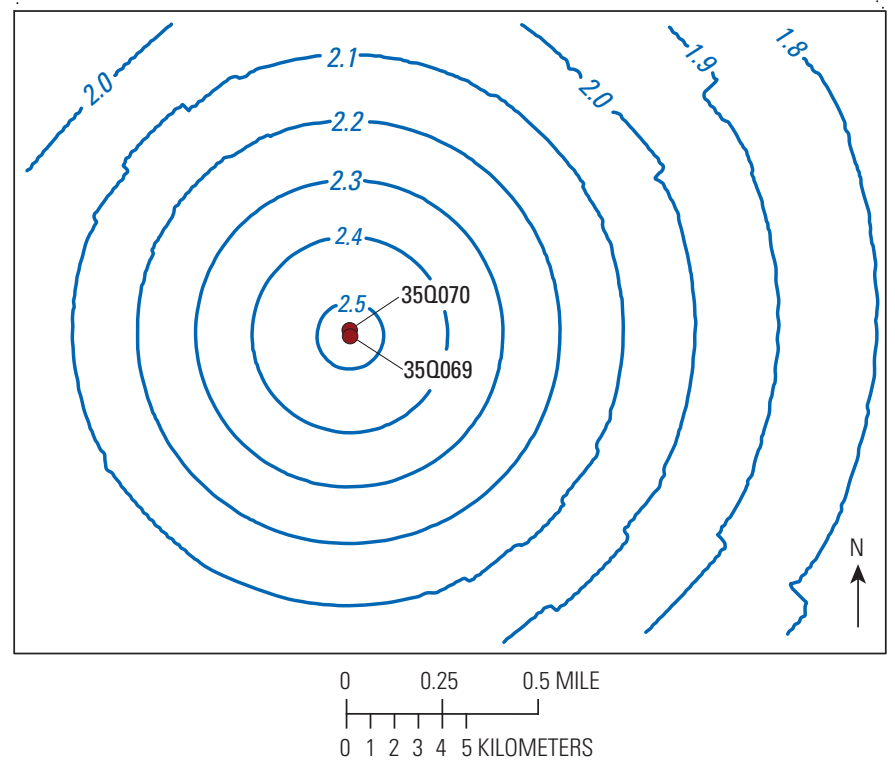

Figure 6. Simulated steady-state drawdown in the Upper Floridan aquifer for scenario A—pumping Lower Floridan aquifer well 350069 at 780 gallons per minute, Pooler and vicinity, Georgia. Maximum drawdown in well 350069 is 2.5 feet. 


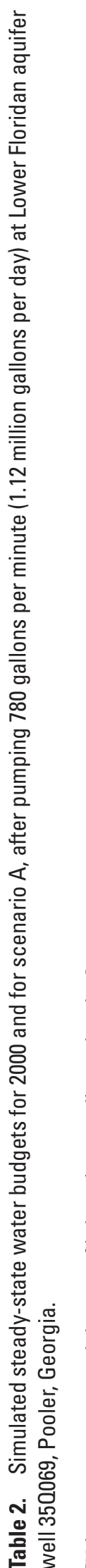

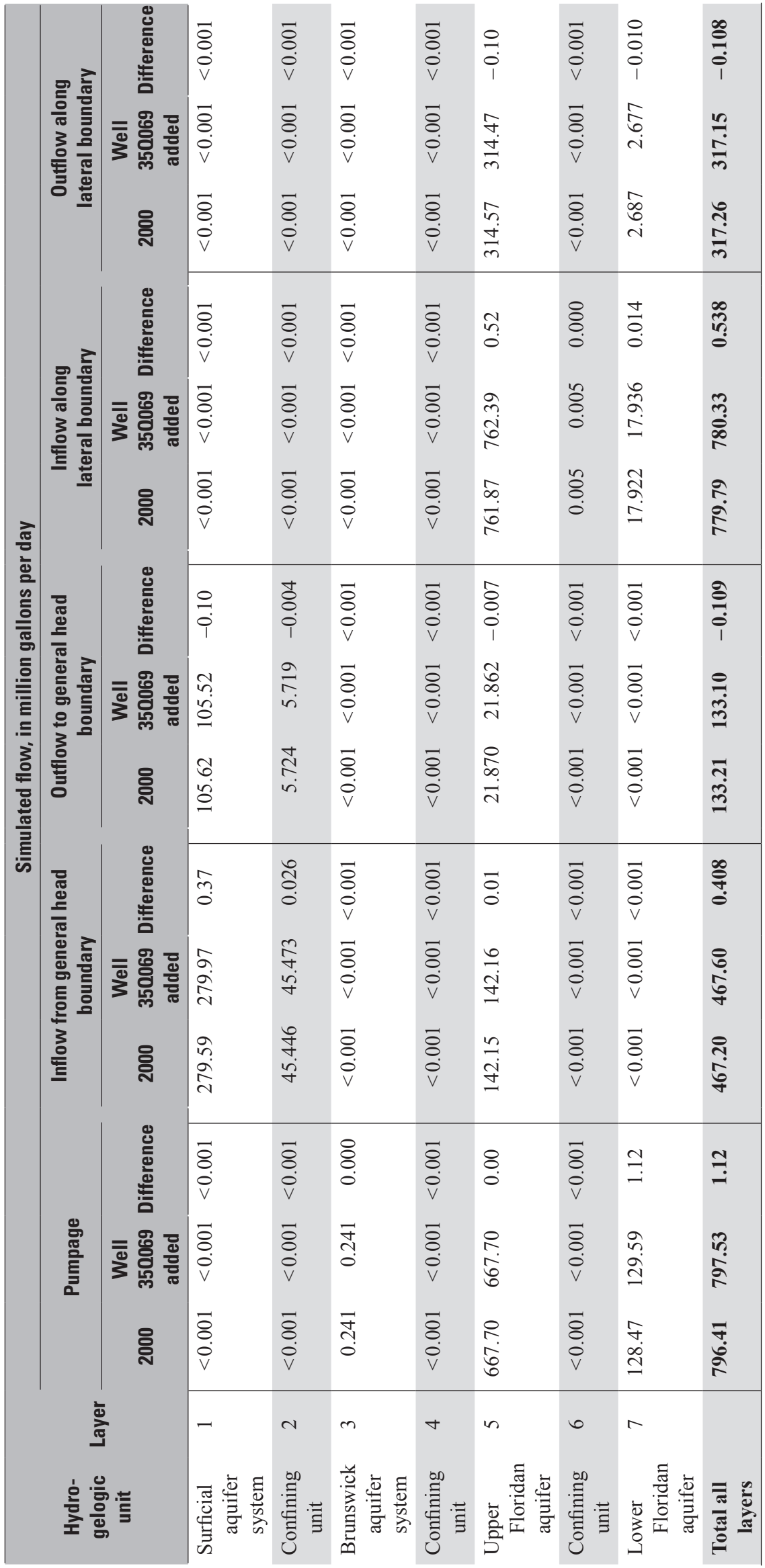




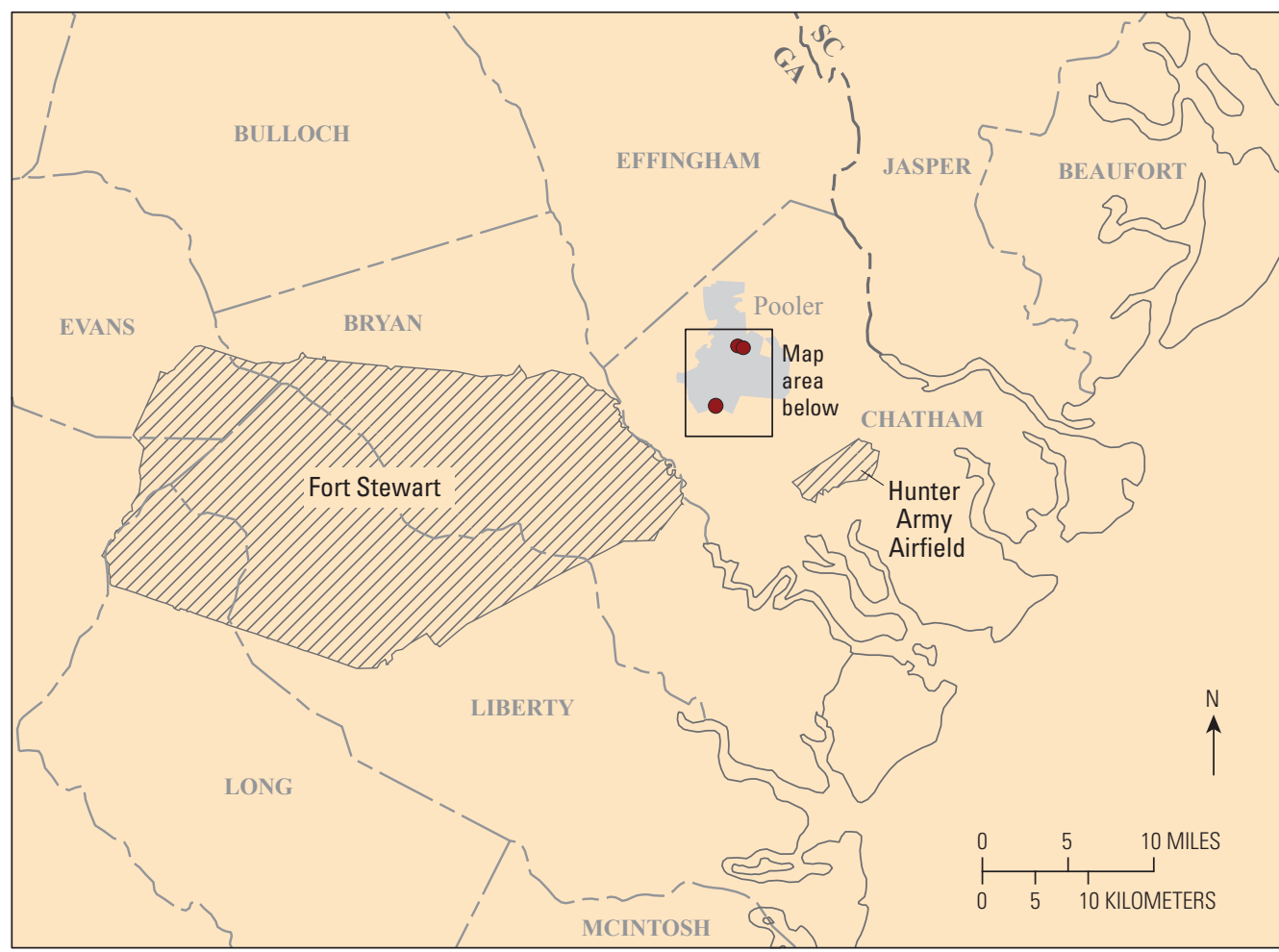

Base map from U.S. Geological Survey 1:2,000,000-scale digital data

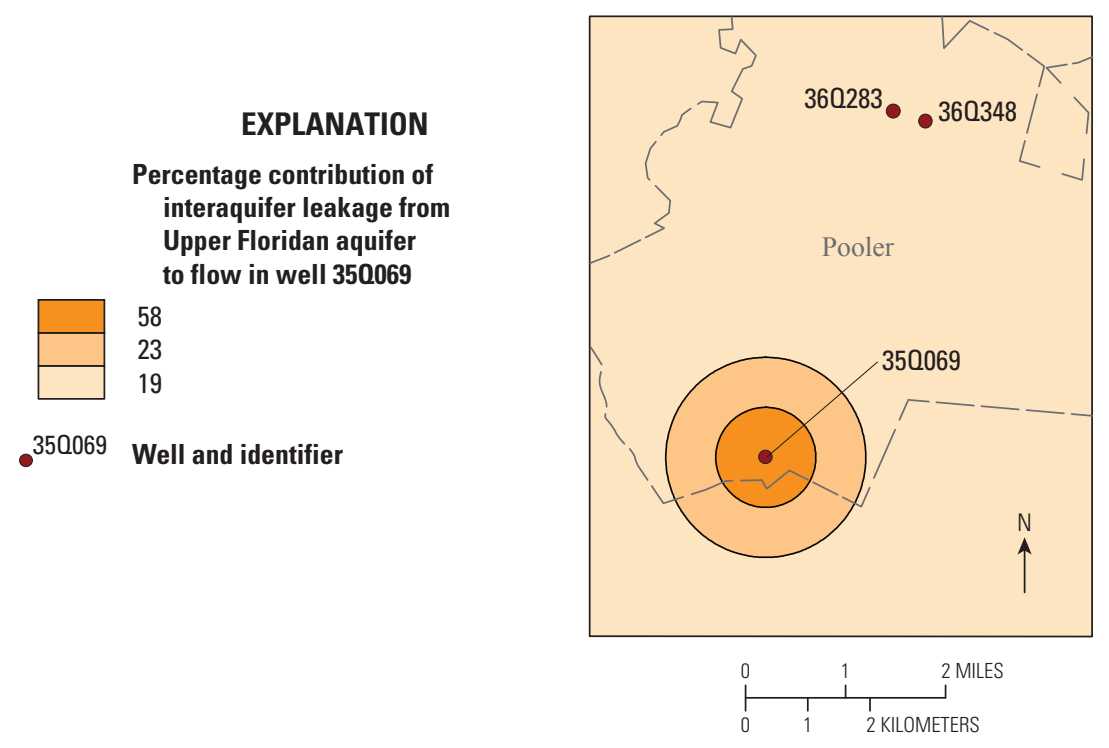

Figure 7. Distribution of interaquifer leakage from the Upper Floridan aquifer for scenario A-lower Floridan aquifer well 350069 pumping at a rate of 780 gallons per minute, Pooler and vicinity, Georgia. 
For scenario B, pumping at LFA well 35Q069 was increased to $1,042 \mathrm{gal} / \mathrm{min}$ or $1.5 \mathrm{Mgal} / \mathrm{d}$ (table 1 ). Model results for scenario $\mathrm{B}$ indicate that drawdown in the LFA reached a maximum of $69.4 \mathrm{ft}$ and exceeded $1 \mathrm{ft}$ over a $379-\mathrm{mi}^{2}$ area (table 1; fig. 8). In the UFA, water levels reached a maximum drawdown of $3.4 \mathrm{ft}$ in response to the pumping of well 35Q069 and exceeded $1 \mathrm{ft}$ over a 379- $\mathrm{mi}^{2}$ area.

Comparison of the steady-state water budgets before and after pumping at well 35Q069 for scenario B (table 3) showed a pattern similar to that simulated for scenario A (table 2), including

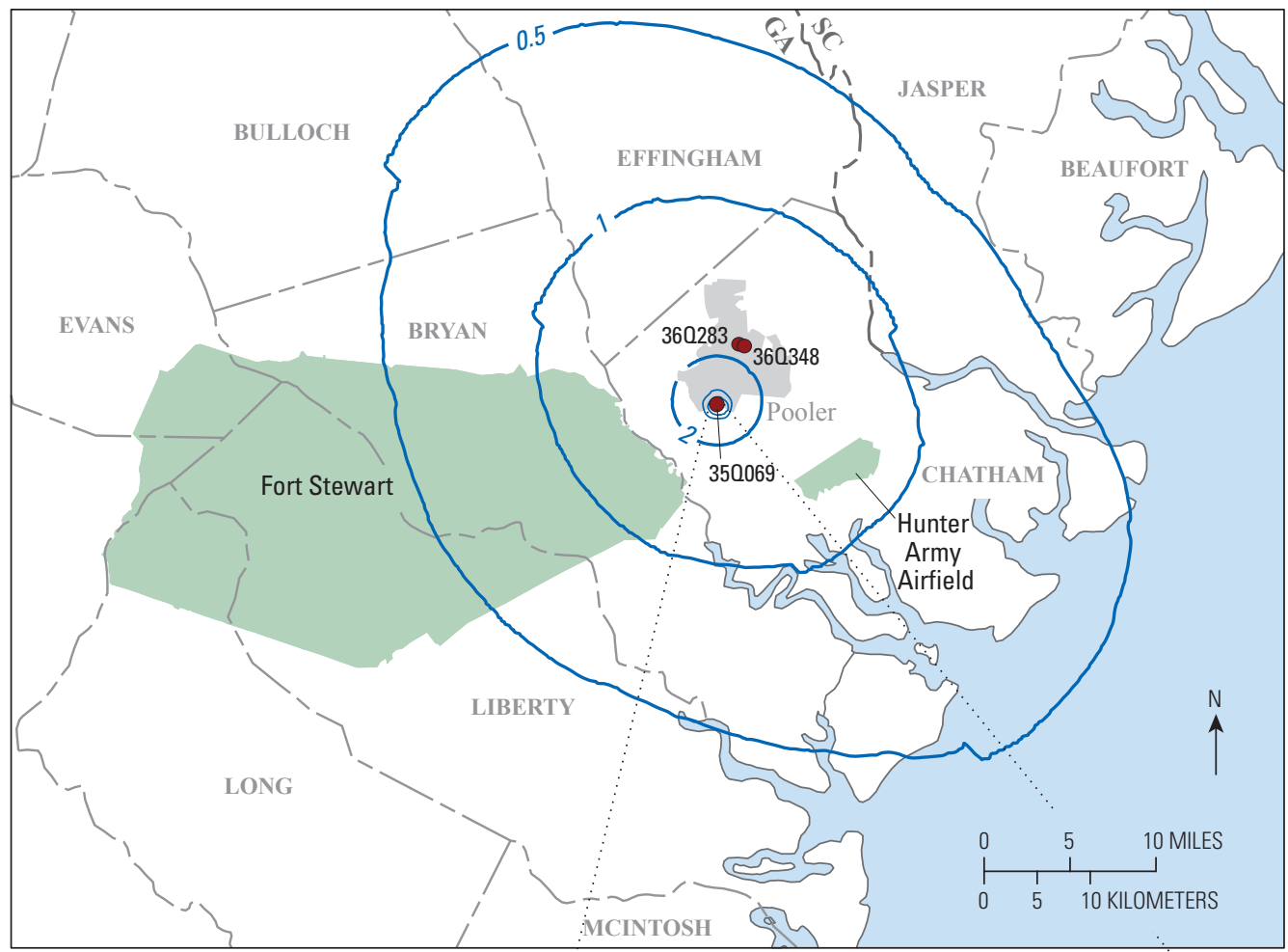

Base map from U.S. Geological Survey 1:2,000,000-scale digital data

EXPLANATION

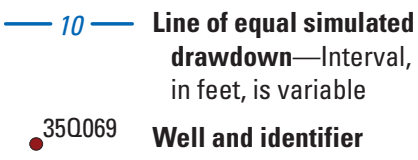

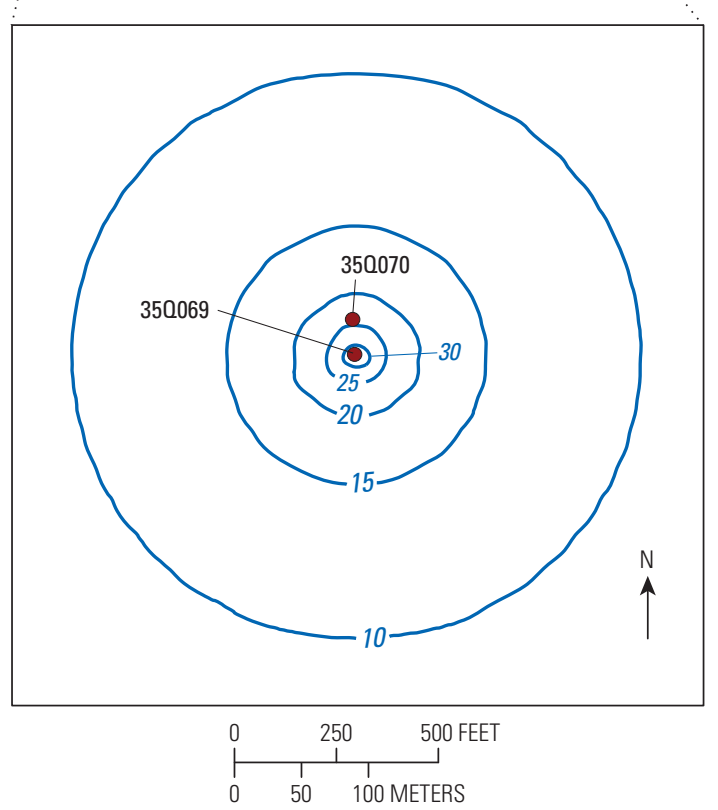

Figure 8A. Simulated steady-state drawdown in the Lower Floridan aquifer for scenario B-pumping Lower Floridan aquifer well 350069 at 1,042 gallons per minute, Pooler and vicinity, Georgia. Maximum drawdown in well 350069 is 69.4 feet. 
- Layer 1-A $0.51 \mathrm{Mgal} / \mathrm{d}$ increase in inflow (recharge) from the general head boundary and a $0.13 \mathrm{Mgal} / \mathrm{d}$ decrease in discharge to the general head boundary for a net change of $+0.64 \mathrm{Mgal} / \mathrm{d}$;

- Layer 2-A $0.035 \mathrm{Mgal} / \mathrm{d}$ increase in inflow (recharge) from, and $0.006 \mathrm{Mgal} / \mathrm{d}$ decrease in flow to, the general head boundary, for a net flow of $+0.041 \mathrm{Mgal} / \mathrm{d}$;

- Layer 5-A $0.015 \mathrm{Mgal} / \mathrm{d}$ increase in inflow (recharge) from, and $0.01 \mathrm{Mgal} / \mathrm{d}$ decrease in discharge to, the general head boundary and a $0.67 \mathrm{Mgal} / \mathrm{d}$ increase in flow from, and a $0.12 \mathrm{Mgal} / \mathrm{d}$ decrease in discharge to, lateral specified-head boundaries, for a net change of $+0.82 \mathrm{Mgal} / \mathrm{d}$; and

- Layer 7-a $0.019 \mathrm{Mgal} / \mathrm{d}$ increase in flow from lateral specified-head boundaries and a $0.014 \mathrm{Mgal} / \mathrm{d}$ decrease in discharge to lateral specified-head boundaries for a net change of $+0.033 \mathrm{Mgal} / \mathrm{d}$.

As was the case for scenario A, 2 percent of the flow to well 35Q069 was provided by lateral boundaries in layer 7, and 98 percent was provided by flow from overlying layers.

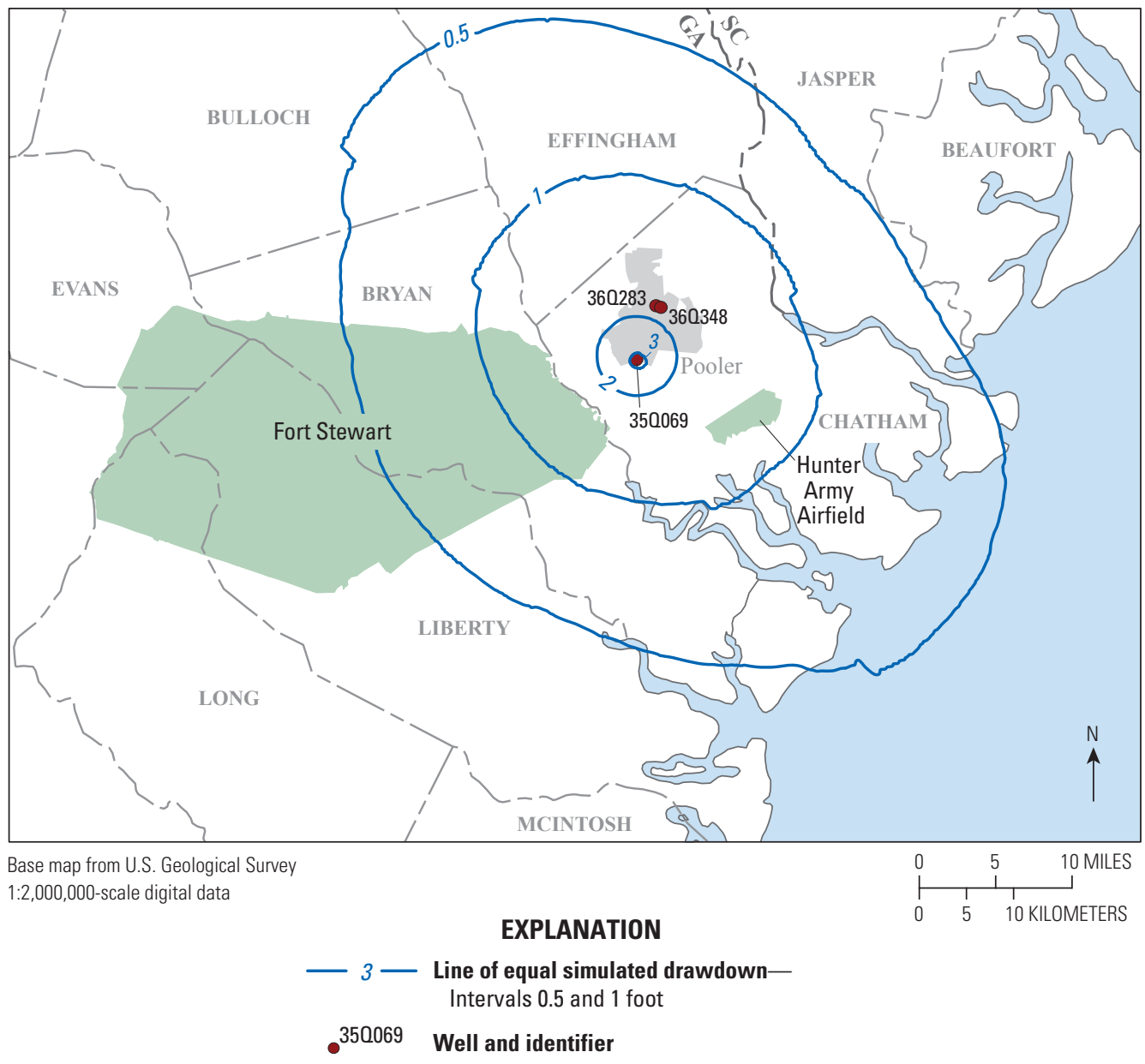

Figure 8B. Simulated steady-state drawdown in the Upper Floridan aquifer for scenario B-pumping Lower Floridan aquifer well 350069 at 1,042 gallons per minute, Pooler and vicinity, Georgia. Maximum drawdown in well 350069 is 3.4 feet. 


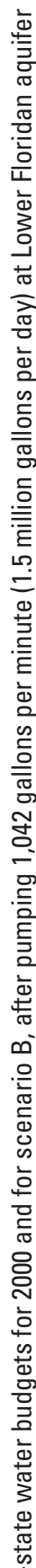

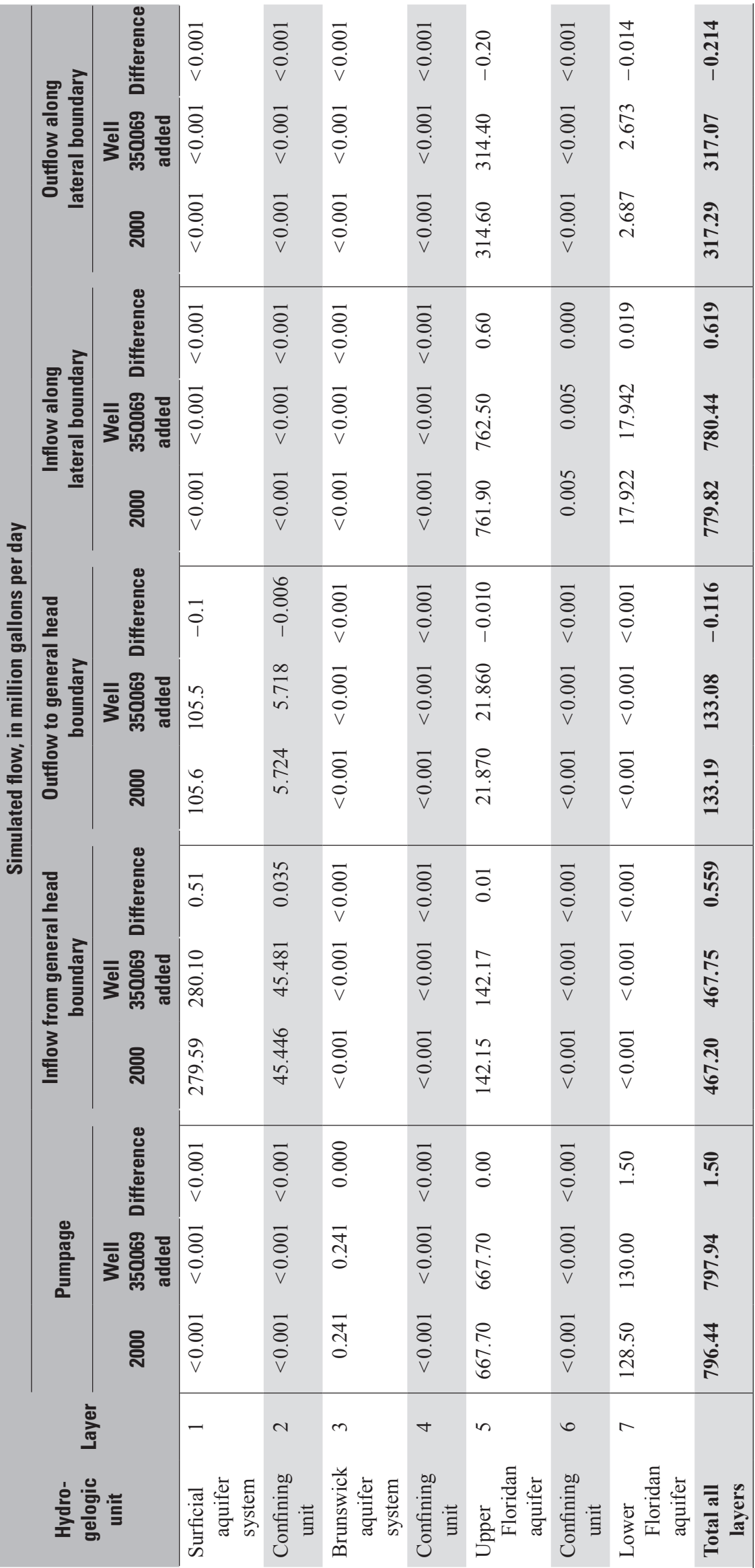


For scenario C, pumping at LFA well 35Q069 was decreased to about one-half the rate of the 72-hr aquifer test, or $390 \mathrm{gal} / \mathrm{min}$ (table 1). Model results for scenario C indicate that drawdown in the LFA reached a maximum of $26 \mathrm{ft}$ and exceeded $1 \mathrm{ft}$ over a $3.64-\mathrm{mi}^{2}$ area (table 1, fig. 9). In the UFA, water levels reached a maximum drawdown of $1.26 \mathrm{ft}$ in response to pumping well 35Q069 and exceeded $1 \mathrm{ft}$ over a 2.66- $\mathrm{mi}^{2}$ area.

Comparison of the steady-state water budgets before and after pumping at well 35Q069 for scenario $\mathrm{C}$ (table 4) revealed a pattern similar to that simulated for scenarios $\mathrm{A}$ and $\mathrm{B}$ (tables 2 and 3), including

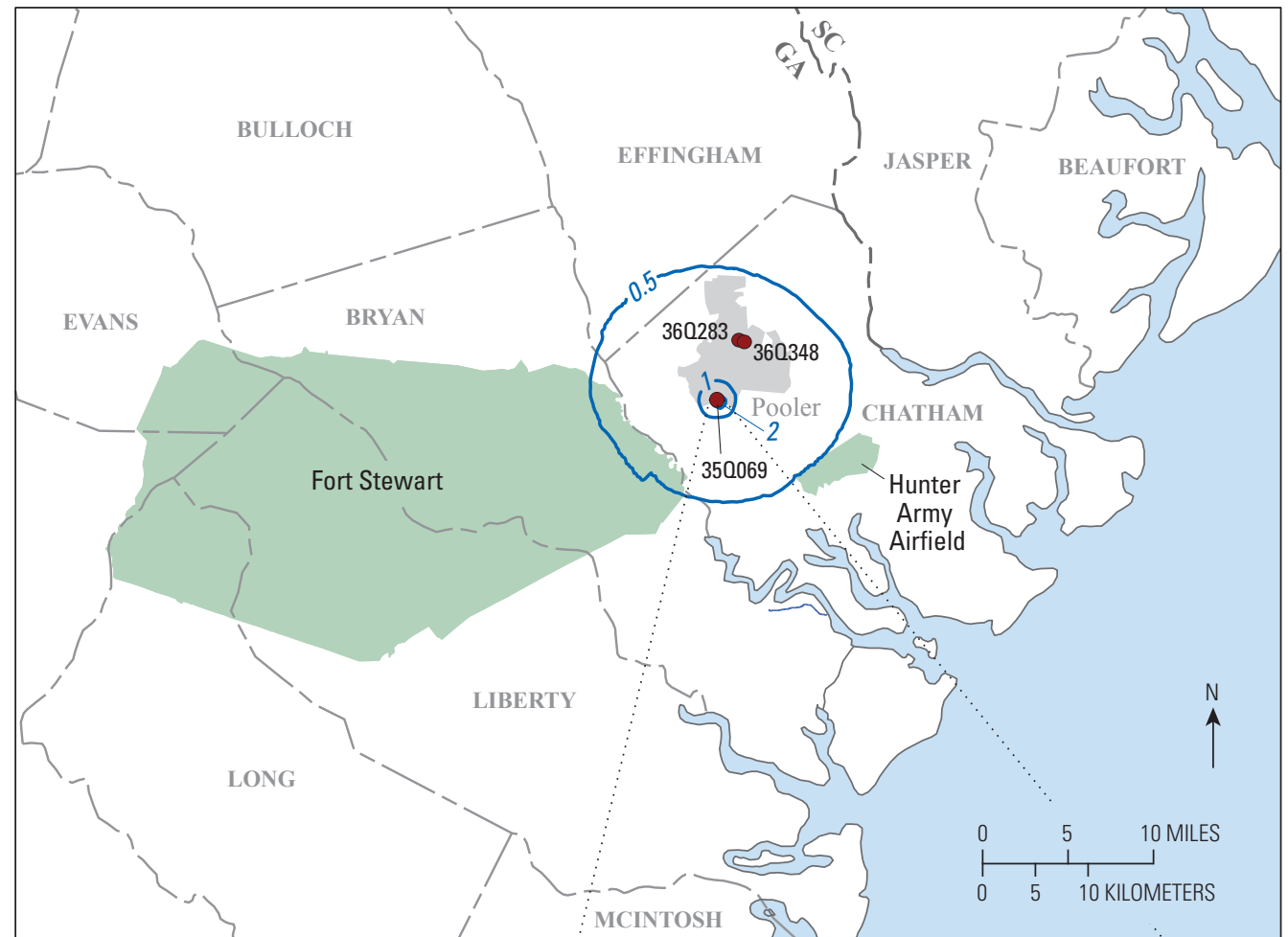

Base map from U.S. Geological Survey

1:2,000,000-scale digital data

\section{EXPLANATION}

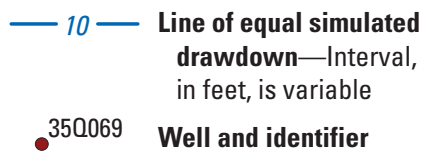

350069 Well and identifier

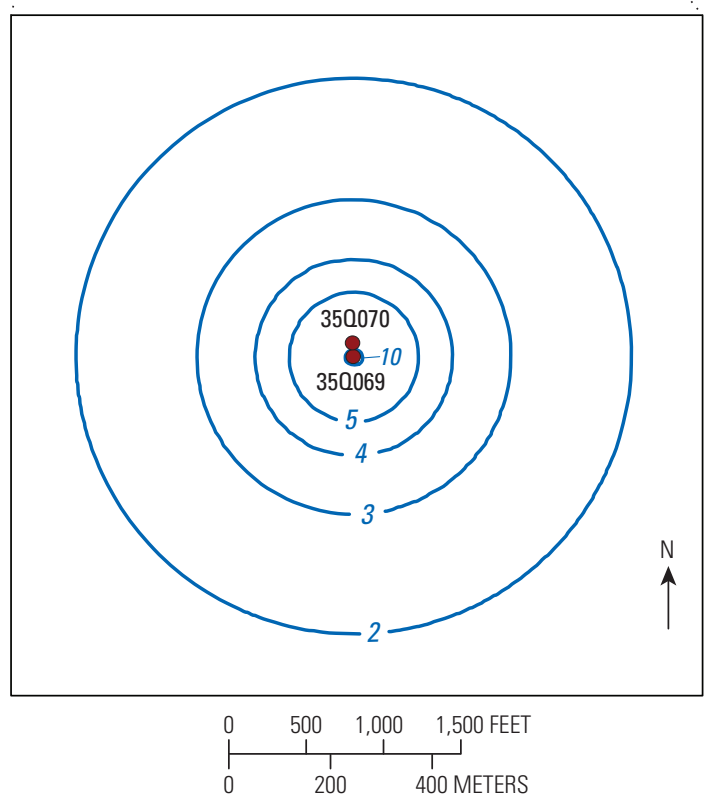

Figure 9A. Simulated steady-state drawdown in the Lower Floridan aquifer for scenario C-pumping Lower Floridan aquifer well 350069 at 390 gallons per minute, Pooler and vicinity, Georgia. Maximum drawdown in well 350069 is 26 feet. 
- Layer 1-A 0.19 Mgal/d increase in inflow (recharge) and $0.05 \mathrm{Mgal} / \mathrm{d}$ decrease in discharge to the general head boundary for a net increase of $0.24 \mathrm{Mgal} / \mathrm{d}$;

- Layer 2-A $0.013 \mathrm{Mgal} / \mathrm{d}$ increase in inflow (recharge) and $0.002 \mathrm{Mgal} / \mathrm{d}$ decrease in discharge to the general head boundary for a net increase of $0.015 \mathrm{Mgal} / \mathrm{d}$;

- Layer 5-A $0.007 \mathrm{Mgal} / \mathrm{d}$ increase in inflow (recharge) from, and a $0.004 \mathrm{Mgal} / \mathrm{d}$ decrease in discharge to, the general head boundary, and a $0.3 \mathrm{Mgal} / \mathrm{d}$ increase in flow from, and $0.05 \mathrm{Mgal} / \mathrm{d}$ decrease in discharge to, lateral specified-head boundaries for a net change of $+0.361 \mathrm{Mgal} / \mathrm{d}$; and

- Layer 7-A $0.007 \mathrm{Mgal} / \mathrm{d}$ increase in flow from, and a $0.005 \mathrm{Mgal} / \mathrm{d}$ decrease in discharge to, lateral specifiedhead boundaries for a net change of $+0.012 \mathrm{Mgal} / \mathrm{d}$.

As was the case for scenarios A and B, 2 percent of the flow to well 35Q069 was provided by lateral boundaries in layer 7, and 98 percent was provided by flow from overlying layers. The identical percentage of leakage contribution for the three scenarios indicates a linear response for pumping conditions ranging from 780 to $1,042 \mathrm{gal} / \mathrm{min}$, which was also indicated by simulated drawdown values for the UFA and LFA.

Comparison of simulated maximum drawdown among scenarios $\mathrm{A}, \mathrm{B}$, and $\mathrm{C}$ indicates that there is a linear response in the UFA and LFA to pumping in the LFA (fig. 10). In scenario A, maximum drawdown in the UFA while pumping the LFA continued at a rate of $780 \mathrm{gal} / \mathrm{min}$ was $2.52 \mathrm{ft}$. Pumping at one-half the scenario A rate (390 gal/ $/ \mathrm{min})$ in scenario $\mathrm{B}$ resulted in $1.26 \mathrm{ft}$ of drawdown in the UFA or one-half the maximum drawdown of scenario A. Similarly, reducing the pumping rate by one-half between scenarios $\mathrm{A}$ and $\mathrm{C}$ resulted in one-half of the maximum drawdown in the LFA for the lower pumping rate $(52.1 \mathrm{ft}$ for scenario A and $26 \mathrm{ft}$ for scenario C). Because of this linear relation, the graph shown in figure 10 can be used to extrapolate amounts of predicted drawdown for a range of pumping values between 390 and 1,042 gal/min.
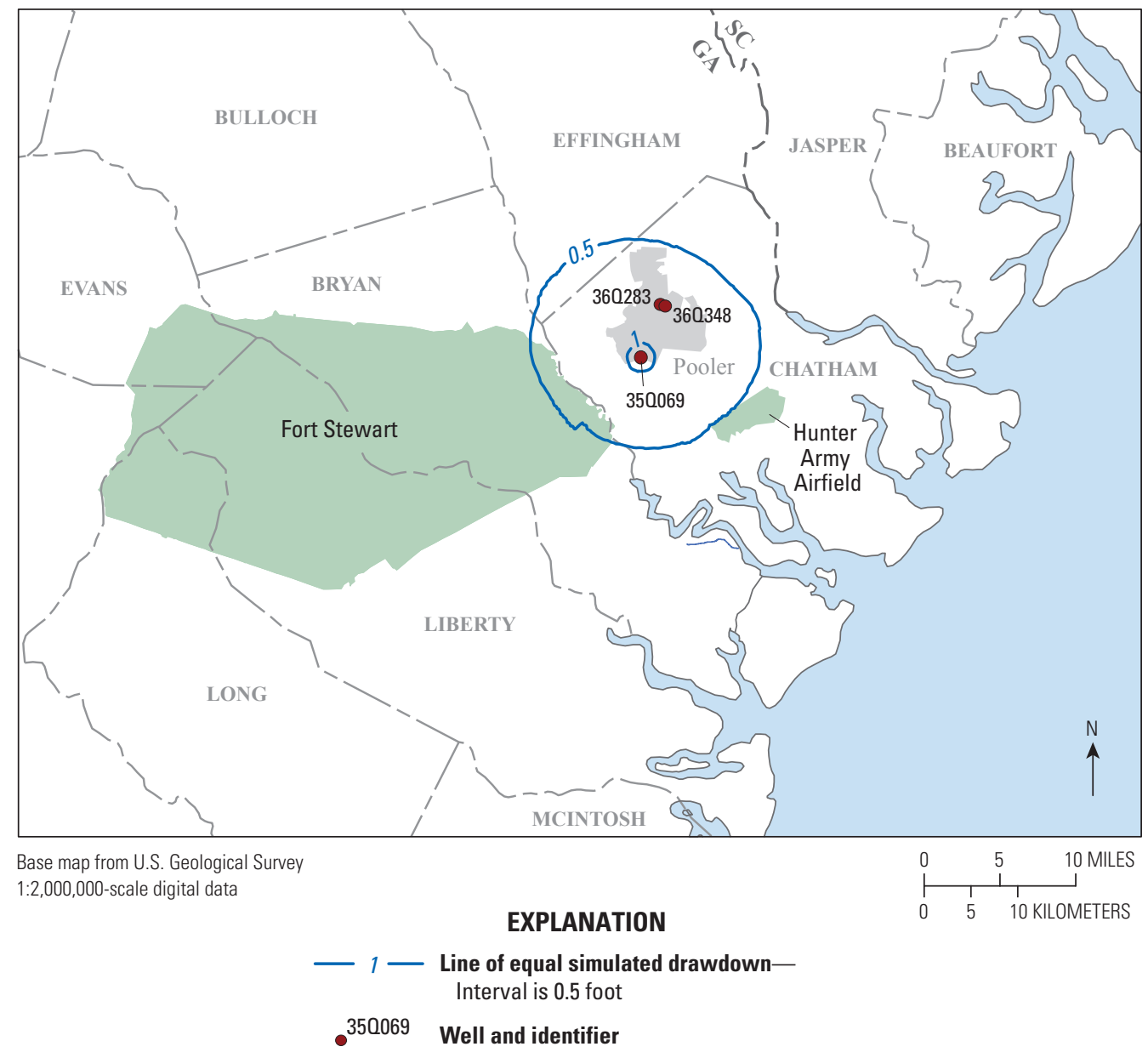

Figure $\mathbf{9 B}$. Simulated steady-state drawdown in the Upper Floridan aquifer for scenario $\mathrm{C}$ - pumping Lower Floridan aquifer well 350069 at 390 gallons per minute, Pooler and vicinity, Georgia. Maximum drawdown in well 350069 is 1.26 feet. 


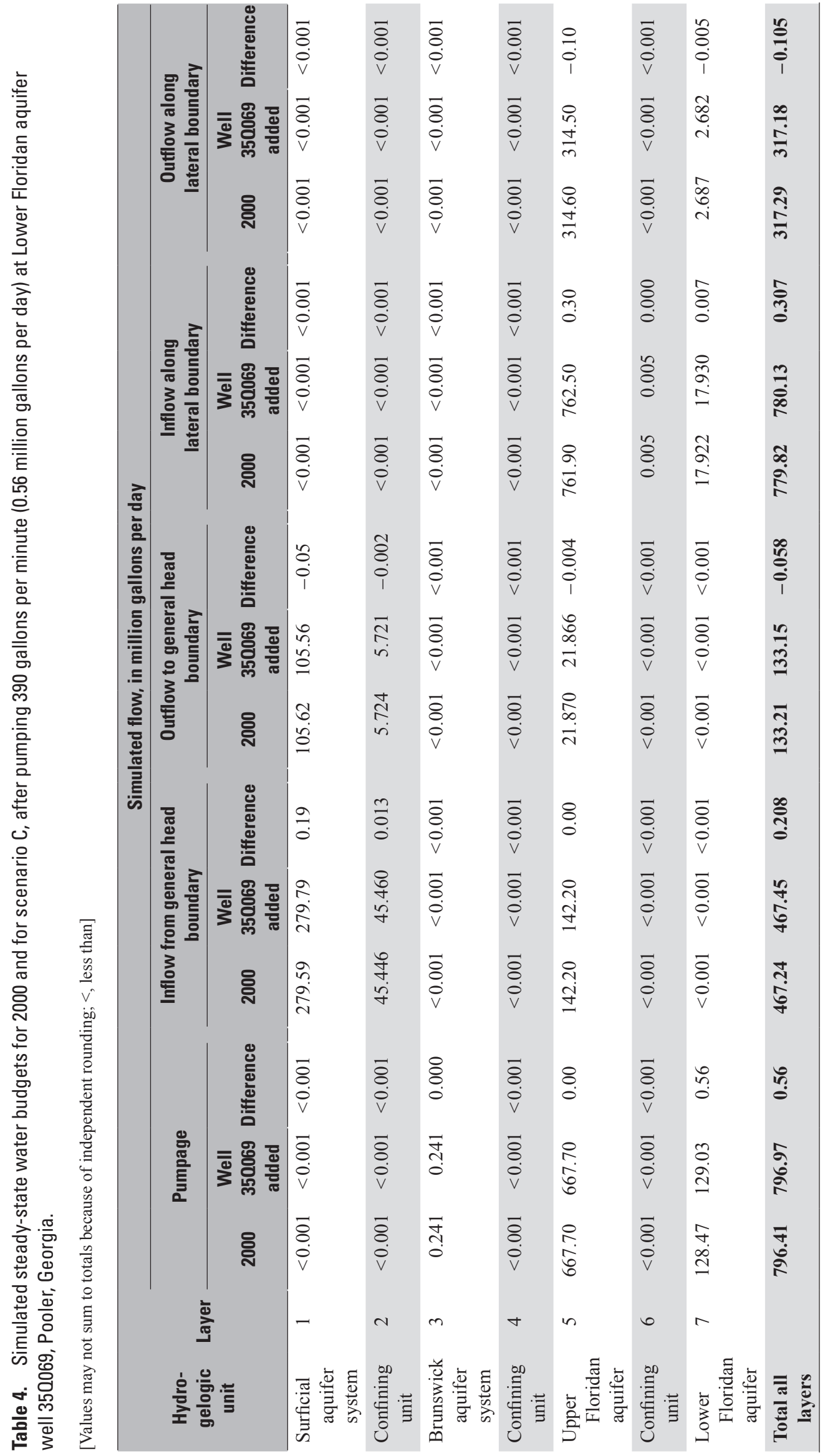




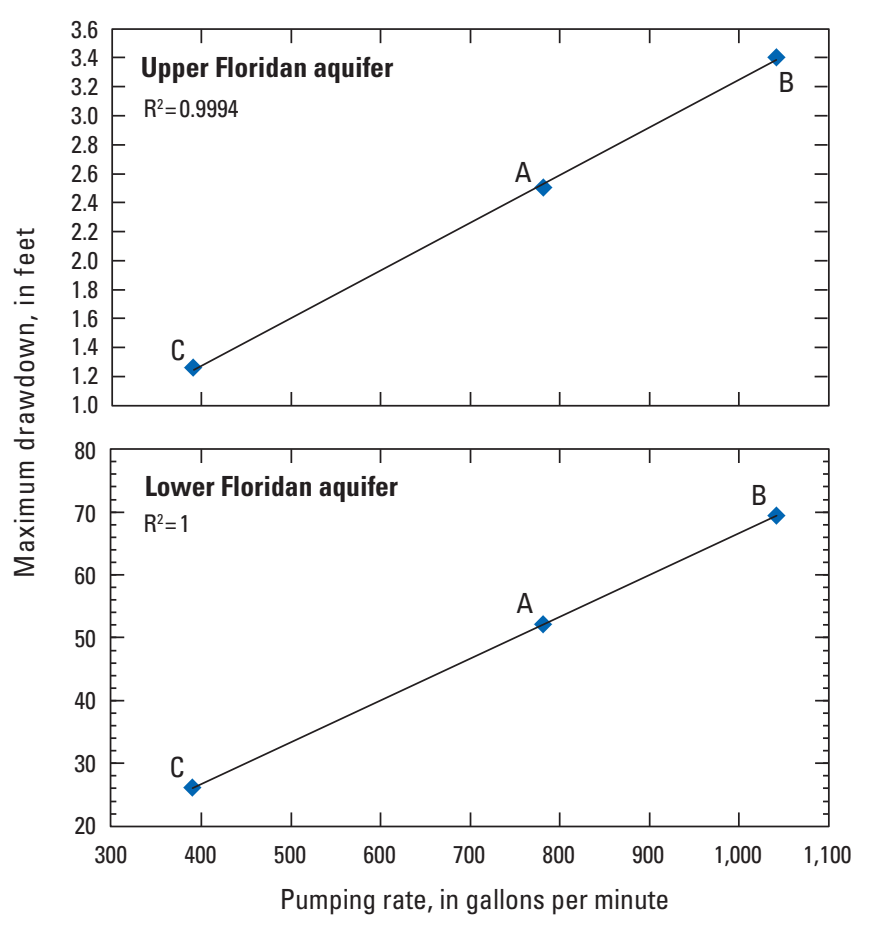

Figure 10. Simulated maximum drawdown in the Upper and Lower Floridan aquifers for scenarios $A$, $\mathrm{B}$, and C, Pooler, Georgia.

\section{Upper Floridan Aquifer Drawdown Offset}

As part of the interim permitting strategy for the LFA, GaEPD established a hydrogeologic-study protocol, which states that a groundwater model shall be used "... to simulate the equivalent Upper Floridan pumping that induces the identical maximum drawdown in the Upper Floridan that would be expected as a result of pumping the Lower Floridan" (Nolton Johnston, Georgia Environmental Protection Division, written commun., January 28, 2003). The amount of equivalent UFA pumping to offset the effect of anticipated LFA pumping would be derived from pumping reductions at existing production wells within a 5-mi radius of the LFA well.

To determine the pumping rate in the UFA that would produce the identical maximum drawdown in the UFA as pumping from the LFA (herein called drawdown offsets), a series of steady-state simulations (scenarios D, E, and F) applying various pumping rates to UFA well 35 Q070 were completed to match UFA drawdown as simulated by scenarios A, B, and C (table 1).

- Scenario D simulated pumping UFA well 35Q070 at a rate of $255 \mathrm{gal} / \mathrm{min}$ and approximated the $2.52 \mathrm{ft}$ maximum drawdown in the UFA resulting from pumping LFA well 35Q069 at $780 \mathrm{gal} / \mathrm{min}$ (scenario A, table 1).
- Scenario E simulated pumping UFA well 35Q070 at a rate of $340 \mathrm{gal} / \mathrm{min}$ and approximated the $3.4 \mathrm{ft}$ maximum drawdown in the UFA resulting from pumping LFA well 35Q069 at 1,042 gal/min (scenario B, table 1).

- Scenario F simulated pumping UFA well 35Q070 at a rate of $128 \mathrm{gal} / \mathrm{min}$ and approximated the $1.26 \mathrm{ft}$ maximum drawdown in the UFA resulting from pumping LFA well $35 \mathrm{Q} 069$ at $390 \mathrm{gal} / \mathrm{min}$ (scenario $\mathrm{C}$, table 1).

Maps of drawdown in the UFA resulting from scenarios D, E, and F are not shown because of the small area affected by pumping. Although it is possible to derive a drawdown offset for the UFA that produces the same maximum drawdown as that induced by leakage from the LFA, that resultant UFA pumping will not produce the same overall drawdown pattern in the UFA as that produced by pumping from the LFA. Scenarios in which LFA well 35Q069 was pumped (scenarios A, B, C; table 1) produced a larger drawdown area in the UFA than scenarios in which UFA well 35Q070 was pumped (scenarios D, E, F; table 1) to offset the maximum UFA drawdown simulated by scenarios A, B, and C. For example, the 0.5 - $\mathrm{ft}$ contour in the UFA corresponding to scenario D (pumping the UFA) encompassed an area of $18.8 \mathrm{mi}^{2}$, whereas the $0.5-\mathrm{ft}$ contour encompassed $833 \mathrm{mi}^{2}$ in the UFA when the LFA was pumped (scenario A).

The large difference in affected area between scenarios involving pumping UFA and LFA wells results from differences in the hydraulic properties of the aquifers and the manner in which water flows to the simulated wells as leakage and from lateral boundaries. Drawdown in the UFA resulting from pumping the LFA has a more gradual lateral gradient and covers a wider area, whereas drawdown resulting from a well pumping directly from the UFA results in a steeper cone of depression covering a smaller area (fig. 11; table 1).

Pumping from the LFA produces a steep hydraulic gradient in the vicinity of the pumped well, progressively decreasing away from the well. This hydraulic gradient results in a high vertical leakage rate near the well. For example, in scenario A, 81 percent of the leakage from the UFA in response to LFA pumping occurred within $1 \mathrm{mi}$ of the pumped well (fig. 7). Beyond this 1-mi area, the high transmissivity of the UFA causes water to flow laterally under a relatively small horizontal hydraulic gradient to the region of large vertical leakage. Drawdown resulting from pumping LFA well 35Q069 extends to lateral specified-head boundaries in both the UFA and LFA, with boundaries in the UFA contributing relatively more flow to pumping in LFA well 35Q069 than boundaries in the LFA for scenarios A, B, and C (tables 2-4). The nearly 10 times higher transmissivity of the UFA enables drawdown to more readily propagate over larger areas than the lower transmissivity LFA. 


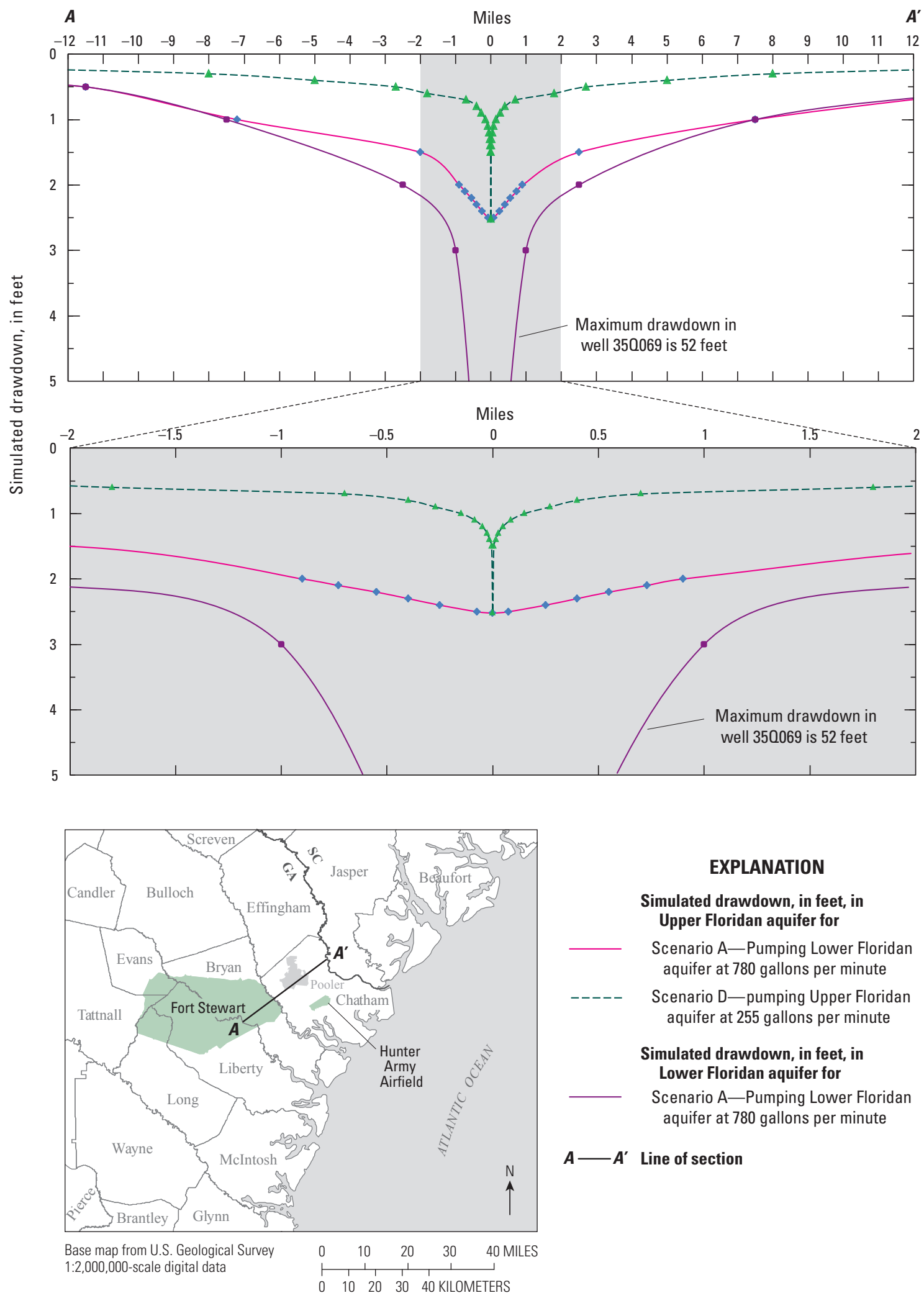

Figure 11. Simulated drawdown in the Upper Floridan aquifer for scenarios $A$ and $D$, and in the Lower Floridan aquifer for scenario A, Pooler and vicinity, Georgia. 


\section{Effects of Pumping Offsets on Groundwater Levels at Pooler}

Reduction of pumping of UFA wells at Pooler to match the maximum simulated drawdown resulting from LFA pumping, as represented by scenarios D, E, and F (table 1), would result in a rise in water levels in the UFA:

- A $255 \mathrm{gal} / \mathrm{min}$ decrease would result in a maximum water level rise of $2.5 \mathrm{ft}$, with rises greater than $0.5 \mathrm{ft}$ extending over a $18.8-\mathrm{mi}^{2}$ area;

- A $340 \mathrm{gal} / \mathrm{min}$ decrease would result in a maximum water level rise of $3.4 \mathrm{ft}$, with rises above $0.5 \mathrm{ft}$ extending over a 93.2- $\mathrm{mi}^{2}$ area; and

- A $128 \mathrm{gal} / \mathrm{min}$ decrease would result in a maximum water level rise of $1.26 \mathrm{ft}$, with rises above $0.5 \mathrm{ft}$ extending over a $0.05-\mathrm{mi}^{2}$ area.

To evaluate the combination of these pumping reductions with the addition of pumping from the LFA, three model scenarios were developed and executed to assess the effect of pumping redistribution on current groundwater conditions at Pooler. For each scenario, LFA well 35Q069 was pumped at different rates, and pumping at existing Pooler supply wells, located about $3.7 \mathrm{mi}$ northward (see locations, fig. 12), was reduced according to UFA drawdown offsets as simulated by scenarios D, E, and F. Because offsetting existing UFA pumping by 98 percent of the LFA pumping rate (representing UFA leakage to the LFA) would result in virtually no gain in production at Pooler, a scenario was not run to assess the effects of such a pumping change. The three scenarios tested and specifications (table 1) are listed below.

- Scenario G (fig. 12) — Simulated pumping of LFA well 35Q069 at an average daily rate of $780 \mathrm{gal} / \mathrm{min}$ (1.12 Mgal $/ \mathrm{d})$ and reduction of pumping rates in existing UFA Pooler supply wells by $255 \mathrm{gal} / \mathrm{min}$ $(0.367 \mathrm{Mgal} / \mathrm{d})$ or 32 percent of the pumping rate at LFA well 35Q069. The reduction in withdrawals from the UFA represents the rate required to match the maximum UFA drawdown simulated near LFA well 35Q069 as was computed for scenario D.

- Scenario H (fig. 13) —-Simulated pumping of LFA well 35Q069 at an average daily rate of $1,042 \mathrm{gal} / \mathrm{min}(1.5 \mathrm{Mgal} / \mathrm{d})$ and reduction of pumping in existing UFA Pooler supply wells by $340 \mathrm{gal} / \mathrm{min}$ $(0.490 \mathrm{Mgal} / \mathrm{d})$ or 32 percent of the pumping rate at well 35Q069. The reduction in withdrawals from the UFA represents the rate required to match the maximum UFA drawdown simulated near LFA well 35Q069, as was computed for scenario F.
- Scenario I (fig. 14) - Simulated pumping of LFA well 35Q069 at an average daily rate of $390 \mathrm{gal} / \mathrm{min}(0.565 \mathrm{Mgal} / \mathrm{d})$ and reduction of pumping in existing UFA Pooler supply wells by $128 \mathrm{gal} / \mathrm{min}(0.184 \mathrm{Mgal} / \mathrm{d})$ or 32 percent of the pumping rate at well 35Q069. The reduction in withdrawals from the UFA represents the rate required to match the maximum UFA drawdown simulated near LFA well 35Q069, as was computed for scenario $\mathrm{E}$.

Decreases in the magnitude and areal extent of drawdown in the UFA in response to pumping the LFA well were realized for scenarios that simulated drawdown offsets (reductions) for the existing UFA wells at Pooler (scenarios $\mathrm{G}, \mathrm{H}$, and I) when compared with the magnitude and extent of drawdown resulting from scenarios that did not simulate drawdown offsets for the existing UFA wells at Pooler (scenarios A, B, and C; table 1). For scenario A, pumping LFA well 35Q069 at a rate of $780 \mathrm{gal} / \mathrm{min}$ without drawdown offsets in the UFA resulted in UFA drawdown that exceeded $0.5 \mathrm{ft}$ over a $833-\mathrm{mi}^{2}$ area and a maximum drawdown of $2.52 \mathrm{ft}$ near wells 35Q069 and 35Q070 (fig. 6). In contrast, for scenario $\mathrm{G}$, in which the LFA was pumped at the same rate and a $255 \mathrm{gal} / \mathrm{min}$ drawdown offset in existing Pooler wells was implemented, simulated maximum UFA drawdown was $2.1 \mathrm{ft}$ near well 35Q069, and the area in which drawdown exceeded $0.5 \mathrm{ft}$ covered $357 \mathrm{mi}^{2}$ (fig. 12; table 1).

Simulated maximum drawdown in the UFA for scenario B reached $3.4 \mathrm{ft}$ near well 35Q069, and the simulated 0.5 -ft drawdown contour covered an area of 1,395 $\mathrm{mi}^{2}$ (fig. 8; table 1). In contrast, for scenario $\mathrm{H}$, which applied a $340 \mathrm{gal} / \mathrm{min}$ drawdown offset to the existing Pooler wells, simulated maximum UFA drawdown totaled $2.8 \mathrm{ft}$ near well 35Q069, and the area in which drawdown exceeded $0.5 \mathrm{ft}$ covered $652 \mathrm{mi}^{2}$ (fig. 13).

For scenario C, simulated maximum drawdown in the LFA was $26 \mathrm{ft}$ near well 36Q069, and the simulated $0.5-\mathrm{ft}$ drawdown contour covered an area of $163 \mathrm{mi}^{2}$ (fig. 9; table 1). In contrast, for scenario I, in which the LFA was pumped at the same rate as scenario $\mathrm{C}$ and pumping in existing Pooler wells was reduced by $128 \mathrm{gal} / \mathrm{min}$, simulated maximum UFA drawdown was $1 \mathrm{ft}$ near well 35Q069, and the area in which simulated drawdown exceeded $0.5 \mathrm{ft}$ covered $28.4 \mathrm{mi}^{2}$ (fig. 14; table 1).

Simulated potentiometric surfaces for the UFA from scenarios $\mathrm{G}, \mathrm{H}$, and I resulted in no noticeable changes in the regional configuration of implied groundwater-flow directions for the UFA when compared with a base case representing year 2000 conditions (fig. 15). Groundwater flow in the region remained dominated by a large cone of depression centered over the Savannah, Ga., area. 

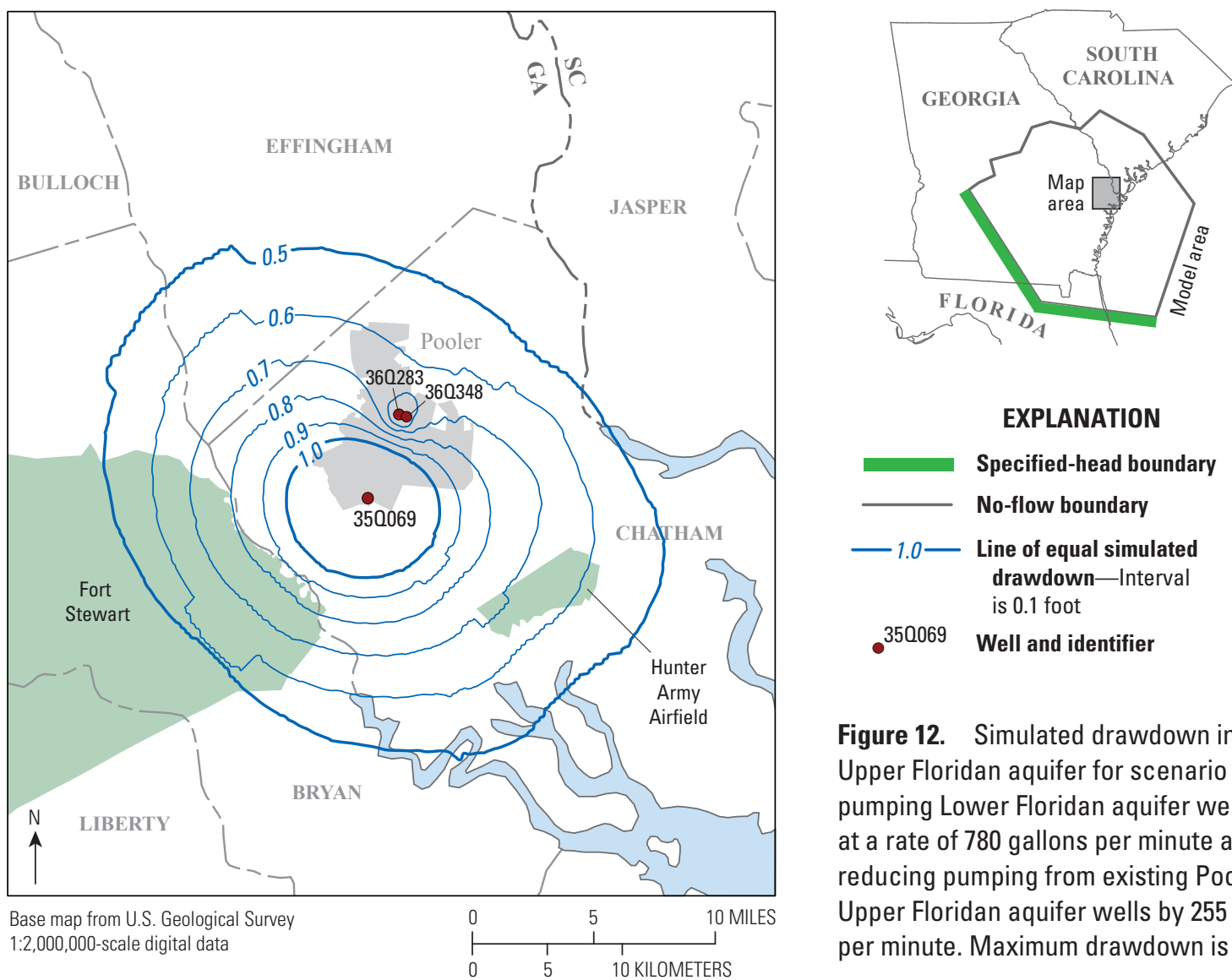

\section{EXPLANATION}

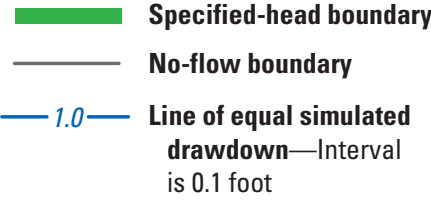

350069 Well and identifier

Figure 12. Simulated drawdown in the Upper Floridan aquifer for scenario $\mathrm{G}$ pumping Lower Floridan aquifer well 350069 at a rate of 780 gallons per minute and reducing pumping from existing Pooler Upper Floridan aquifer wells by 255 gallons per minute. Maximum drawdown is 2.1 feet.
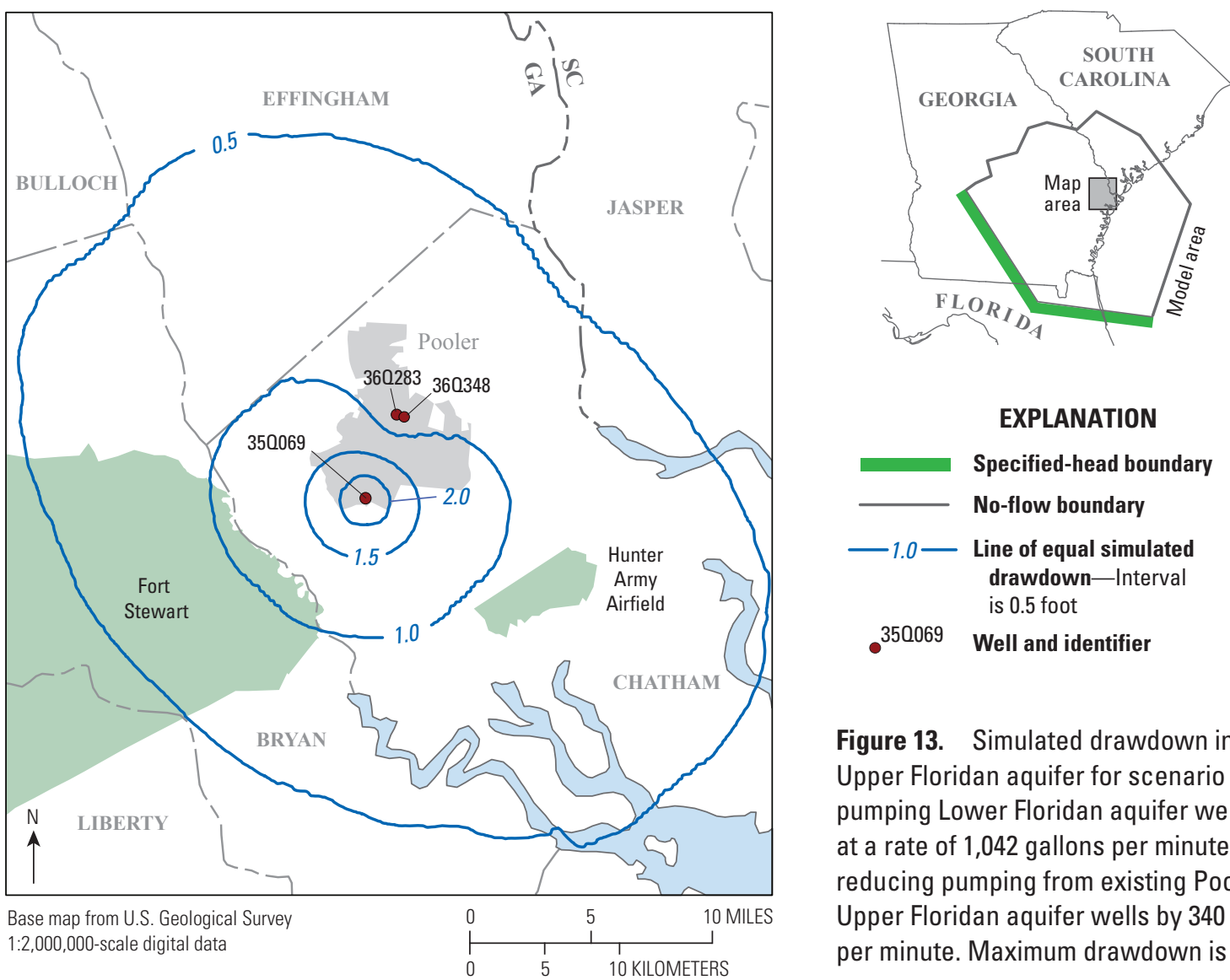

\section{EXPLANATION}

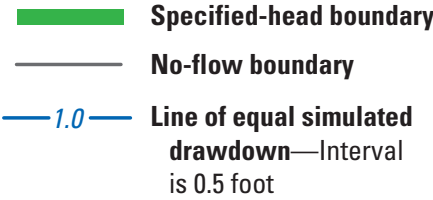

350069 Well and identifier

Figure 13. Simulated drawdown in the Upper Floridan aquifer for scenario $\mathrm{H}-$ pumping Lower Floridan aquifer well 350069 at a rate of 1,042 gallons per minute and reducing pumping from existing Pooler Upper Floridan aquifer wells by 340 gallons per minute. Maximum drawdown is 2.8 feet. 


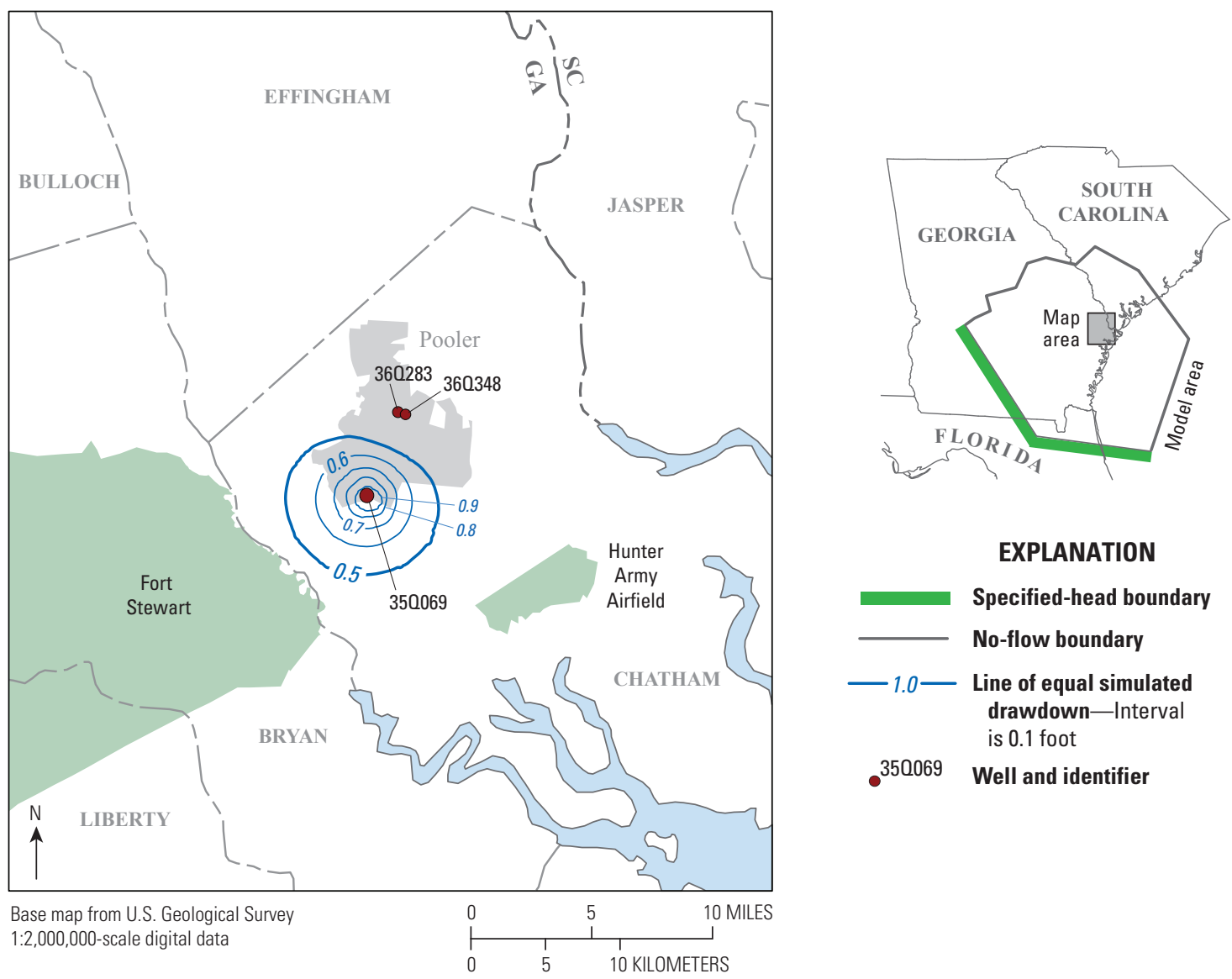

Figure 14. Simulated drawdown in the Upper Floridan aquifer for scenario l-pumping Lower Floridan aquifer well 350069 at a rate of 390 gallons per minute and reducing pumping from existing Pooler Upper Floridan aquifer wells by 128 gallons per minute. Maximum drawdown is 1 foot. 

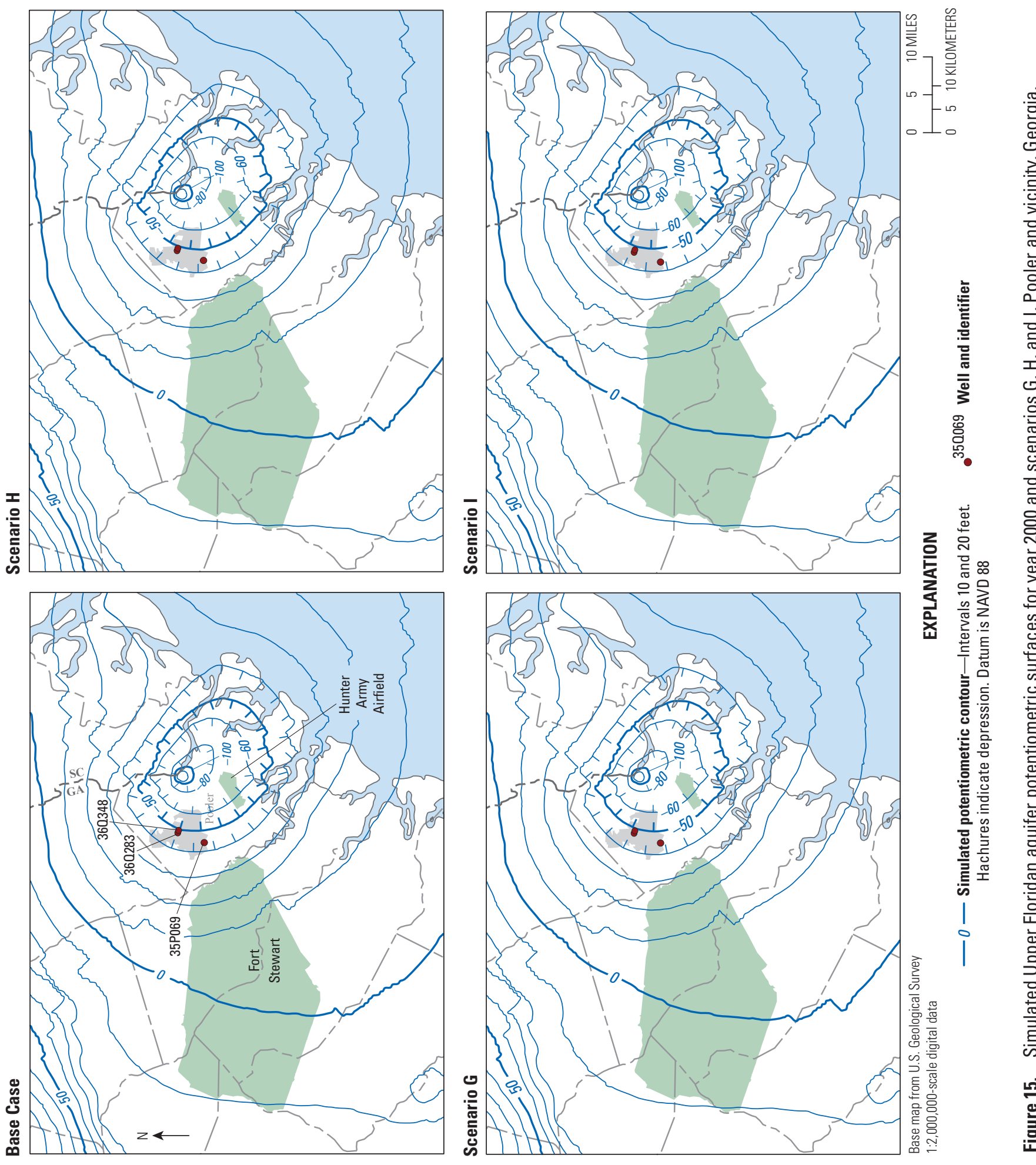


\section{Model Sensitivity}

To assess the relative importance of model parameters to groundwater levels and flow rates, Payne and others (2005) provided a comprehensive sensitivity analysis of the original regional model for both 1980 and 2000 simulations. Their evaluation included determination of composite-scaled sensitivities for pumping rate, $\mathrm{K}_{h}$ and $\mathrm{K}_{\mathrm{v}}$ for each hydraulicproperty zone, and the conductance of the general head boundary using procedures described by Hill (1998). Results of this analysis indicate that the model is most sensitive to pumping variations by a wide margin, followed by $\mathrm{K}_{\mathrm{h}}$ of several zones in layer 5 (UFA). $\mathrm{K}_{\mathrm{v}}$ of the LFCU (layer 6) was ranked near the last parameter (20th out of 23 parameters).

To provide insight into the sensitivity of simulated head and water-budget components to modified hydraulic-property zones in the revised model, a series of model simulations were run whereby the LFA was pumped at a rate of $780 \mathrm{gal} / \mathrm{min}$ (same as scenario A), and the hydraulic parameter was varied by factors of $0.1,0.5,2.0$, and 10.0. $\mathrm{K}_{\mathrm{h}}$ and $\mathrm{K}_{\mathrm{v}}$ of the UFA were varied in the area of hydraulic-property zone $\mathrm{F} 13 . \mathrm{K}_{\mathrm{h}}$ and $\mathrm{K}_{\mathrm{v}}$ of the LFA were adjusted in the area of hydraulic-property zone LF2, and $\mathrm{K}_{\mathrm{h}}$ and $\mathrm{K}_{\mathrm{v}}$ of the LFCU were varied in area of hydraulic-property zone LFC2 (see appendix table 1-1 and fig. 1-3). For each simulation, the following simulated values were recorded (figs. 16-18; table 5):

- Maximum drawdown in the UFA and LFA,

- Total net flow from the general head boundaries,

- Total net flow from the lateral specified-head boundaries, and

- Total net downward flow (leakage) from the LFCU to the LFA.

Major results of the sensitivity analysis are

- Increases in $\mathrm{K}_{\mathrm{h}}$ and $\mathrm{K}_{\mathrm{v}}$ of the LFA in zone LF2 (fig. 16) resulted in lower drawdown in both the UFA and LFA, a slight decrease in flow from model general head boundaries (recharge), and a slight increase in flow from lateral specified-head boundaries in the UFA and LFA. Decreasing $\mathrm{K}_{\mathrm{h}}$ and $\mathrm{K}_{\mathrm{v}}$ resulted in the opposite response for each simulated value. Changing $\mathrm{K}_{h}$ and $\mathrm{K}_{\mathrm{v}}$ of the LFA had virtually no effect on downward flow (leakage) from the LFCU to the LFA.

- Increases in $\mathrm{K}_{\mathrm{h}}$ and $\mathrm{K}_{\mathrm{v}}$ of the UFA in zone F13 (fig. 17) resulted in lower drawdown in both the UFA and LFA, decreased flow from the general head boundaries, and increased flow from lateral specified-head boundaries in the UFA and LFA. Decreasing $\mathrm{K}_{h}$ and $\mathrm{K}_{\mathrm{v}}$ resulted in the opposite response for each simulated value. As was the case with the LFA, changing $\mathrm{K}_{\mathrm{h}}$ and $\mathrm{K}_{\mathrm{v}}$ of the UFA had virtually no effect on downward flow (leakage) from the LFCU to the LFA.
- Increases in $\mathrm{K}_{\mathrm{h}}$ and $\mathrm{K}_{\mathrm{v}}$ of the LFCU in zone LFC2 (fig. 18) resulted in decreased maximum drawdown in the LFA and increased maximum drawdown in the UFA. Decreasing $\mathrm{K}_{\mathrm{h}}$ and $\mathrm{K}_{\mathrm{v}}$ resulted in the opposite response for each simulated drawdown value. Changing $\mathrm{K}_{\mathrm{h}}$ and $\mathrm{K}_{\mathrm{v}}$ of the LFCU had virtually no effect on flows from general head boundaries, flows from lateral specified-head boundaries in the UFA and LFA, or downward flow (leakage) from the LFCU to the LFA.

The magnitude of the effects of an increase or decrease in each hydraulic parameter on specified-head and general head boundaries and on leakage was minor (less than 1.4 percent change; table 5). Changes in hydraulic parameters had a greater effect on maximum drawdown in the UFA and LFA.

Results of the sensitivity analysis indicate that $\mathrm{K}_{\mathrm{h}}$ and $\mathrm{K}_{\mathrm{v}}$ of the UFA and LFA are the most important parameters in model simulations. $\mathrm{K}_{\mathrm{h}}$ and $\mathrm{K}_{\mathrm{v}}$ of the LFCU had little effect on simulated leakage and groundwater levels because the model is relatively insensitive to these parameters.

Varying $\mathrm{K}_{\mathrm{h}}$ and $\mathrm{K}_{\mathrm{v}}$ of the LFA by an order of magnitude resulted in less than a 1-percent effect on specified-head and general head boundaries and on leakage between the LFCU and LFA. Simulated drawdown in the UFA and LFA showed a more pronounced response to changes in $\mathrm{K}_{\mathrm{h}}$ and $\mathrm{K}_{\mathrm{v}}$ of the LFA. Reducing $\mathrm{K}_{\mathrm{h}}$ and $\mathrm{K}_{\mathrm{v}}$ of the LFA by an order of magnitude resulted in increased maximum drawdown in the UFA (+162.7 percent) and LFA (+843 percent). Increasing the $\mathrm{K}_{\mathrm{h}}$ and $\mathrm{K}_{\mathrm{v}}$ of the LFA by an order of magnitude resulted in a 93 percent decrease in drawdown in the LFA and a rise in water levels in the UFA despite pumping from the LFA at $780 \mathrm{gal} / \mathrm{min}$. This rise results from a decrease in drawdown owing to the increased influx of water from surrounding hydraulic-property zones into the area of zone LF2.

As was the case for the LFA, varying $K_{h}$ and $K_{v}$ of the UFA by an order of magnitude resulted in little effect (less than 1 to 1.4 percent) on specified-head and general head boundaries and on leakage between the LFCU and LFA. Decreasing $\mathrm{K}_{\mathrm{h}}$ and $\mathrm{K}_{\mathrm{v}}$ of the UFA by an order of magnitude resulted in increased maximum drawdown in the UFA (+757.5 percent) and in the LFA (+128.9 percent). Increasing the $\mathrm{K}_{\mathrm{h}}$ and $\mathrm{K}_{\mathrm{v}}$ of the UFA by an order of magnitude, resulted in a 15.5 percent decrease in drawdown in the LFA and a rise in water levels in the UFA despite pumping from the LFA at $780 \mathrm{gal} / \mathrm{min}$. This rise resulted from a decrease in drawdown owing to the increased influx of water from surrounding hydraulic-property zones into the area of zone F13.

Varying the $\mathrm{K}_{h}$ and $\mathrm{K}_{\mathrm{v}}$ of the LFCU by an order of magnitude had virtually no effect on flow from model boundaries or leakage. Increasing $\mathrm{K}_{\mathrm{h}}$ and $\mathrm{K}_{\mathrm{v}}$ of the LFCU by an order of magnitude resulted in a 3.2 percent increase in maximum drawdown in the UFA and an 11.4 percent decrease in the LFA. Reducing $\mathrm{K}_{\mathrm{h}}$ and $\mathrm{K}_{\mathrm{v}}$ by an order of magnitude resulted in a 12.7 percent decrease in maximum drawdown in the UFA and 7.9 percent increase in the LFA. 

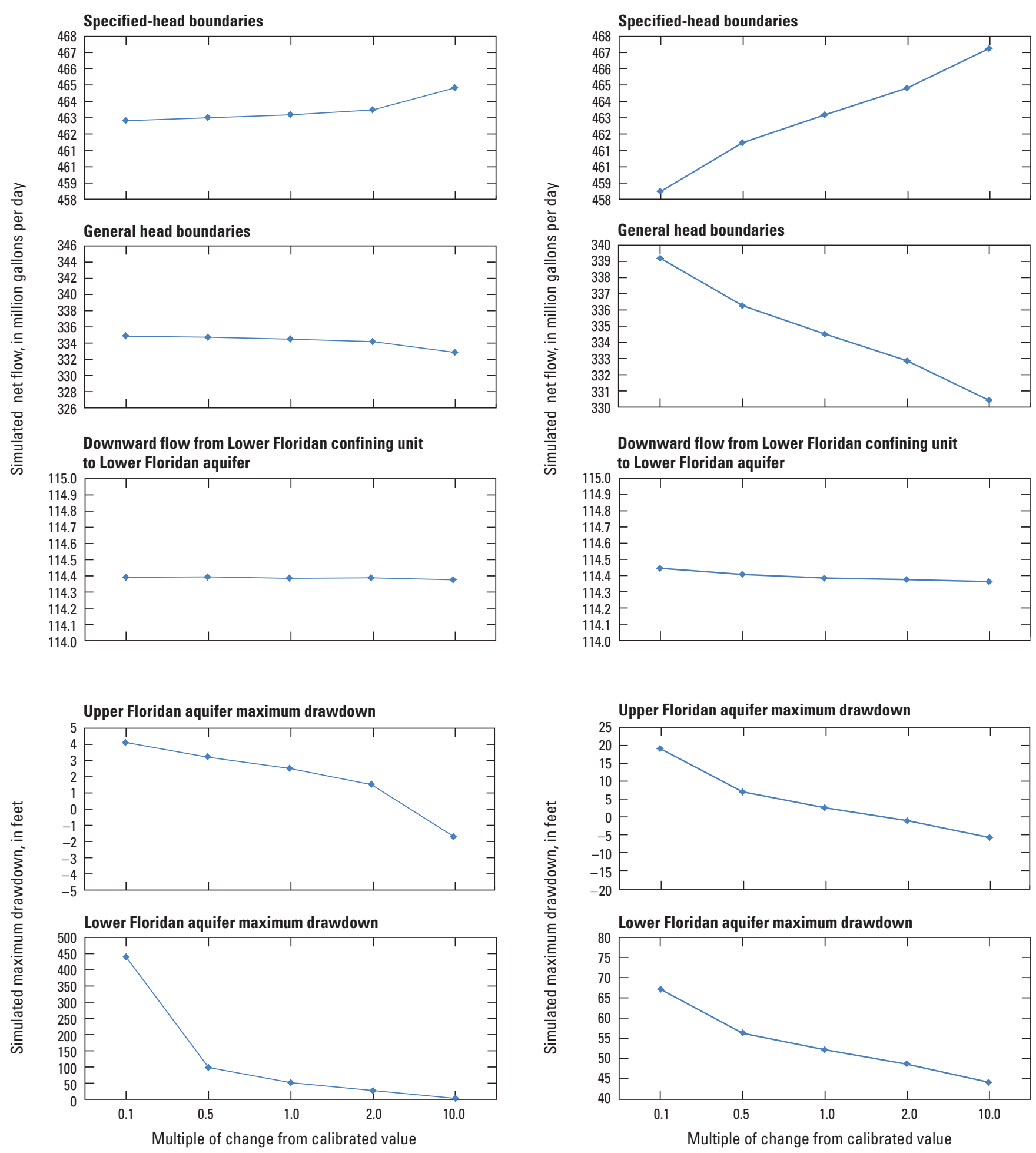

Figure 16. Sensitivity of simulated maximum drawdown in the Upper and Lower Floridan aquifers and simulated net flow from specified-head and general head boundaries, and between the Lower Floridan confining unit and Lower Floridan aquifer to changes in horizontal hydraulic conductivity of the Lower Floridan aquifer in hydraulic-property zone LF2.

Figure 17. Sensitivity of simulated maximum drawdown in the Upper and Lower Floridan aquifers and simulated net flow from specified-head and general head boundaries, and between the Lower Floridan confining unit and Lower Floridan aquifer to changes in horizontal hydraulic conductivity of the Upper Floridan aquifer in hydraulic-property zone F13. 

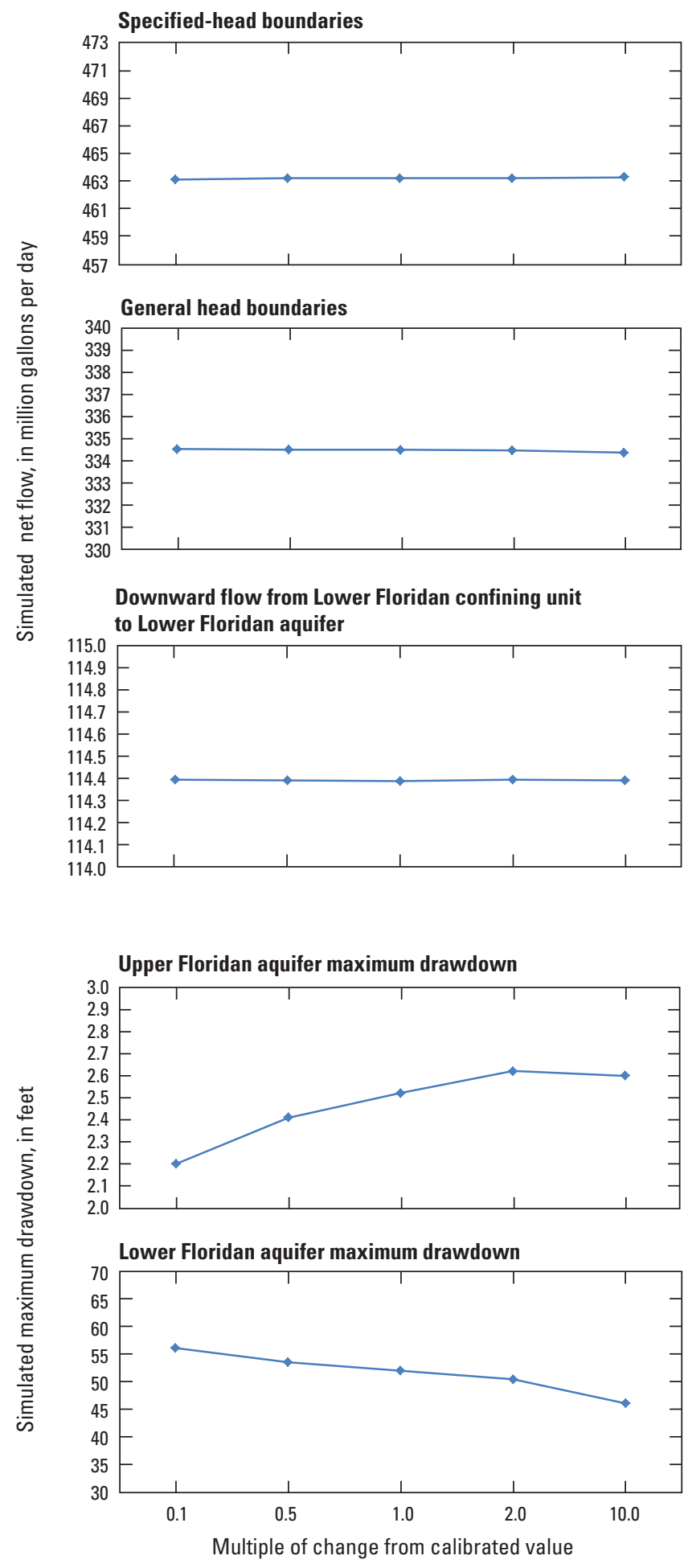

Figure 18. Sensitivity of simulated maximum drawdown in the Upper and Lower Floridan aquifers and simulated net flow from specified-head and general head boundaries, and between the Lower Floridan confining unit and Lower Floridan aquifer to changes in horizontal hydraulic conductivity of the Lower Floridan confining unit in hydraulic-property zone LFC2.

\section{Limitations of Analysis}

Analysis of the effects of pumping the LFA on water levels in the UFA are limited by the accuracy of field data, including possible errors and uncertainty in water-level measurements, hydraulic properties, and pumpage (not quantified in this report). Although water-level data were filtered to minimize or eliminate effects of local interferences, such as tides, barometric pressure, and pumping (Gonthier, 2012), some interferences could remain and affect recorded levels to some degree and, thus, affect computed hydraulic properties.

The revised model of Payne and others (2005) reasonably depicts changes in groundwater levels resulting from pumping the LFA at Pooler at a rate of $780 \mathrm{gal} / \mathrm{min}$. Results are limited by the same model assumptions and design as described by Payne and others (2005). These include inaccuracies in the conceptual model of groundwater flow; approximations made in representing the physical properties of the flow system and errors inherent in estimating the spatial distribution of these properties; approximations made in the formulation and application of model boundary and initial conditions; errors associated with numerical approximation and solution of the mathematical model of the flow system; and assumptions made in using the models to predict the future behavior of the flow system, such as no variations in recharge rates or boundary heads.

The variably spaced grid used in the revised model contains aspect ratios between row and column dimensions as large as 1,630:1, which can lead to numerical errors (de Marsily, 1986, p. 351). Fortunately, these large aspect ratio grid cells occur only in areas distant from Pooler and have little effect on simulated results in the area (see calibration results in the appendix).

Sensitivity analysis of the revised model indicates that drawdown in the UFA and LFA is most sensitive to variations in $\mathrm{K}_{\mathrm{h}}$ and $\mathrm{K}_{\mathrm{v}}$ of the UFA and LFA in hydraulic-property zones F13 and LF2, respectively. Errors in computation of these values would have an effect on simulated maximum drawdown and associated drawdown offset computations.

Simulated rates of interaquifer leakage and drawdown in the UFA can differ from actual rates because of the influence of specified-head and general head boundaries, which allow an unlimited amount of water exchange between the model and the aquifer region that extends beyond the model grid. This unlimited supply can affect simulated drawdown and rates of interaquifer leakage. Finally, although the revised groundwater-flow model reasonably simulates steady-state conditions, use of transient simulation would provide insight into drawdown and groundwater leakage over time. 


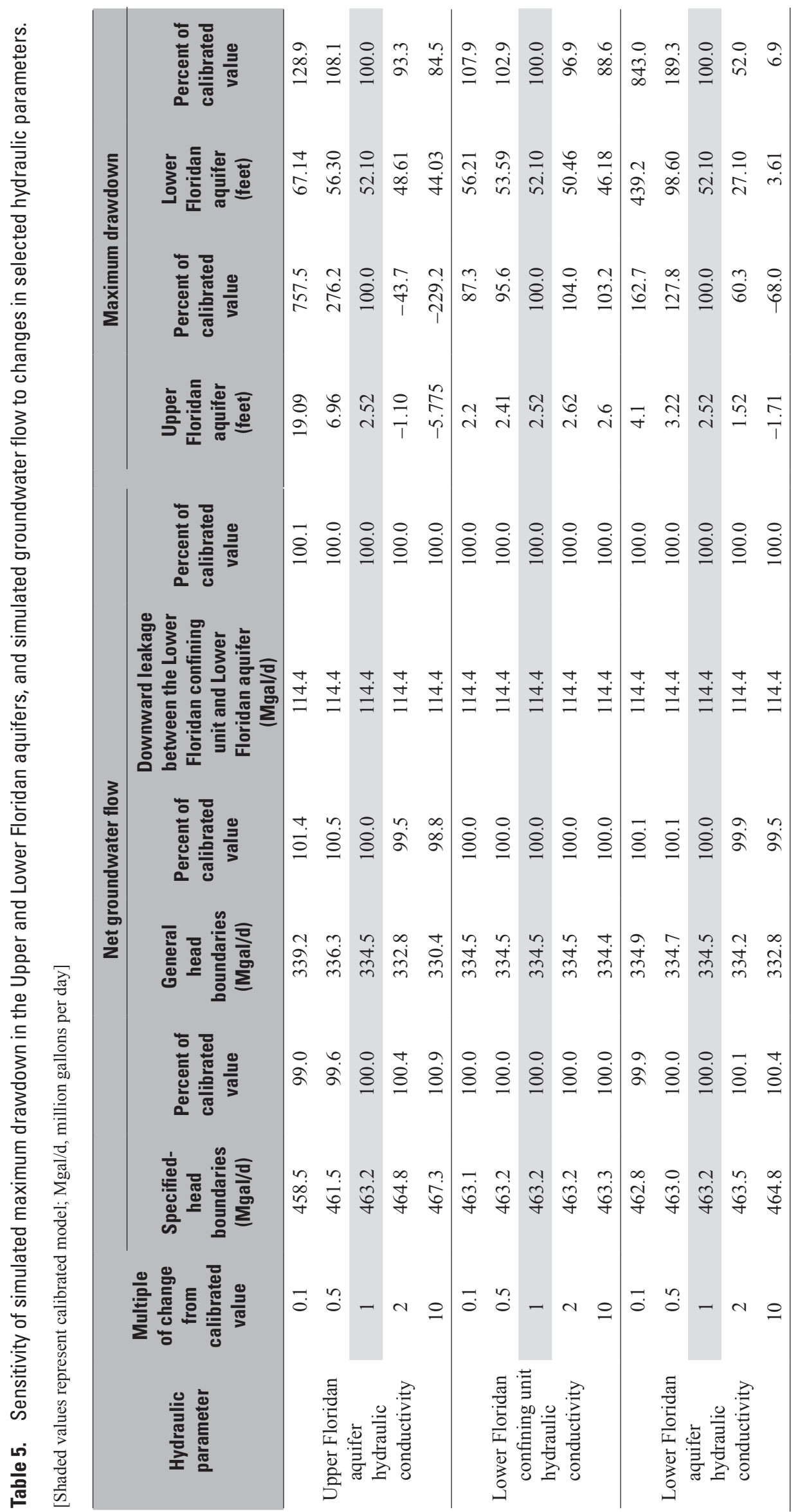




\section{Summary and Conclusions}

Model simulation was used to assess the potential effects on the Upper Floridan aquifer (UFA) of pumping at a new well, completed in the Lower Floridan aquifer (LFA) and located at the City of Pooler, Georgia. An existing regional groundwater-flow model that simulated steady-state flow in the Floridan aquifer system was modified with a fine spatial resolution and incorporates detailed hydrogeologic information resulting from field investigations at Pooler and existing wells in the area. Model scenarios were completed whereby the LFA was pumped at rates of 780 gallons per minute (gal/min), the approximate rate of a 72-hour (hr) aquifer test; $1,042 \mathrm{gal} / \mathrm{min}$; and $390 \mathrm{gal} / \mathrm{min}$, one-half the rate of the $72-\mathrm{hr}$ test. The major conclusions are listed below.

- Long-term pumping at a rate of $780 \mathrm{gal} / \mathrm{min}$ from the LFA would cause a simulated maximum drawdown of about 2.52 feet (ft) in the UFA, with drawdown exceeding $1 \mathrm{ft}$ over a 163-square-mile $\left(\mathrm{mi}^{2}\right)$ area. Induced vertical leakage from the UFA provided about 98 percent of the water to the LFA; the area within 1 mile (mi) of the pumped well supplied about 81 percent of the water pumped. The effects of this leakage on the UFA, although slight with regard to drawdown in the UFA, extend into the Coastal Plain beyond Pooler because of the relatively large, about 10:1, contrast in the water-transmitting ability, or transmissivity, of the UFA compared with that of the LFA.

- Simulated pumping changed regional water-budget components slightly and redistributed flow among model layers, namely increasing inflow to, and decreasing outflow from, lateral boundaries in the UFA and LFA, and increasing inflow (recharge) from the general head boundary to outcrop areas in model layers 1,2 , and 5 .

- The UFA responded to simulated pumping in the LFA in a linear manner; that is, increases to the proposed withdrawal rate of 40 percent caused a 40-percent increase in drawdown. Similarly, the contribution of flow to the LFA from leakage from overlying units remained at 98 percent, and the contribution from lateral boundaries in the LFA was 2 percent for all simulations. Water managers at the State and municipal level could use these results to efficiently evaluate future withdrawal requests and determine offset pumpage reductions in the UFA necessary to alleviate drawdown in this unit that would be caused by the additional pumping in the LFA.
- Simulations run to address the leakage offset or drawdown offset of the Georgia Environmental Protection Division interim permitting strategy identified widely varying pumping offsets for the UFA, depending on whether the leakage or the drawdown offset for UFA pumping was evaluated. For example, when pumping the LFA at a rate of $780 \mathrm{gal} / \mathrm{min}$, the drawdown offset (255 $\mathrm{gal} / \mathrm{min}$ ) was nearly three times less than the leakage offset (762 gal/min).

- The effect of pumping redistribution on current groundwater conditions at Pooler was evaluated by incorporating a variety of pumping rates for LFA well 35Q069 and reducing pumping at existing Pooler supply wells by the computed UFA drawdown offsets. Simulations were run with the LFA pumped at rates of $780,1,042$, and $390 \mathrm{gal} / \mathrm{min}$ and corresponding decreases in UFA pumping of 255,340 , and $128 \mathrm{gal} / \mathrm{min}$. Each scenario resulted in decreased magnitude and extent of drawdown in the UFA when compared to scenarios with no discernible change in the configuration of the UFA potentiometric surface.

- Results of a sensitivity analysis of the calibrated model indicate that horizontal hydraulic conductivities $\left(\mathrm{K}_{\mathrm{h}}\right)$ of the UFA and LFA are the most important parameters in model simulations. Errors in these values would affect simulated maximum drawdown and associated drawdown offset computations.

- Increasing or decreasing $\mathrm{K}_{\mathrm{h}}$ and vertical hydraulic conductivity $\left(\mathrm{K}_{\mathrm{v}}\right)$ of hydrogeologic units had little effect on model specified-head and general head boundaries and on leakage. $\mathrm{K}_{\mathrm{h}}$ and $\mathrm{K}_{\mathrm{v}}$ of the Lower Floridan confining unit (LFCU) had little effect on simulated leakage and groundwater levels.

- Simulated rates of interaquifer leakage and drawdown in the UFA can differ from actual rates because of the influence of specified-head and general head boundaries, which supply an unlimited amount of water to the groundwater system. This unlimited supply may result in differences in simulated drawdown and rates of interaquifer leakage. Simulation results could be improved by replacing lateral specified-head boundaries with a natural boundary, such as a groundwater divide, and by using active simulation of the surficial aquifer. Simulation results have improved regional characterization of the Floridan aquifer system, which may be used by State officials in evaluating requests for groundwater withdrawal from the LFA. 


\section{Selected References}

Clarke, J.S., 2003, The surficial and Brunswick aquifer systems-Alternative ground-water resources for coastal Georgia, in Hatcher, K.J., ed., Proceedings of the 2003 Georgia Water Resources Conference, April 23-24, 2003, The University of Georgia, Institute of Ecology, Athens, Ga., CD-ROM.

Clarke, J.S., Hacke, C.M., and Peck, M.F., 1990, Geology and ground-water resources of the coastal area of Georgia: Georgia Geologic Survey Bulletin 113, 106 p.

Clarke, J.S., and Krause, R.E., 2000, Design, revision, and application of ground-water flow models for simulation of selected water-management scenarios in the coastal area of Georgia and adjacent parts of South Carolina and Florida: U.S. Geological Survey Water-Resources Investigations Report 00-4084, 93 p.

Clarke, J.S., Williams, L.J., and Cherry, G.C., 2010, Hydrogeology and water quality of the Floridan aquifer system and effect of Lower Floridan aquifer pumping on the Upper Floridan aquifer at Hunter Army Airfield, Chatham County, Georgia: U.S. Geological Survey Scientific Investigations Report 2010-5080, 56 p., available at http://pubs.usgs.gov/ sir/2010/5080/.

Clarke, J.S., Cherry, G.C., and Gonthier, G.J., 2011, Hydrogeology and water quality of the Floridan aquifer system and effects of Lower Floridan aquifer pumping on the Upper Floridan aquifer at Fort Stewart, Georgia: U.S. Geological Survey Scientific Investigations Report 2011-5065, 59 p., available at http://pubs.usgs.gov/sir/2011/5065/.

de Marsily, Ghislain, 1986, Quantitative hydrogeology: Orlando, Florida, Academic Press, Inc., 440 p.

Falls, W.F., Baum, J.S., Harrelson, L.G., Brown, L.H., and Jerden, J.L., Jr., 1997, Geology and hydrogeology of Cretaceous and Tertiary strata, and confinement in the vicinity of the U.S. Department of Energy Savannah River Site, South Carolina: U.S. Geological Survey WaterResources Investigations Report 97-4245, 125 p.

Fanning, J.L., and Trent, V.P., 2009, Water use in Georgia by county for 2005; and water-use trends, 1980-2005: U.S. Geological Survey Scientific Investigations Report 2009-5002, 186 p., available at http://pubs.usgs.gov/ sir/2009/5002/.

Georgia Department of Natural Resources, 2006, Coastal Georgia Water \& Wastewater Permitting Plan for Managing Salt Water Intrusion: Accessed September 7, 2012, at http://www1.gadnr.org/cws/Documents/saltwater management_plan_june2006.pdf.
Gonthier, G.J., 2011, Summary of hydrologic testing of the Floridan aquifer system at Fort Stewart, Liberty County, Georgia: U.S. Geological Survey Open-File Report 20111020, 40 p., available at http://pubs.usgs.gov/of/2011/1020/.

Gonthier, G.J., 2012, Hydrogeology and water quality of the Floridan aquifer system and effect of Lower Floridan aquifer pumping on the Upper Floridan aquifer, Pooler, Chatham County, Georgia, 2011-2012: U.S. Geological Survey Scientific Investigations Report 2012-5249, 62 p., available at $h t t p: / / p u b s . u s g s . g o v /$ sir/2012/5049/.

Halford, K.J., 2006, Documentation of a spreadsheet for timeseries analysis and drawdown estimation: U.S. Geological Survey Scientific Investigations Report 2006-5024, 38 p.

Harbaugh, A.W., 1990, A computer program for calculating subregional water budgets using results from the U.S. Geological Survey modular three-dimensional finite-difference ground-water flow model: U.S. Geological Survey Open-File Report 90-392, 46 p.

Hill, M.C., 1998, Methods and guidelines for effective model calibration: U.S. Geological Survey Water-Resources Investigation Report 98-4005, $90 \mathrm{p}$.

Krause, R.E., and Clarke, J.S., 2001, Coastal ground water at risk-Saltwater contamination at Brunswick, Georgia, and Hilton Head Island, South Carolina: U.S. Geological Survey Water-Resources Investigations Report 01-4107, accessed March 19, 2010, at http://ga2.er.usgs.gov/coastal/ coastalreport.cfm.

Krause, R.E., and Randolph, R.B., 1989, Hydrology of the Floridan aquifer system in southeast Georgia and adjacent parts of Florida and South Carolina: U.S. Geological Survey Professional Paper 1403-D, 65 p., 18 pl.

Miller, J.A., 1986, Hydrogeologic framework of the Floridan aquifer system in Florida and in parts of Georgia, Alabama, and South Carolina: U.S. Geological Survey Professional Paper 1403-B, 91 p., 33 pl.

Payne, D.F., Abu Rumman, Malek, and Clarke, J.S., 2005, Simulation of ground-water flow in coastal Georgia and adjacent parts of South Carolina and Florida-Predevelopment, 1980, and 2000: U.S. Geological Survey Scientific Investigations Report 2005-5089, 91 p., available at http://pubs.usgs.gov/sir/2005/5089/.

Peck, M.F., Clarke, J.S., Ransom, Camille, III, and Richards, C.J., 1999, Potentiometric surface of the Upper Floridan aquiferin Georgia and adjacent parts of Alabama, Florida, and South Carolina, May 1998, and water level-trends in Georgia, 1990-98: Georgia Geologic Survey Hydrologic Atlas 22, 1 sheet, scale 1:100,000, 1977-81. 
Randolph, R.B., Pernik, Maribeth, and Garza, Reggina, 1991, Water-supply potential of the Floridan aquifer system in the coastal area of Georgia-A digital model approach: Atlanta, Georgia Geologic Survey Bulletin 116, 30 p.

Southeast Regional Climate Center, 2010, Savannah WSO Airport, Georgia-Climate summary: Accessed September 3, 2010, at http://www.sercc.com/cgi-bin/ sercc/cliMAIN.pl?ga7847.

Weems, R.E., and Edwards, L.E., 2001, Geology of Oligocene, Miocene, and younger deposits in the coastal area of Georgia: Atlanta, Georgia Geologic Survey Bulletin 131, 124 p.
Williams, L.J., 2010, Summary of hydrologic testing of the Floridan aquifer system at Hunter Army Airfield, Chatham County, Georgia: U.S. Geological Survey OpenFile Report 2010-1066, 30 p., available at http://pubs.usgs. gov/of/2010/1066/.

Williams, L.J., and Gill, H.E., 2010, Revised hydrogeologic framework of the Floridan aquifer system in the northern coastal area of Georgia and adjacent parts of South Carolina: U.S. Geological Survey Scientific Investigations Report 2010-5158, 103 p., 3 pl., available at http://pubs. usgs.gov/sir/2010/5158/. 


\section{Appendix. Regional Groundwater Model}

A regional groundwater-flow model (herein referred to as "regional model") developed by Payne and others (2005) for the coastal region of Georgia and adjacent parts of South Carolina and Florida was modified and used to simulate the effects of pumping from the Lower Floridan aquifer at Pooler, Georgia. The regional model is described in detail in Payne and others (2005); a brief description is below.

The regional model uses MODFLOW-2000 (Harbaugh and others, 2000) to simulate flow in the surficial, Brunswick, and Floridan aquifer systems. To account for natural hydrologic boundaries, the model encompasses a 42,155 square mile $\left(\mathrm{mi}^{2}\right)$ area that includes the Coastal Plain of Georgia, northeastern Florida, southwestern South Carolina, and the adjacent offshore area (see fig. 1-1).

The regional model consists of the following seven model layers and corresponding hydrogeologic units (fig. 1-2) in descending order:

- Layer 1: Confined upper and lower water-bearing zones of the surficial aquifer system;

- Layer 2: Brunswick aquifer system confining unit;

- Layer 3: Upper and lower Brunswick aquifers, comprising the Brunswick aquifer system;

- Layer 4: Upper Floridan confining unit;

- Layer 5: Upper Floridan aquifer (UFA);

- Layer 6: Lower Floridan confining unit (LFCU); and

- Layer 7: Lower Floridan aquifer (LFA).

These units crop out to the northwest of the study area and generally dip and thicken to the southeast. The thickness, extent, and other hydraulic properties of these units, as well as the model development process, are described in detail in Payne and others (2005).

The regional model was discretized in the areal dimensions using a variably spaced grid and cell sizes ranging from approximately $4,000 \times 5,000$ feet $\left(\mathrm{ft} ; 0.7 \mathrm{mi}^{2}\right)$ to $16,500 \times 16,500 \mathrm{ft}\left(9.8 \mathrm{mi}^{2}\right)$. At Pooler, the mesh resolution was $14,900 \times 16,100 \mathrm{ft}$, requiring refinement for the current model application. Each hydrogeologic unit was represented with one layer of grid cells in the vertical dimension.
Lateral boundaries for all layers of the regional model were designated as no flow, with the exception of the southern and southwestern sides of layers 5, 6, and 7 (Upper and Lower Floridan aquifers and intervening confining unit), which were set as specified-head cells. Values assigned to specified-head cells were based on estimates of UFA head derived from the potentiometric-surface map for 1998 developed by Peck and others (1999).

The lowermost boundary of the regional model was designated as no flow, corresponding with the lower confining unit of the Floridan aquifer system; the uppermost boundary was set as a head-dependent flow (or general head) boundary, representing the confined zone of the surficial aquifer system (fig. 1-2). The general head boundary required a controlling specified-head and a conductance term to regulate groundwater flow between the top two layers of the model. The controlling head represented the water table in the onshore area and the freshwater equivalent of the saltwater head in the offshore area. In the onshore area, the conductance was set to limit the amount of recharge entering the system in any given grid cell for the 1980 and 2000 simulation periods to less-than-maximum recharge derived from baseflow estimates (Priest, 2004). The conductance established in the offshore area was set arbitrarily large, posing minimal resistance to flow in or out of the system, as little is known about hydraulic properties in this area.

Estimates of average annual pumpage were assigned in the regional model on the basis of county-aggregate and site-specific data. These data were used to develop pumpage distributions for the assumed steady-state conditions of 1980 and 2000 used for calibration. Pumpage was assigned to model layers 3 (Brunswick aquifer system), 5 (UFA), and 7 (LFA) on the basis of the open interval of wells. Pumping rates within a model cell were obtained by summing site-specific and nonsite-specific pumping rates corresponding to that model cell. Pumpage simulated by the model totaled 692 million gallons per day (Mgal/d) for 1980 and $798 \mathrm{Mgal} / \mathrm{d}$ for 2000 . Because pumpage during 2010 (799 Mgal/d) was about the same as in 2000, the revised model used to evaluate groundwater flow near Pooler was within the same range of calibrated pumping conditions as the regional model. 

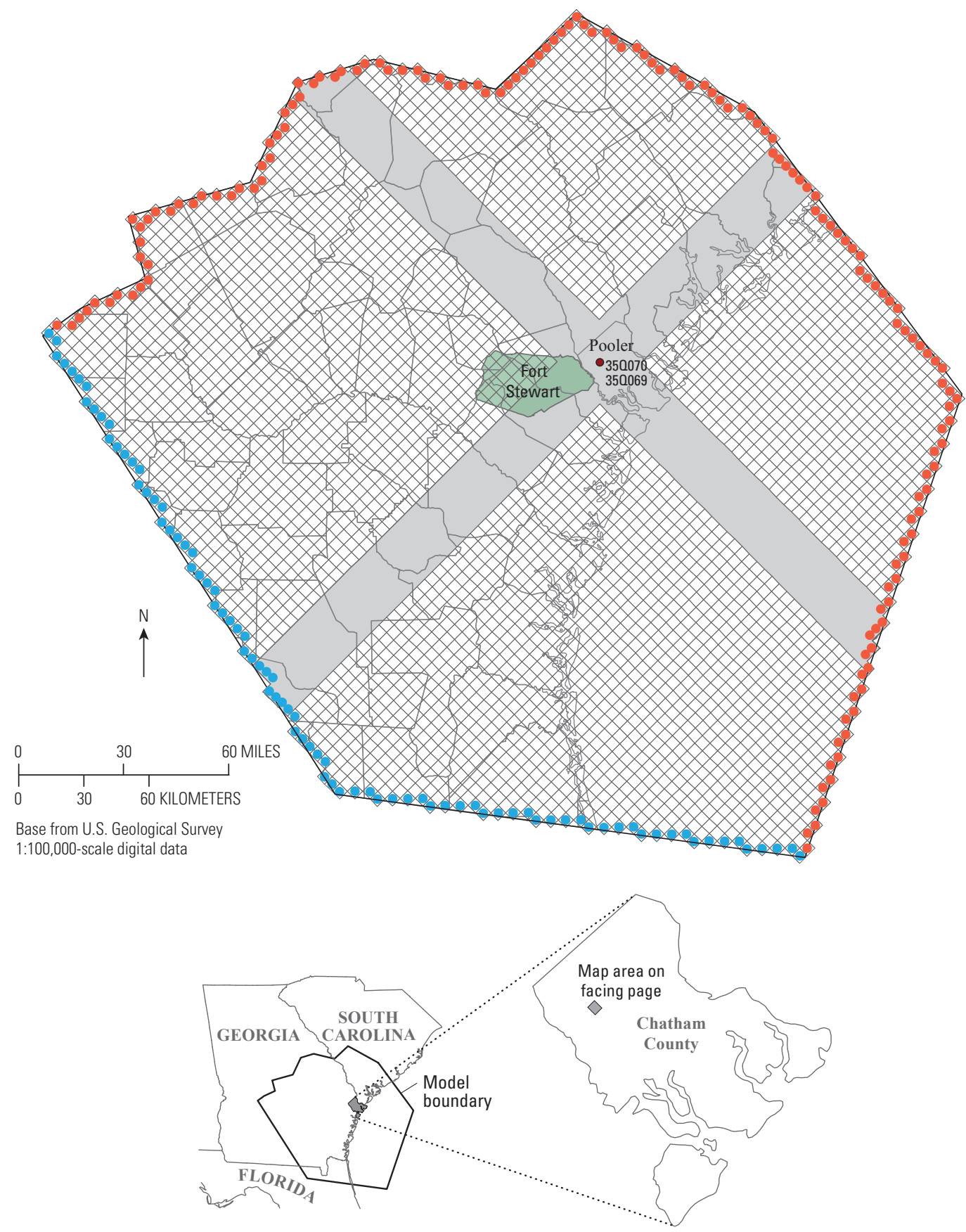

\section{EXPLANATION}

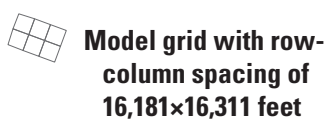
$16,181 \times 16,311$ feet
Area of dense model grid-

Row-column spacing ranges from $10 \times 10$ feet to $5,858 \times 5,397$ feet
Model boundary

- Specified head (model layers 5, 6, and 7)

- No-flow (all model layers)

Figure 1-1. Location of selected wells, regional groundwater model and boundary conditions, and revised model grid, City of Pooler, Fort Stewart, and vicinity, Georgia. 


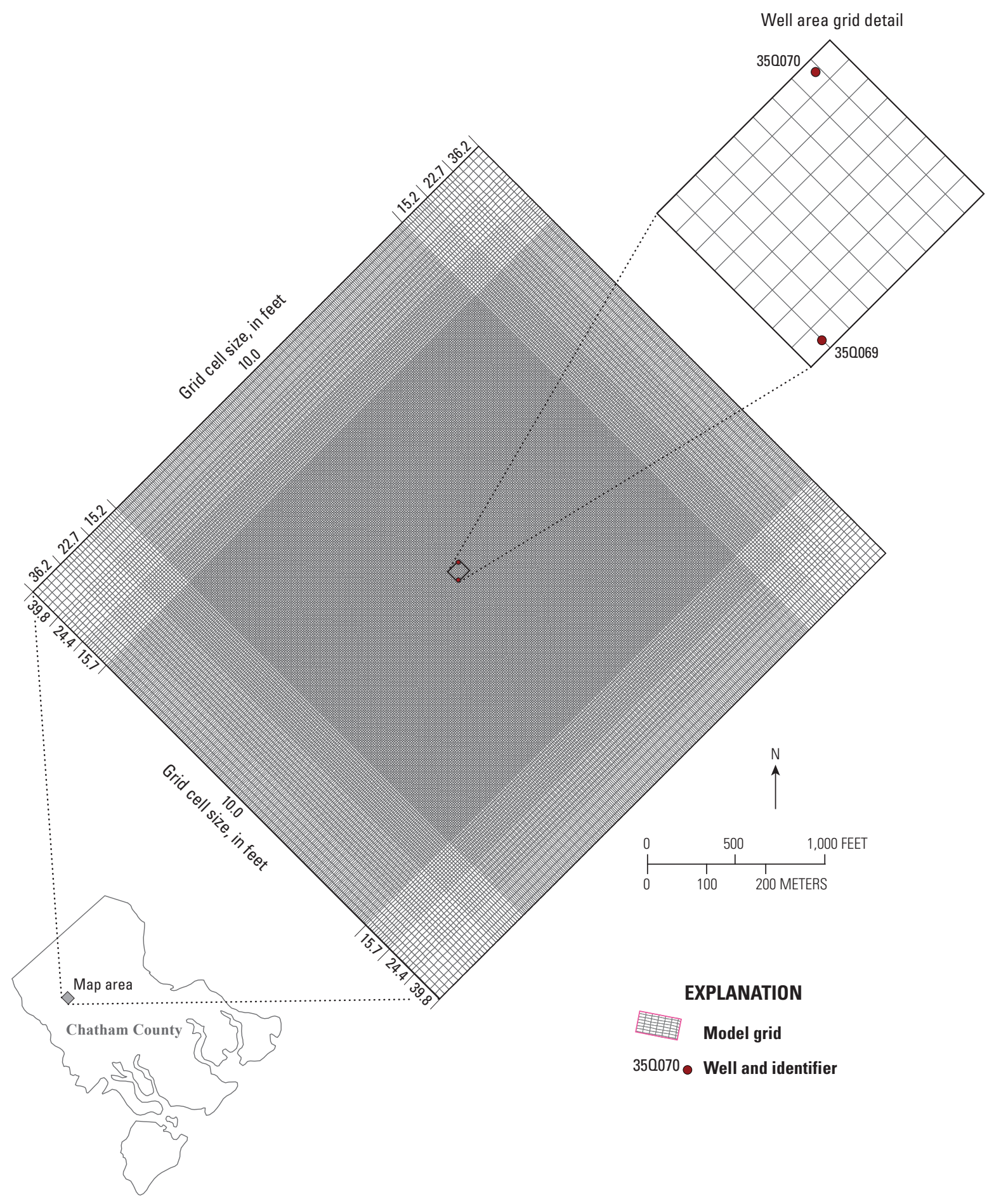

Figure 1-1. Location of selected wells, regional groundwater model and boundary conditions, and revised model grid, City of Pooler, Fort Stewart, and vicinity, Georgia.-Continued 


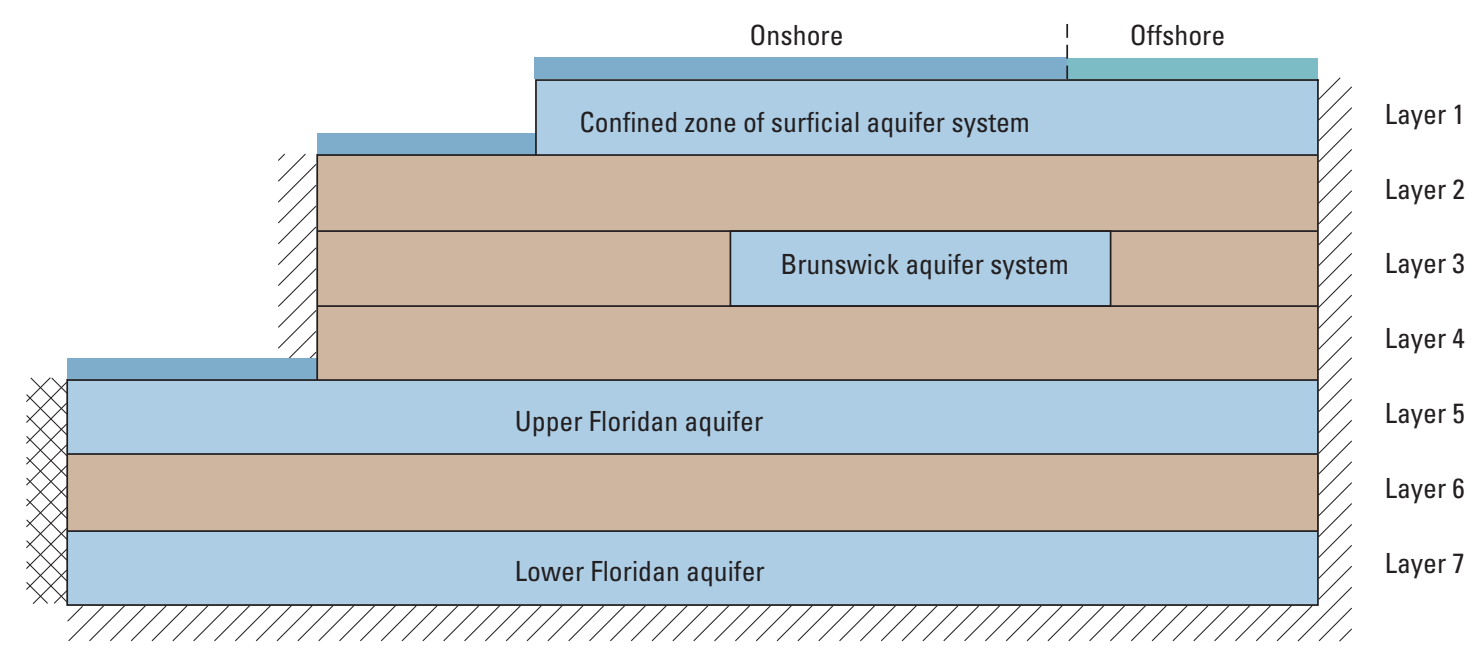

EXPLANATION

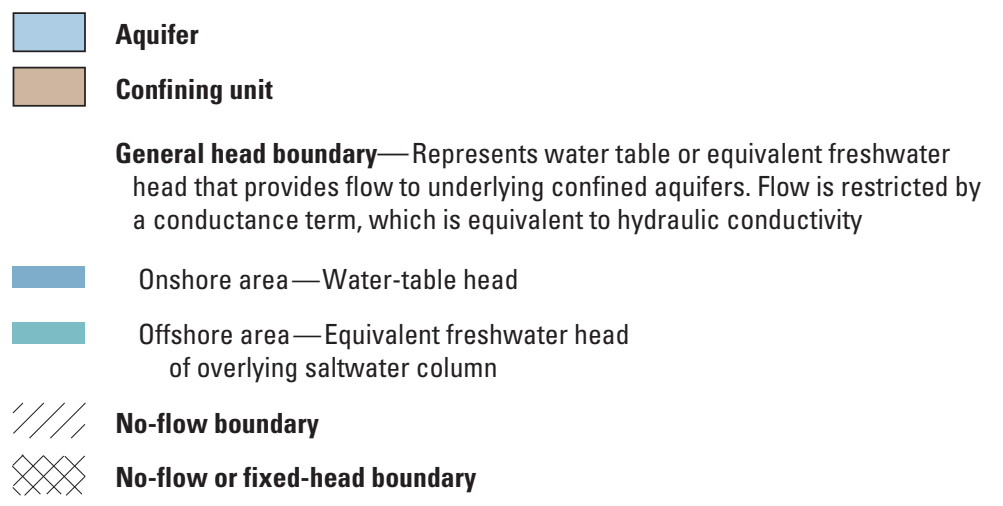

Figure 1-2. Schematic diagram showing model layers and boundary conditions (from Payne and others, 2005).

\section{Revisions to Regional Model}

The regional model of Payne and others (2005) was modified using hydrogeologic information obtained from field investigations at Pooler (Gonthier, 2012) and from existing wells in the vicinity of Hunter Army Airfield (HAAF; Clarke and others, 2010), at Fort Stewart (Clarke and others, 2011), and at Pooler. These modifications involved addition of new hydraulic-property zones for vertical and horizontal hydraulic conductivity in the Upper and Lower Floridan aquifers and intervening confining unit. Modifications to the regional model that were made during previous investigations at HAAF in Chatham County (Clarke and others, 2010) and Fort Stewart in Liberty County (Clarke and others, 2011) also were applied to the model developed for the current study. The revised model retained the original model layering and boundary conditions of the original regional model.

\section{Refinement of Grid Resolution}

Grid-cell dimensions were modified to variably spaced dimensions (fig. 1-1) that increase from the smallest cell size of $10 \mathrm{ft}$ by $10 \mathrm{ft}$ near well 35Q069 to a maximum size of about $16,181 \mathrm{ft}$ in the row direction and $16,311 \mathrm{ft}$ in the column direction. The orientation of the grid was rotated slightly in a clockwise fashion to accommodate the finer mesh in the Pooler area. The revised model consists of 440 rows and 424 columns. The variably spaced grid used in the revised model contains aspect ratios between row and column dimensions as large as 1,630:1, which can lead to numerical errors (de Marsily, 1986, p. 351). Fortunately, these large aspect ratio grid cells occur only in areas distant from Pooler and have little effect on simulation results in the area. 


\section{Refinement of Hydraulic Conductivity Distribution}

Packer-slug tests and core analyses performed at Pooler during the course of this study and in previous studies at HAAF and Fort Stewart provided the basis for revising hydraulic-conductivity values assigned to these areas in the regional model (Payne and others, 2005). In the area outside of Pooler, values of vertical and horizontal hydraulic conductivity ( $\mathrm{K}_{\mathrm{v}}$ and $\mathrm{K}_{\mathrm{h}}$, respectively) correspond to values used (1) in the regional model (Payne and others, 2005), (2) in the area of HAAF as simulated by Clarke and others (2010), and (3) in the area of Fort Stewart as simulated by Clarke and others (2011) (fig. 1-3; table 1-1). Field testing at Pooler (Gonthier, 2012) provided new information on the hydraulic properties of the UFA (layer 5), LFCU (layer 6), and LFA (layer 7) and enabled refinement of values that were used in the regional model. In addition, results of a 72 -hr aquifer test conducted in the LFA provided information on drawdown in the LFA and in the overlying UFA, which guided revisions to $\mathrm{K}_{\mathrm{v}}$ and $\mathrm{K}_{\mathrm{h}}$ values from previous calibrated values near Pooler.

New hydraulic-property zones were developed for this study on the basis of field data collected at Pooler (Gonthier, 2012), HAAF (Clarke and others, 2010), and Fort Stewart (Clarke and others, 2011). Zones were added as follows (fig. 1-3; table 1-1):

- UFA (layer 5) —zone F13 added at HAAF and expanded outward to include Pooler and zone F14 added at Fort Stewart,

- LFCU (layer 6) - zone LFC2 added at HAAF and expanded outward to include Pooler and zone LFC3 added at Fort Stewart, and

- LFA (layer 7)-zone LF2 added at HAAF and expanded outward to include Pooler and zone LF3 added at Fort Stewart.

The hydraulic-property zones for the HAAF and Fort Stewart models each encompass a $114-\mathrm{mi}^{2}$ area that includes the area of highest grid resolution and wells evaluated by model simulations (fig. 1-3). Each zone was initially assigned $\mathrm{K}_{\mathrm{h}}$ and $\mathrm{K}_{\mathrm{y}}$ values on the basis of results of field testing at each site. These values were adjusted slightly to calibrate waterlevel changes in the UFA and LFA observed during 72-hr aquifer tests at the two sites.

For the UFA (layer 5), zone F13 for the HAAF study (Clarke and others, 2010) was expanded from a 114- $\mathrm{mi}^{2}$ area to include Pooler and covered a 221- $\mathrm{mi}^{2}$ area. Here, the UFA was assigned $\mathrm{K}_{\mathrm{h}}$ and $\mathrm{K}_{\mathrm{y}}$ values of 90 feet per day ( $\mathrm{ft} / \mathrm{d}$ ) each, which is slightly higher than the $70 \mathrm{ft} / \mathrm{d}$ value assigned in the original regional model. Multiplying $90 \mathrm{ft} / \mathrm{d}$ by the thickness of the aquifer gives an estimated transmissivity of
44,000 feet squared per day $\left(\mathrm{ft}^{2} / \mathrm{d}\right)$ at Pooler, matching results of field testing reported by Gonthier (2012). For the revised model in the Fort Stewart area, zone F14 was subdivided from regional model zone $\mathrm{F} 5$ and assigned slightly higher $\mathrm{K}_{\mathrm{h}}$ and $\mathrm{K}_{\mathrm{v}}$ values of $398 \mathrm{ft} / \mathrm{d}$ each, which is based on results of aquifer testing (table 1-1). The new zone value of $398 \mathrm{ft} / \mathrm{d}$ represents a 1-percent increase from the $394 \mathrm{ft} / \mathrm{d}$ value assigned in the regional model (Payne and others, 2005) to zone F5. Multiplying $398 \mathrm{ft} / \mathrm{d}$ by the thickness of the aquifer gives an estimated transmissivity of $100,000 \mathrm{ft}^{2} / \mathrm{d}$, which matches the results of field testing (Gonthier, 2011).

In the regional model (Payne and others, 2005), the Lower Floridan confining unit (layer 6) was assigned a single $\mathrm{K}_{\mathrm{h}}$ and $\mathrm{K}_{\mathrm{v}}$ value of $0.02 \mathrm{ft} / \mathrm{d}$. Field data were used as a basis to delineate one additional zone at HAAF-Pooler and one additional zone at Fort Stewart. Values were initially assigned within the range of observed field values and adjusted during model calibration. At Fort Stewart, zone LFC3 in layer 6 covers an area identical to that of zone F14 in layer 5, with a calibrated $\mathrm{K}_{\mathrm{h}}$ value of 10 and a $\mathrm{K}_{\mathrm{v}}$ value of 0.2 ; these values are within the range of field testing (Gonthier, 2011).

In the vicinity of Pooler and HAAF, zone LFC2 in layer 6 covers an area of $221 \mathrm{mi}^{2}$, identical to that of zone F13 in layer 5, with a calibrated $K_{h}$ value of $2 \mathrm{ft} / \mathrm{d}$ and a $\mathrm{K}_{\mathrm{v}}$ value equal to $0.2 \mathrm{ft} / \mathrm{d}$ (fig. 1-3). These values are about 10 times higher than those assigned to the smaller $114.5-\mathrm{mi}^{2}$ zone F13 in the HAAF model (Clarke and others, 2010) but are still within the range of values derived from field testing (Gonthier, 2011, 2012).

Hydraulic properties for model layer 7, which represents the LFA, were designated as a single zone in the regional model of Payne and others (2005), having uniform $\mathrm{K}_{\mathrm{h}}$ and $\mathrm{K}_{\mathrm{v}}$ values of $10 \mathrm{ft} / \mathrm{d}$ each. Additional zones for the LFA were designated on the basis of field studies at Pooler, HAAF, and Fort Stewart. At Fort Stewart, zone LF3 covers an area identical to zones F14 and LFC3, containing a calibrated $\mathrm{K}_{\mathrm{h}}$ value of $15.8 \mathrm{ft} / \mathrm{d}$ and a $\mathrm{K}_{v}$ value of $1.6 \mathrm{ft} / \mathrm{d}$. Multiplying the $\mathrm{K}_{\mathrm{h}}$ value by the simulated thickness of the aquifer gives an estimated transmissivity of $5,200 \mathrm{ft}^{2} / \mathrm{d}$ at Fort Stewart, which is similar to results of field testing (Gonthier, 2011).

In the area of Pooler and HAAF, Zone LF2 in layer 7 for the HAAF study (Clarke and others, 2010) was expanded to include Pooler and covers a 221- $\mathrm{mi}^{2}$ area. Zone LF2 in layer 7 covers an area identical to zones F13 in layer 5 and LFC2 in layer 6 with a calibrated $\mathrm{K}_{\mathrm{h}}$ value of $88 \mathrm{ft} / \mathrm{d}$, a slight decrease from the calibrated HAAF model (Clarke and others, 2010). Multiplying the $\mathrm{K}_{\mathrm{h}}$ value by the simulated thickness of the aquifer gives an estimated transmissivity of $4,600 \mathrm{ft}^{2} / \mathrm{d}$, nearly the same as the $4,000-\mathrm{ft}^{2} / \mathrm{d}$ value derived from field testing at Pooler (Gonthier, 2012). 

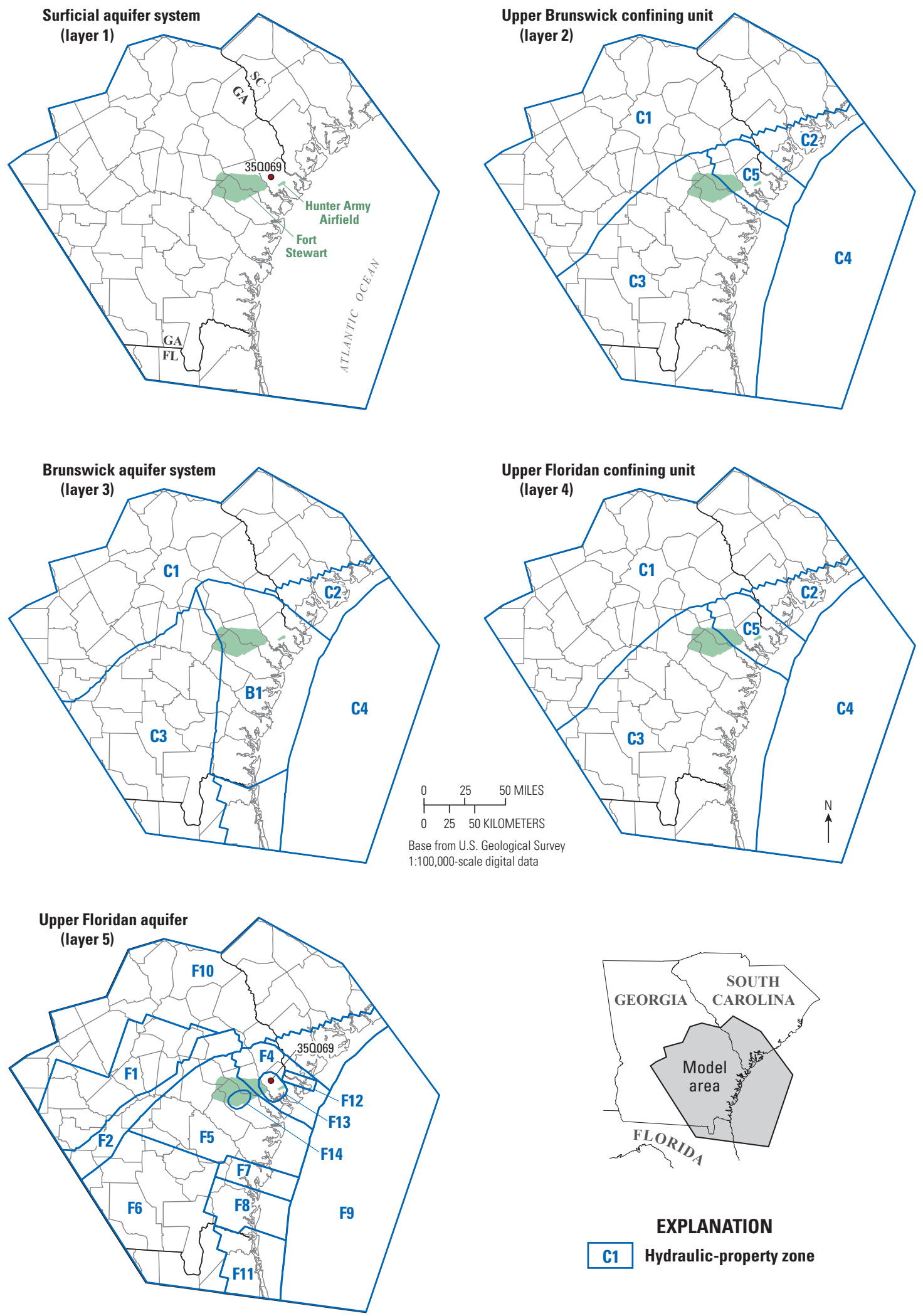

\section{EXPLANATION}

C1 Hydraulic-property zone

Figure 1-3. Simulated hydraulic-property zones by model layer. See table A-1 for hydraulic conductivity values assigned to zones. 
Figure 1-3. Simulated hydraulic-property zones by model layer. See table A-1 for hydraulic conductivity values assigned to zones.-Continued
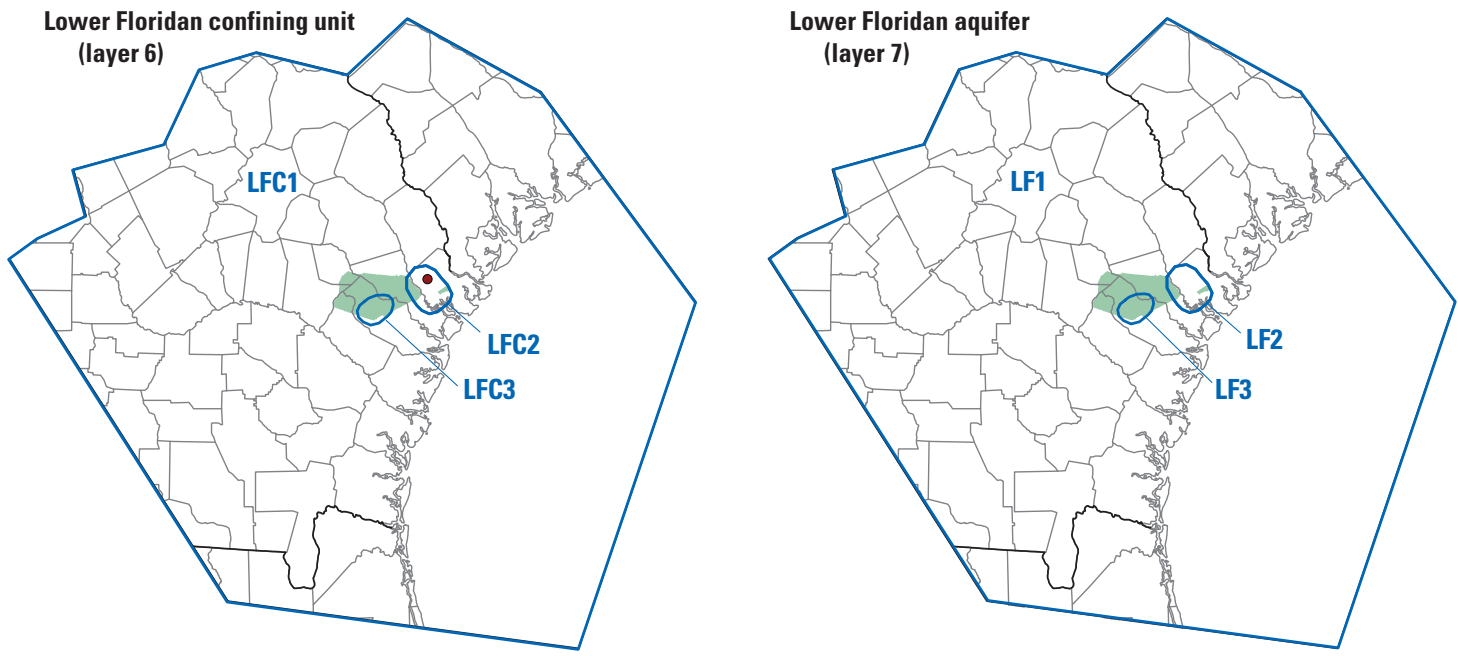

Table 1-1. Horizontal and vertical hydraulic conductivity values assigned to hydraulic-property zones for the original (Payne and others, 2005) and revised groundwater-flow models.

[—, not applicable]

\begin{tabular}{|c|c|c|c|c|c|c|c|}
\hline \multirow{3}{*}{ Unit } & \multirow{3}{*}{ Layer } & \multicolumn{3}{|c|}{ Payne and others, 2005} & \multicolumn{3}{|c|}{ Revised model } \\
\hline & & \multirow{2}{*}{$\begin{array}{c}\text { Hydaulic } \\
\text { property } \\
\text { zone }\end{array}$} & \multicolumn{2}{|c|}{$\begin{array}{l}\text { Hydraulic conductivity, } \\
\text { in feet per day }\end{array}$} & \multirow{2}{*}{$\begin{array}{c}\text { Hydaulic } \\
\text { property } \\
\text { zone }\end{array}$} & \multicolumn{2}{|c|}{$\begin{array}{l}\text { Hydraulic conductivity, } \\
\text { in feet per day }\end{array}$} \\
\hline & & & Horizontal & Vertical & & Horizontal & Vertical \\
\hline Surficial aquifer & 1 & - & 70 & 70 & 1 & 70 & 70 \\
\hline \multirow[t]{5}{*}{ Confining unit } & 2 & $\mathrm{C} 1$ & 0.00002 & 0.00002 & $\mathrm{C} 1$ & 0.00002 & 0.00002 \\
\hline & & $\mathrm{C} 2$ & 0.20000 & 0.20000 & $\mathrm{C} 2$ & 0.20000 & 0.20000 \\
\hline & & $\mathrm{C} 3$ & 0.00001 & 0.00001 & $\mathrm{C} 3$ & 0.00001 & 0.00001 \\
\hline & & $\mathrm{C} 4$ & 0.00010 & 0.00010 & $\mathrm{C} 4$ & 0.00010 & 0.00010 \\
\hline & & $\mathrm{C} 5$ & 0.00010 & 0.00010 & $\mathrm{C} 5$ & 0.00010 & 0.00010 \\
\hline \multirow[t]{5}{*}{ Brunswick aquifer system } & 3 & $\mathrm{~B} 1$ & 50 & 50 & B1 & 50 & 50 \\
\hline & & $\mathrm{C} 1$ & 0.00002 & 0.00002 & $\mathrm{C} 1$ & 0.00002 & 0.00002 \\
\hline & & $\mathrm{C} 2$ & 0.20000 & 0.20000 & $\mathrm{C} 2$ & 0.20000 & 0.20000 \\
\hline & & $\mathrm{C} 3$ & 0.00001 & 0.00001 & $\mathrm{C} 3$ & 0.00001 & 0.00001 \\
\hline & & $\mathrm{C} 4$ & 0.00010 & 0.00010 & $\mathrm{C} 4$ & 0.00010 & 0.00010 \\
\hline \multirow[t]{5}{*}{ Confining unit } & 4 & $\mathrm{C} 1$ & 0.00002 & 0.00002 & $\mathrm{C} 1$ & 0.00002 & 0.00002 \\
\hline & & $\mathrm{C} 2$ & 0.20000 & 0.20000 & $\mathrm{C} 2$ & 0.20000 & 0.20000 \\
\hline & & $\mathrm{C} 3$ & 0.00001 & 0.00001 & $\mathrm{C} 3$ & 0.00001 & 0.00001 \\
\hline & & $\mathrm{C} 4$ & 0.00010 & 0.00010 & $\mathrm{C} 4$ & 0.00010 & 0.00010 \\
\hline & & $\mathrm{C} 5$ & 0.00010 & 0.00010 & $\mathrm{C} 5$ & 0.00010 & 0.00010 \\
\hline \multirow[t]{14}{*}{ Upper Floridan aquifer } & 5 & $\mathrm{~F} 1$ & 34 & 34 & $\mathrm{~F} 1$ & 34 & 34 \\
\hline & & $\mathrm{F} 2$ & 2 & 2 & $\mathrm{~F} 2$ & 2 & 2 \\
\hline & & F3 & 100 & 100 & F3 & 100 & 100 \\
\hline & & F4 & 70 & 70 & F4 & 70 & 70 \\
\hline & & F5 & 394 & 394 & F5 & 394 & 394 \\
\hline & & F6 & 2,819 & 2,819 & F6 & 2,819 & 2,819 \\
\hline & & F7 & 150 & 150 & F7 & 150 & 150 \\
\hline & & F8 & 2,727 & 2,727 & F8 & 2,727 & 2,727 \\
\hline & & F9 & 100 & 100 & F9 & 100 & 100 \\
\hline & & F10 & 56 & 56 & F10 & 56 & 56 \\
\hline & & F11 & 94 & 94 & F11 & 94 & 94 \\
\hline & & F12 & 25 & 25 & F12 & 25 & 25 \\
\hline & & - & - & - & F13 & 90 & 90 \\
\hline & & - & - & - & F14 & 398 & 398 \\
\hline \multirow[t]{3}{*}{ Confining unit } & 6 & - & 0.02000 & 0.02000 & LFC1 & 0.02000 & 0.02000 \\
\hline & & - & - & - & LFC2 & 2.00000 & 0.2 \\
\hline & & - & - & - & LFC3 & 10.00000 & 0.2 \\
\hline \multirow[t]{3}{*}{ Lower Floridan aquifer } & 7 & - & 10.00000 & 1 & LF1 & 10 & 10 \\
\hline & & - & - & - & LF2 & 87 & 10 \\
\hline & & - & - & - & LF3 & 15.80000 & 1.6 \\
\hline
\end{tabular}




\section{Simulation of Observed Drawdown in Pumped Well}

Drawdown calculated by the revised model represents the average drawdown for a node located at the areal center of the grid cell containing the pumped well. This average drawdown under represents the observed drawdown in the actual pumped well 35Q069. Because the area of the grid cell containing the pumped well $\left(10 \mathrm{ft}^{2}\right)$ is much larger than the area defined by the 8 -inch well diameter $\left(0.35 \mathrm{ft}^{2}\right)$, drawdown at the pumped well can be adjusted on the basis of the proportional increase in area attributed to the grid cell in comparison with the area of the pumped well using the following equation (Peaceman, 1983):

$$
S_{p}=S_{b}+\left[Q \times \ln \left(r_{e} / r_{w}\right) / 2 \pi\left(T_{x x} T_{y y}\right) 0.5\right],
$$

where

$$
\begin{array}{cc}
S_{p} & \text { is adjusted drawdown in the pumped well, } \\
& \text { in feet; } \\
S_{b} & \text { is simulated drawdown in the pumped well, } \\
& \text { in feet; } \\
Q \quad & \text { is pump discharge, in cubic feet per day } \\
& (150,534) ; \\
r_{e} & \text { is equivalent well block radius, in feet (5); } \\
r_{w} & \text { is well radius, in feet (0.33); } \\
T_{x x} & \text { is transmissivity in the } x \text { direction, in } \\
& \quad \text { feet squared per day }(4,600) ; \text { and } \\
T_{y y} & \text { is transmissivity in the } y \text { direction, in } \\
& \text { feet squared per day }(4,600) .
\end{array}
$$

Results of this equation indicated that simulated values of drawdown at the center of the grid cell containing pumped well 35Q069 would under represent the observed drawdown by $14.2 \mathrm{ft}$ for a pumping rate of 780 gallons per minute ( $\mathrm{gal} / \mathrm{min}$ ). A similar analysis of an UFA well pumped at a rate of $205 \mathrm{gal} / \mathrm{min}$, having the same well radius as above but with a value of $44,000 \mathrm{ft}^{2} / \mathrm{d}$ for transmissivity, indicates that the simulated drawdown in the grid cell containing the pumped well under represents the observed drawdown at the pumped well by about $0.43 \mathrm{ft}$. Simulated drawdown for the UFA and LFA were adjusted using these correction factors and compared with observed data for model calibration.

\section{Comparison of Revised to Original Regional Model}

Because the regional model of Payne and others (2005) was modified by changing grid cell sizes and assigning different hydraulic properties in and near Pooler, a comparison of results from the two models ensures that the revised model is an accurate representation of groundwater flow. Simulation results indicate that water-level residuals and the water budget for the revised regional model are similar to the original model of Payne and others (2005), and thus, both models provide similar simulation of the hydrologic system (tables 1-2, 1-3). These results were expected because model revisions were limited to $114.5-$ and $221-\mathrm{mi}^{2}$ areas representing less than 1 percent of the model area.

Mean water-level residual for layer 3 (Brunswick aquifer system) shifted from a positive bias in the original model $(1.79 \mathrm{ft})$ to a negative bias in the revised model $(-2.68 \mathrm{ft})$, as shown on the residuals map and graphs (table 1-2;

figs. 1-4, 1-5). For layer 5 (UFA), the mean residual remained negative in the revised model, changing from $-0.84 \mathrm{ft}$ to $-2.37 \mathrm{ft}$. The mean residual for layer 7 (LFA) remained positive in the revised model but was closer to zero than the value from the original model, changing from $5.2 \mathrm{ft}$ to $2.18 \mathrm{ft}$. The root mean square (RMS) of residuals for layer 5 was similar for the original $(9.94 \mathrm{ft})$ and revised $(10.5 \mathrm{ft})$ models. For layer 7, the RMS of residuals decreased from $9.15 \mathrm{ft}$ in the regional model to $8.27 \mathrm{ft}$ in the revised model.

The RMS of water-level residuals for layer $3(10.3 \mathrm{ft})$ in the revised model is nearly double that of the original regional model $(5.91 \mathrm{ft})$ but is considered acceptable for the purpose of the modified model, which is to simulate flow in the UFA and LFA. Most of the increase in the RMS for layer 3 can be attributed to two wells in the Brunswick aquifer system that had water-level residuals of nearly $-19 \mathrm{ft}$ each (figs. 1-4, 1-5). These wells are located adjacent to one another in the same model cell, in an area where the grid size of the revised model is more than four times larger than in the original regional model. This larger grid size reduced the capability of the model to simulate steep gradients in the vicinity of the Savannah area cone of depression and resulted in a large residual. Because the relatively large grid size and related increase in RMS for layer 3 occurred away from the area of high grid resolution in the vicinity of Pooler, simulated heads in the Pooler area were only slightly affected. A comparison of simulated heads from six observation wells in model layer 5 located in northern Chatham County indicated heads computed by the revised model are about $1.5 \mathrm{ft}$ lower than those from the original model.

Simulated water budgets for the regional and revised models were similar with most variation occurring in layers 1 and 5 (table 1-3). The revised model showed a decrease in recharge from, and discharge to, the overlying general head boundary in layer 1 and increased outflow and inflow along lateral specified-head boundaries in layers 5 and 7 . 
Table 1-2. Water-level calibration statistics for the original (Payne and others, 2005) and revised regional models, year 2000 simulation. [Residual equals simulated minus observed head]

\begin{tabular}{|c|c|c|c|c|c|c|c|c|c|c|}
\hline \multirow{2}{*}{ Aquifer } & \multirow{2}{*}{$\begin{array}{l}\text { Model } \\
\text { layer }\end{array}$} & \multirow{2}{*}{$\begin{array}{l}\text { Number } \\
\text { of obser- } \\
\text { vations }\end{array}$} & \multicolumn{2}{|c|}{$\begin{array}{l}\text { Minimum residual, } \\
\text { in feet }\end{array}$} & \multicolumn{2}{|c|}{$\begin{array}{l}\text { Maximum residual, } \\
\text { in feet }\end{array}$} & \multicolumn{2}{|c|}{$\begin{array}{l}\text { Mean of residuals, } \\
\text { in feet }\end{array}$} & \multicolumn{2}{|c|}{$\begin{array}{l}\text { Root mean square of } \\
\text { residuals, in feet }\end{array}$} \\
\hline & & & $\begin{array}{c}\text { Original } \\
\text { model }\end{array}$ & $\begin{array}{l}\text { Revised } \\
\text { model }\end{array}$ & $\begin{array}{c}\text { Original } \\
\text { model }\end{array}$ & $\begin{array}{l}\text { Revised } \\
\text { model }\end{array}$ & $\begin{array}{c}\text { Original } \\
\text { model }\end{array}$ & $\begin{array}{l}\text { Revised } \\
\text { model }\end{array}$ & $\begin{array}{c}\text { Original } \\
\text { model }\end{array}$ & $\begin{array}{c}\text { Revised } \\
\text { model }\end{array}$ \\
\hline Brunswick aquifer system & 3 & 10 & -7.67 & -18.8 & 13.3 & 10.4 & 1.79 & -2.68 & 5.91 & 10.3 \\
\hline Upper Floridan aquifer & 5 & 155 & -44.4 & -29.8 & 36.4 & 35.0 & -0.84 & -2.37 & 9.94 & 10.5 \\
\hline Lower Floridan aquifer & 7 & 11 & -3.62 & -5.70 & 21.5 & 23.0 & 5.2 & 2.18 & 9.15 & 8.27 \\
\hline
\end{tabular}

Table 1-3. Comparison of simulated water budget by model layer between the original (Payne and others, 2005) and revised regional models, year 2000 simulation.

[Values reported to three significant digits and may not sum to totals because of independent rounding; $<$, less than]

\begin{tabular}{|c|c|c|c|c|c|c|c|c|c|c|c|}
\hline \multirow{3}{*}{$\begin{array}{l}\text { Hydro- } \\
\text { geologic } \\
\text { unit }\end{array}$} & \multirow{3}{*}{$\begin{array}{l}\text { Model } \\
\text { layer }\end{array}$} & \multicolumn{10}{|c|}{ Simulated flow, in million gallons per day } \\
\hline & & \multicolumn{2}{|c|}{ Pumpage } & \multicolumn{2}{|c|}{$\begin{array}{c}\text { Recharge from } \\
\text { general head } \\
\text { boundary }\end{array}$} & \multicolumn{2}{|c|}{$\begin{array}{l}\text { Discharge to } \\
\text { general head } \\
\text { boundary }\end{array}$} & \multicolumn{2}{|c|}{$\begin{array}{l}\text { Inflow along } \\
\text { lateral boundary }\end{array}$} & \multicolumn{2}{|c|}{$\begin{array}{l}\text { Outflow along } \\
\text { lateral boundary }\end{array}$} \\
\hline & & $\begin{array}{l}\text { Original } \\
\text { model }\end{array}$ & Revised & $\begin{array}{c}\text { Original } \\
\text { model }\end{array}$ & Revised & $\begin{array}{l}\text { Original } \\
\text { model }\end{array}$ & Revised & $\begin{array}{c}\text { Original } \\
\text { model }\end{array}$ & Revised & $\begin{array}{c}\text { Original } \\
\text { model }\end{array}$ & Revised \\
\hline $\begin{array}{l}\text { Surficial } \\
\text { aquifer } \\
\text { system }\end{array}$ & 1 & $<0.001$ & $<0.001$ & 310 & 280 & 132 & 106 & $<0.001$ & $<0.001$ & $<0.001$ & $<0.001$ \\
\hline $\begin{array}{l}\text { Confining } \\
\text { unit }\end{array}$ & 2 & $<0.001$ & $<0.001$ & 46.6 & 45.4 & 3.62 & 5.72 & $<0.001$ & $<0.001$ & $<0.001$ & $<0.001$ \\
\hline $\begin{array}{c}\text { Brunswick } \\
\text { aquifer } \\
\text { system }\end{array}$ & 3 & 0.241 & 0.241 & $<0.001$ & $<0.001$ & $<0.001$ & $<0.001$ & $<0.001$ & $<0.001$ & $<0.001$ & $<0.001$ \\
\hline $\begin{array}{l}\text { Confining } \\
\text { unit }\end{array}$ & 6 & $<0.001$ & $<0.001$ & $<0.001$ & $<0.001$ & $<0.001$ & $<0.001$ & 0.004 & 0.005 & $<0.001$ & $<0.001$ \\
\hline $\begin{array}{l}\text { Lower } \\
\text { Floridan } \\
\text { aquifer }\end{array}$ & 7 & 129 & 129 & $<0.001$ & $<0.001$ & $<0.001$ & $<0.001$ & 15.5 & 17.9 & 2.32 & 2.69 \\
\hline $\begin{array}{l}\text { Total all } \\
\text { layers }\end{array}$ & & 798 & 798 & 498 & 467 & 158 & 134 & 728 & 780 & 270 & 318 \\
\hline
\end{tabular}




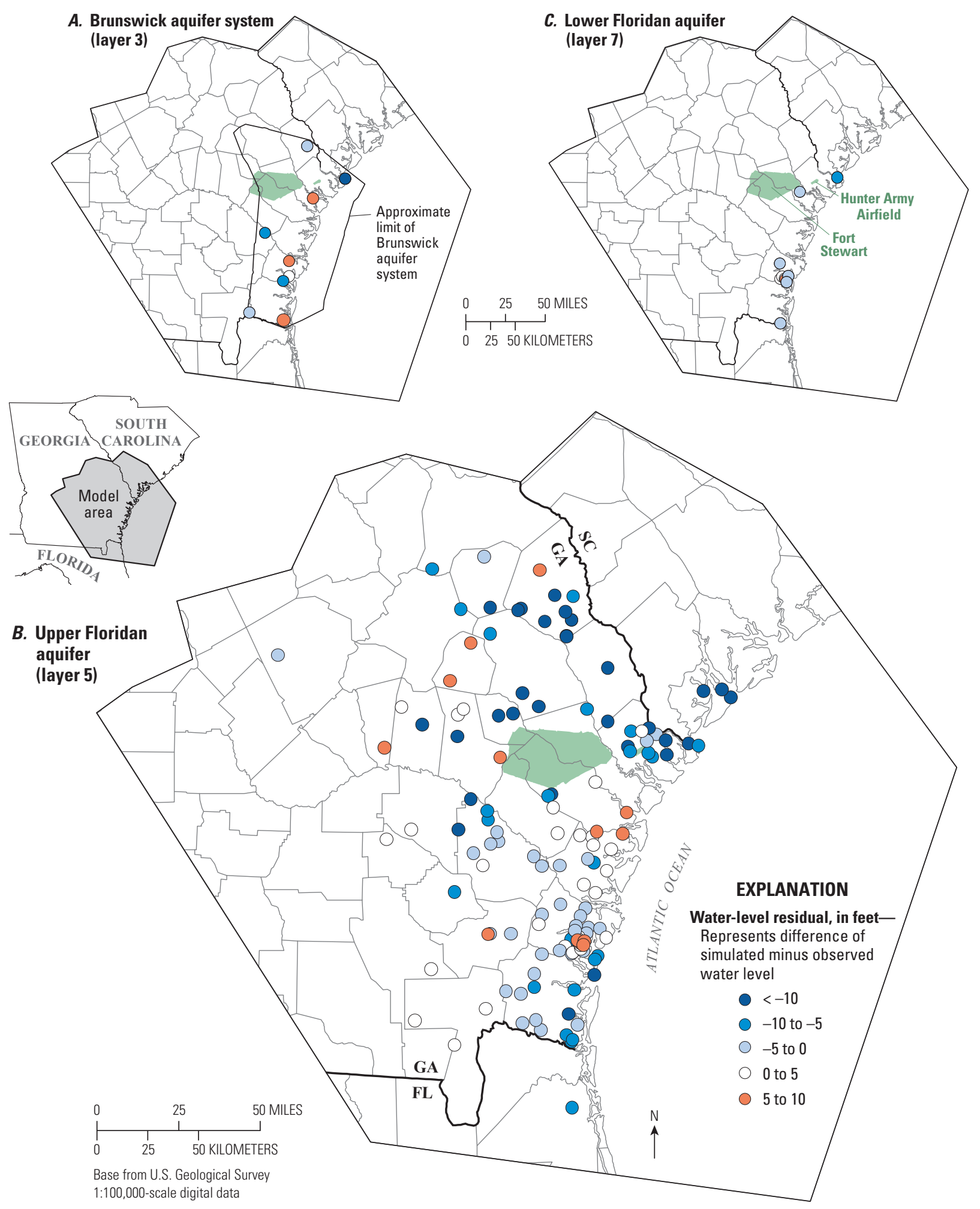

Figure 1-4. Difference between simulated and observed water levels (residuals) by model layer for 2000, revised regional flow model. $A$, Brunswick aquifer system (layer 3). $B$, Upper Floridan aquifer (layer 5). $C$, Lower Floridan aquifer (layer 7). 

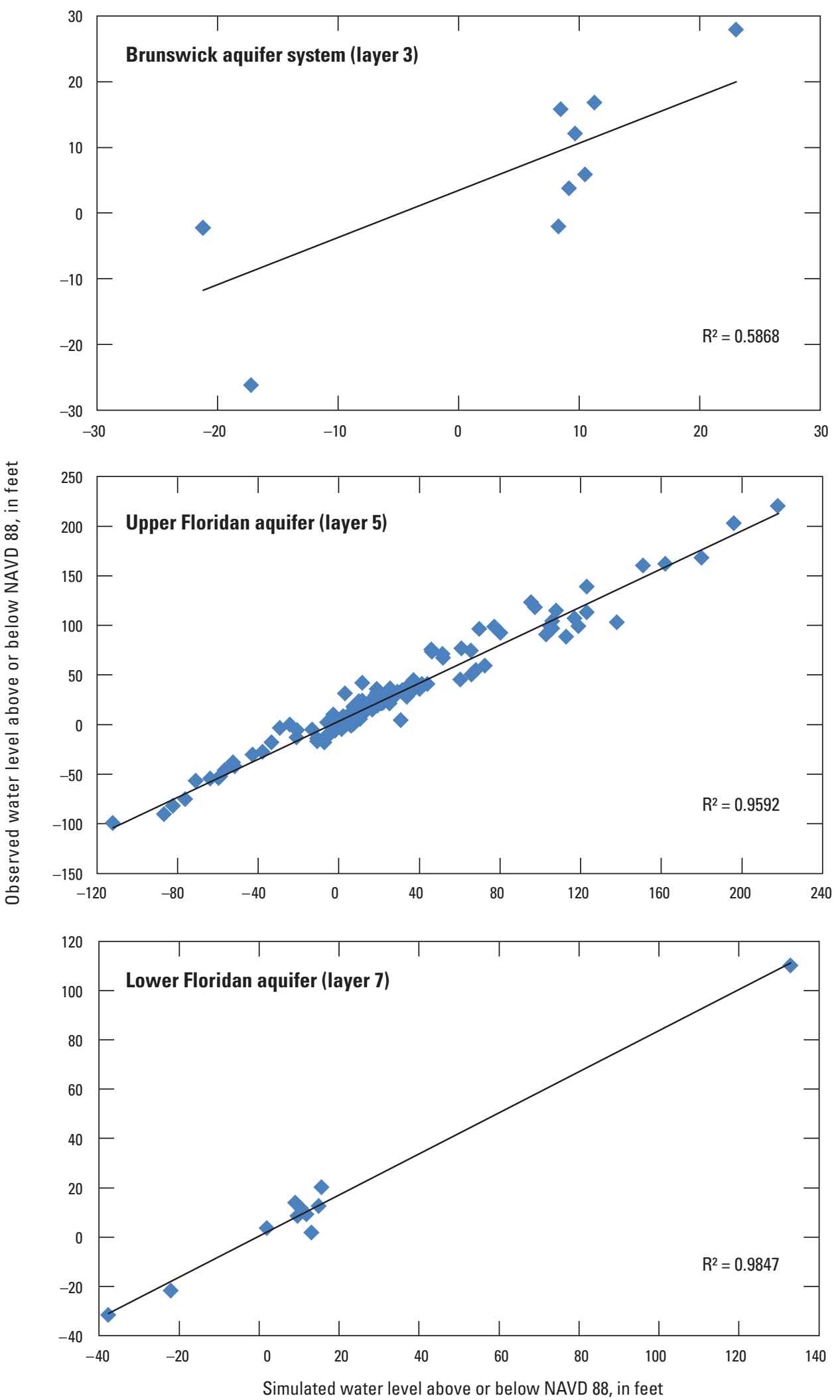

Figure 1-5. Observed and simulated water levels in model layers 3, 5, and 7, revised groundwater model. 


\section{References Cited}

Clarke, J.S., Williams, L.J., and Cherry, G.C., 2010, Hydrogeology and water quality of the Floridan aquifer system and effect of Lower Floridan aquifer pumping on the Upper Floridan aquifer at Fort Stewart, Chatham County, Georgia: U.S. Geological Survey Scientific Investigations Report 2010-5080, 56 p., available at http://pubs.usgs.gov/ sir/2010/5080/.

Clarke, J.S., Cherry, G.C., and Gonthier, G.J., 2011, Hydrogeology and water quality of the Floridan aquifer system and effects of Lower Floridan aquifer pumping on the Upper Floridan aquifer at Fort Stewart, Georgia: U.S. Geological Survey Scientific Investigations Report 2011-5065, 59 p., available at http://pubs.usgs.gov/sir/2011/5065/.

de Marsily, Ghislain, 1986, Quantitative hydrogeology: Orlando, Florida, Academic Press, Inc., 440 p.

Gonthier, G.J., 2011, Summary of hydrologic testing of the Floridan aquifer system at Fort Stewart, Georgia: U.S. Geological Survey Open-File Report 2011-1020, 28 p., available at http://pubs.usgs.gov/of/2011/1020/.

Gonthier, G.J., 2012, Hydrogeology and water quality of the Floridan aquifer system and effect of Lower Floridan aquifer pumping on the Upper Floridan aquifer, Pooler, Chatham County, Georgia, 2011-2012: U.S. Geological Survey Scientific Investigations Report 2012-5249, 62 p., available at http://pubs.usgs.gov/sir/2012/5049/.
Harbaugh, A.W., Banta, E.R., Hill, M.C., and McDonald, M.G., 2000, MODFLOW-2000, The U.S. Geological Survey modular ground-water model-User guide to modularization concepts and the ground-water flow process: U.S. Geological Survey Open-File Report 00-92, 121 p., available at http://water.usgs.gov/nrp/gwsoftware/ modflow2000/ofr00-92.pdf.

Payne, D.F., Abu Rumman, Malek, and Clarke, J.S., 2005, Simulation of ground-water flow in coastal Georgia and adjacent parts of South Carolina and Florida-Predevelopment, 1980, and 2000: U.S. Geological Survey Scientific Investigations Report 2005-5089, 91 p., available at http://pubs.usgs.gov/sir/2005/5089/.

Peaceman, D.W., 1983, Interpretation of well-block pressures in numerical reservoir simulation with nonsquare grid blocks and anisotropic permeability: Society of Petroleum Engineers Journal, v. 23, no. 3, p. 531-543.

Peck, M.F., Clarke, J.S., Ransom, Camille, III, and Richards, C.J., 1999, Potentiometric surface of the Upper Floridan aquifer in Georgia and adjacent parts of Alabama, Florida, and South Carolina, May 1998, and water leveltrends in Georgia, 1990-98: Georgia Geologic Survey Hydrologic Atlas 22, 1 sheet.

Priest, Sherlyn, 2004, Stream-aquifer relations in the coastal area of Georgia and adjacent parts of Florida and South Carolina: Georgia Geologic Information Circular 108, 40 p. 
Manuscript approved on January 4, 2013

Edited by Ruth Larkins, West Trenton PSC Illustrations and layout by Caryl J. Wipperfurth, Raleigh PSC

Science Publishing Network

For more information about this publication, contact: USGS Georgia Water Science Center 3039 Amwiler Road

Atlanta, GA 30360

telephone: 770-903-9100

http://ga.water.usgs.gov/ 
